\title{
Satellite perspective of aerosol intercontinental transport: From qualitative tracking to quantitative characterization
}

\author{
Hongbin $\mathrm{Yu}^{\mathrm{a}, \mathrm{b}, *}$, Lorraine A. Remer ${ }^{\mathrm{c}}$, Ralph A. Kahn ${ }^{\mathrm{b}}$, Mian Chin ${ }^{\mathrm{b}}$, Yan Zhang ${ }^{\mathrm{b}, \mathrm{d}}$ \\ a Earth System Science Interdisciplinary Center, University of Maryland, College Park, MD, 20740, USA \\ b Earth Science Directorate, NASA Goddard Space Flight Center, Greenbelt, MD, 20771, USA \\ c Joint Center for Earth Systems Technology, University of Maryland at Baltimore County, Baltimore, MD, 21228, USA \\ d Universities Space Research Association, Columbia, MD, 21044, USA
}

\section{A R T I C L E I N F O}

\section{Article history:}

Received 29 June 2012

Received in revised form 21 November 2012

Accepted 18 December 2012

Available online 11 January 2013

\section{Keywords:}

Aerosols

Particulate matter

Satellite remote sensing

Long-range transport

\begin{abstract}
A B S T R A C T
Evidence of aerosol intercontinental transport (ICT) is both widespread and compelling. Model simulations suggest that ICT could significantly affect regional air quality and climate, but the broad inter-model spread of results underscores a need of constraining model simulations with measurements. Satellites have inherent advantages over in situ measurements to characterize aerosol ICT, because of their spatial and temporal coverage. Significant progress in satellite remote sensing of aerosol properties during the Earth Observing System (EOS) era offers the opportunity to increase quantitative characterization and estimates of aerosol ICT beyond the capability of pre-EOS era satellites that could only qualitatively track aerosol plumes. EOS satellites also observe emission strengths and injection heights of some aerosols, aerosol precursors, and aerosol-related gases, which can help characterize aerosol ICT. We review how the current generation of satellite measurements have been used to (1) characterize the evolution of aerosol plumes (e.g., both horizontal and vertical transport, and properties) on an episodic basis, (2) understand the seasonal and inter-annual variations of aerosol ICT and their control factors, (3) estimate the export and import fluxes of aerosols, and (4) evaluate and constrain model simulations. Substantial effort is needed to further explore an integrated approach using measurements from on-orbit satellites (e.g., A-Train synergy) for observational characterization and model constraint of aerosol intercontinental transport and to develop advanced sensors for future missions.
\end{abstract}

(c) 2013 Elsevier B.V. All rights reserved.

\section{Contents}

1. Introduction . . . . . . . . . . . . . . . . . . . . . . . . . . . . 74

1.1. Aerosol intercontinental transport and its environmental impacts . . . . . . . . . . . . . . . . . . . . . . . . 74

1.2. Measurement needs for assessing aerosol intercontinental transport . . . . . . . . . . . . . . . . . . . . . . . 75

2. Satellite characterization of aerosol intercontinental transport . . . . . . . . . . . . . . . . . . . . . 77

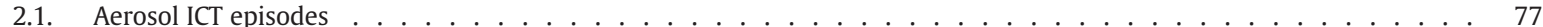

2.1.1. Tracking plumes . . . . . . . . . . . . . . . . . . . . . . . . . 77

2.1.2. Quantifying aerosol loading . . . . . . . . . . . . . . . . . . . . . . . . . 78

2.1.3. Quantifying aerosol particle properties . . . . . . . . . . . . . . . . . . . . 81

2.1.4. Characterizing aerosol vertical distributions . . . . . . . . . . . . . . . . . . . . . . . . . . . . . . 81

\footnotetext{
* Corresponding author at: Climate and Radiation Laboratory, NASA GSFC Code 613, Greenbelt, MD 20771, USA. Tel.: + 13016146209 ; fax: + 13016146307. E-mail addresses: Hongbin.Yu@nasa.gov, Hongbin.Yu@gmail.com (H. Yu).
} 
2.2. Aerosol ICT climatology . . . . . . . . . . . . . . . . . . . . . . . . . . . . 83

2.2.1. Intra-seasonal and seasonal variations . . . . . . . . . . . . . . . . . . . . . . . . . . . . . . . . . . 83

2.2.2. Inter-annual variations . . . . . . . . . . . . . . . . . . . . . . . . . . . . . . . . . . . . 85

3. Satellite estimates of aerosol export and import mass flux . . . . . . . . . . . . . . . . . . . . . . . . . . 85

3.1. Recent progress . . . . . . . . . . . . . . . . . . . . . . . . . . . 85

3.2. Limitations and outlook . . . . . . . . . . . . . . . . . . . . . . . . . . . . . 8 87

4. Satellite evaluation and constraints on model simulations . . . . . . . . . . . . . . . . . . . . . . . . . . 88

4.1. Source characterization . . . . . . . . . . . . . . . . . . . . . . . . . . 88

4.2. Model evaluation . . . . . . . . . . . . . . . . . . . . . . . . . . . . 89

4.3. Integrated approach . . . . . . . . . . . . . . . . . . . . . . . . . 90

5. Conclusions and outlook . . . . . . . . . . . . . . . . . . . . . . . . . . . . .

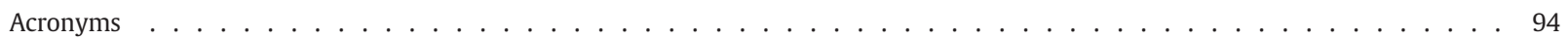

Acknowledgments . . . . . . . . . . . . . . . . . . . . . . . . . . . . 94

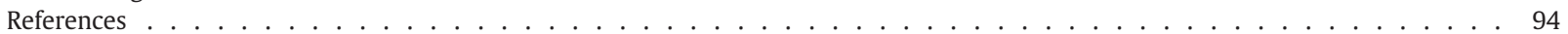

\section{Introduction}

\subsection{Aerosol intercontinental transport and its environmental} impacts

Atmospheric aerosols are solid or liquid particles suspended in the atmosphere that exert important influences on the environment. They are emitted directly into the atmosphere as primary aerosols, or are secondary aerosols, formed through chemical transformations from a variety of natural and manmade gaseous emissions. They exhibit great variability not only in concentration but also in size, composition, and shape. Aerosols are removed from the atmosphere through gravitational settling, dry deposition, and wet scavenging, processes that typically produce lifetimes of hours to days in the atmospheric boundary layer and of weeks in the upper troposphere. Thus aerosols emitted from one continent are often transported long distances to another, in particular when aerosols are pumped out of the boundary layer. There is mounting evidence for intercontinental and even hemispheric transport, provided by long-term surface monitoring networks, in-situ measurements from intensive field campaigns, and especially satellite observation, supported by model simulations. For example, it was determined that the recurring phenomenon of "Arctic haze" in late winter and early spring is associated mainly with long-range transport of pollution and dust sources in Europe and Asia (Rahn et al., 1977; Shaw, 1983). Saharan dust routinely reaches the Amazon, the Caribbean Sea and southeastern U.S. after sweeping over the Atlantic Ocean (Swap et al., 1992; Prospero, 1999; Prospero et al., 2005). Asian dust and pollution have long been observed in the western U.S. and beyond (Jaffe et al., 1999; Biscaye et al., 2000; VanCuren and Cahill, 2002; Grousset et al., 2003; Stohl et al., 2007). Microorganisms such as bacteria, fungi, and viruses can be transported along with dust aerosol (Griffin, 2007), raising additional health concern.

Because of the long-range transport, aerosols emitted or formed in one region could exert significant environmental changes in downwind regions/continents. In high concentrations, aerosol, also known as particulate matter or PM, can be harmful to human health (Pope et al., 2002). Aerosols affect weather and climate by scattering and absorbing solar radiation (so-called "aerosol direct effects") (McCormick and Ludwig,
1967) and by modifying cloud properties, amount, and evolution (collectively referred to as "aerosol indirect effects") (Twomey, 1977; Gunn and Philips, 1957; Albrecht, 1989). Absorption of solar radiation by particles can alter the atmospheric stability structure and reduce the surface flux, which can change atmospheric circulations (Yu et al., 2002; Ramanathan et al., 2005; Lau and Kim, 2006; Lau et al., 2009; Zhang et al., 2009). Dust aerosol rich in iron affects climate indirectly by changing biogeochemistry (Jickells et al., 2005). Near-surface aerosol also impairs visibility (White, 1976) and can affect crop yields (Chameides et al., 1999). All these effects depend on aerosol composition or type. As such, the long-range transport of air pollution has been an active topic of scientific research for several decades and has also been debated for formulating environmental policies and treaties (Holloway et al., 2003). One of the most recent coordinated efforts is the establishment of the Task Force on Hemispheric Transport of Air Pollutants (HTAP) by the United Nations Economic Commission for Europe, aiming to understand the growing body of scientific evidence of intercontinental transport and assess its impacts on air quality, climate, and ecosystems (HTAP, 2010).

Impacts of aerosol intercontinental transport (ICT) on regional air quality and climate change are potentially large, as estimated by global chemical transport models (CTM) (HTAP, 2010); however, large uncertainties are associated with the ensemble CTMs employed in the assessment. A CTM is a flexible tool to study how atmospheric aerosol concentrations in a receptor region (e.g., a continent) will change in response to a change of emissions in an upwind source region, an analysis broadly referred to as source-receptor relationship experiment. The relative annual intercontinental response (RAIR) metric was recently introduced to measure the percentage contribution of the intercontinental transport of foreign emissions relative to the sum of foreign and domestic emissions in a specific continent/region (HTAP, 2010). Fig. 1 shows RAIR for surface PM concentration, a quantity related to air quality, and aerosol optical depth (AOD), a quantity related to aerosol climate forcing. The RAIR is calculated from the HTAP sourcereceptor relationship experiments of multiple global aerosol models, in which anthropogenic emissions in each of the four major industrial regions (North America - NA, Europe - EU, East Asia - EA, and South Asia - SA) are reduced by 20\% (HTAP, 2010; Yu et al., 2013). For example, an RAIR value of 0.1 for AOD 
(a) RAIR for surface PM (sulfate+POM) concentration

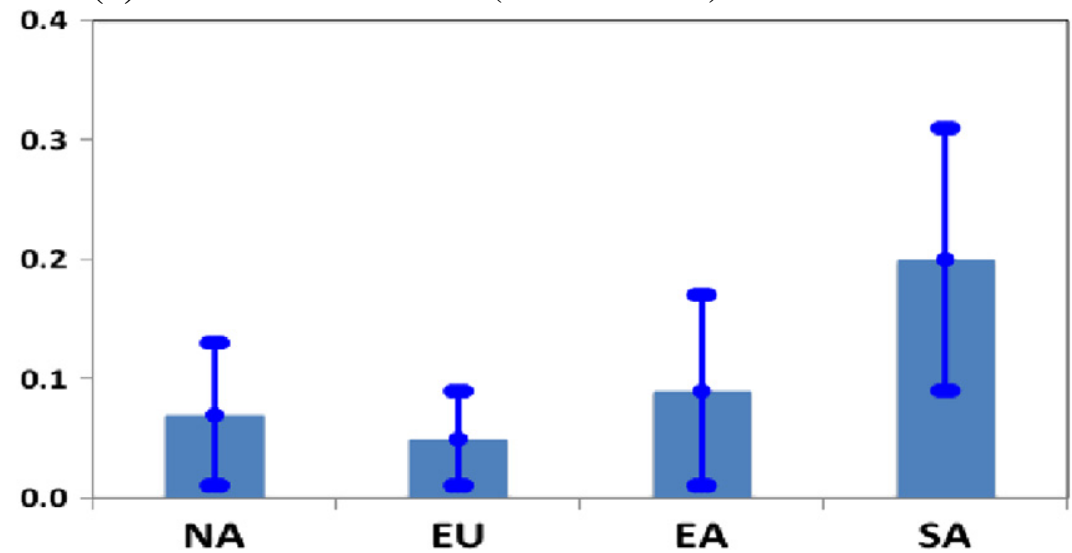

(b) RAIR for AOD

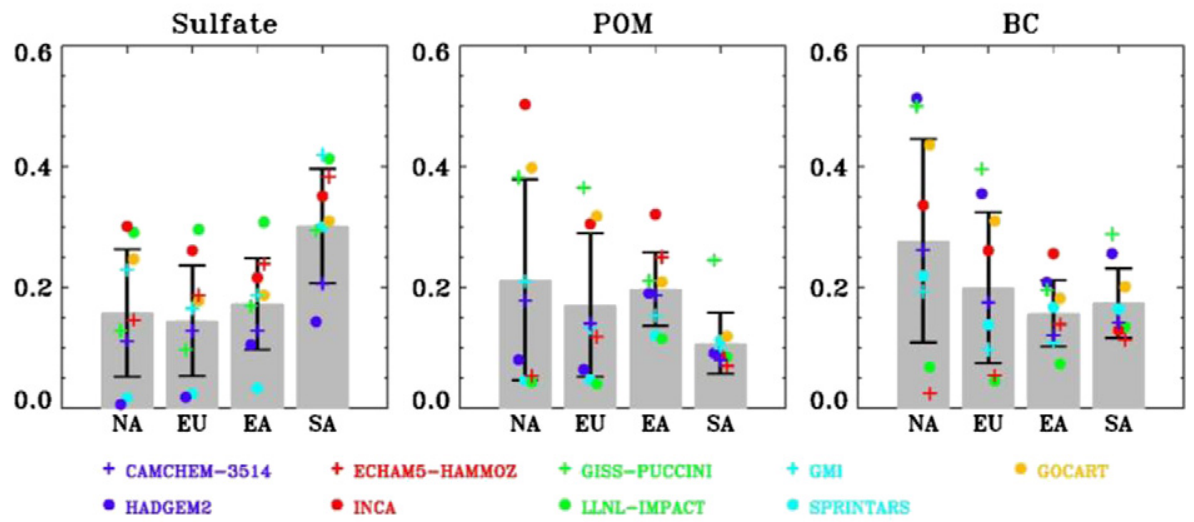

Fig. 1. Multi-model derived average relative annual intercontinental response (RAIR) for surface concentration of $\mathrm{SO}_{4}+\mathrm{POM}(\mathrm{a})$ and aerosol optical depth (AOD) (b) by chemical component in four major pollution regions (NA - North America, EU - Europe, EA - East Asia, SA - South Asia), which is based on HTAP source/ receptor relationship experiments by reducing anthropogenic emissions by $20 \%$ in each of the four regions. RAIR in a receptor region represents the percentage contribution of the intercontinental transport of foreign sources relative to the sum of foreign and domestic sources. Standard deviations, as indicated by error bars, reflect the variability of the 9 models in the ensemble.

Figures are adapted from HTAP (2010) for surface concentration and Yu et al. (2013) for AOD.

in a region means that $10 \%$ of the AOD reduction in the region comes from the $20 \%$ emission reduction from three other regions combined, with the remaining $90 \%$ of the AOD reduction coming from the $20 \%$ emission reduction in the region itself. Clearly, the aerosol imported via ICT makes significant contribution to climate forcing and air quality, with the magnitude depending on both region and component. RAIR for PM surface concentration ranges from 5 to $20 \%$, whereas RAIR for AOD is larger, having a range of $10-30 \%$. On the other hand, model simulations show a large spread, as reflected by the calculated standard deviations (as represented by error bars) and individual model values of RAIR in Fig. 1. The large model diversity is likely associated with differences in the model treatment of numerous aerosol processes, as extensively documented in a number of inter-comparisons between models and observations (e.g., Schulz et al., 2006; Textor et al., 2006; Textor et al., 2007; Shindell et al., 2008; Koch et al., 2009; Prospero et al., 2010; Yu et al., 2012a). It is important to note that the use of coarseresolution global CTMs is not adequate for representing a suite of small-scale processes that determine how the transported aerosols could change surface PM concentration, clouds, precipitation, and atmospheric circulations.

\subsection{Measurement needs for assessing aerosol intercontinental transport}

There is a pressing need for reliable observations that constrain and improve model assessments of aerosol ICT and its regional impacts. Such observations need to meet some primary requirements. First, measurements should have adequate spatial and temporal coverage to allow for tracking the evolution of aerosol transport over a global or hemispherical scale with a daily or hourly frequency. Second, measurements should provide or can be used to derive highly accurate, quantitative information about aerosol horizontal and vertical distributions, such as mass concentration, mass loading, AOD, and vertical profiles of aerosol extinction. AOD is the quantity most often provided by remote sensing. It is a measure of the integrated aerosol extinction (scattering and absorption) through the atmosphere. AOD can be related to aerosol mass 
loading and surface PM concentration; however this depends on aerosol composition, vertical profile, and meteorological conditions. Third, in the case of remote sensing observations, measurements should distinguish aerosol types, which is essential for identifying aerosol ICT from the measured bulk of particles. The conversion between aerosol optical measurements (e.g., AOD and extinction or backscatter coefficient) and aerosol mass loading or concentration requires aerosol type information because aerosol mass extinction efficiency and its dependence on relative humidity depend on aerosol type. Different types of aerosol also tend to follow different transport paths and exert different impacts on climate and human health.

Large-scale satellite measurements, complemented by regional and local aerosol characterizations from surface stations and field campaigns, can meet these fundamental requirements. Surface stations can offer detailed albeit local measurements of surface concentrations (Prospero, 1999; Propsero et al., 2003), AOD (Holben et al., 1998), and chemical (Malm et al., 2004), microphysical, and radiative (Dubovik et al., 2002) aerosol properties. Intensive field experiments can provide comprehensive snapshots of regional aerosols through coordinated, multiplatform observations (Russell et al., 1999; Huebert et al., 2003; Jacob et al., 2003; Reid et al., 2003; Tanré et al., 2003; Li et al., 2007; Singh et al., 2009; Jacob et al., 2010). For all their advantages, field campaigns and surface stations are inherently limited by relatively short duration and/or small spatial coverage, and alone are not adequate for assessing the temporal and spatial variations of cross-ocean aerosol transport. Even long-term surface networks, such as the Aerosol Robotic Network (AERONET) (Holben et al., 1998), are substantially limited in geographical coverage, particularly over oceans where intercontinental transport occurs. This lack of oceanic coverage is being addressed in part by the Marine Aerosol Network (MAN) (Smirnov et al., 2009); but even so, marine aerosol coverage, both in space and time, remains exceedingly sparse.

Satellite aerosol remote sensing can augment field campaigns and surface networks by expanding temporal and spatial scales because of the inherent advantage of daily or hourly measurements with global or continental coverage over decadal-scale durations. Indeed, ever since meteorological satellites were put into orbit, satellite imagers have been used to detect the aerial extent and motion of large-scale aerosol plumes (e.g., Prospero and Carlson, 1972; Fraser, 1976; Lyons et al., 1978; Fraser et al., 1984; Chung, 1986; Ferrare et al., 1990; Dulac et al., 1992; J. Herman et al., 1997). Some studies also attempted to go beyond simply detection with imagery to estimate columnar atmospheric density and mass transport of desert dust (Fraser, 1976; Mekler et al., 1977; Sirocko and Sarnthein, 1989; Dulac et al., 1992), sulfate pollution (Fraser et al., 1984), and fire smoke (Ferrare et al., 1990) using early satellite measurements. However, such estimates were subject to large uncertainties because of poor data accuracy and the lack of constraints on aerosol microphysical properties and vertical distributions.

In recent decades and particularly during the Earth Observing System (EOS) era starting around 2000, substantial progress has been achieved in satellite remote sensing of aerosols (see summaries by Yu et al., 2009a; Kahn, 2012; and references therein). Satellites are currently providing global land and ocean measurements of AOD with much improved quality. Global measurements of aerosol vertical distributions in cloud-free atmosphere and above low-level cloud are also emerging (Winker et al., 2010; Yu and Zhang, in press). Enhanced remote sensing capabilities for constraining aerosol shape, size, and absorption allow for the characterization of aerosol type (Tanré et al., 2001; Higurashi and Nakajima, 2002; Kaufman et al., 2005a; Kahn et al., 2010; Tanré et al., 2011). Table 1 lists major satellite observables currently available for studying aerosol ICT. Several satellite sensors are also providing value-added observations for aerosol ICT by measuring trace gases such as $\mathrm{SO}_{2}, \mathrm{NO}_{2}$ and $\mathrm{CO}$ (Martin, 2008), that are aerosol precursors or originate from the same sources as particles, and providing means for identifying major aerosol source regions and estimating emissions (e.g., Veefkind et al., 2011; Ichoku et al., 2012). These advances have provided an unprecedented opportunity of going from qualitative tracking to increasingly quantitative characterization and estimates of aerosol crossocean transport.

Qualitative tracking is the first order identification of an aerosol plume that follows its passage from one continent to the other. Satellites provide a means for visualizing these events in a way unavailable by other measurement systems. However, once an event is identified, a series of questions arise. How much aerosol is being transported in this event? What types of particles comprise the plume? At what altitude is the transport? How do the aerosol plume and its particle properties evolve along the transport path? How common is this event? Are there seasonal signatures and inter-annual variations to aerosol ICT? What is the mass flux of the particles that depart at one continent and arrive at another? How much of the aerosol is deposited into the ocean during the intercontinental transport? How can we use the satellite-derived measurements of aerosol ICT events and climatology to constrain models and reduce the model spread seen in Fig. 1? Answering this series of questions requires a progression of increasingly quantitative satellite products, from images of detected plumes to measurements that characterize the aerosol and its transport with verifiable quantities having physical meaning.

In this paper, we review how the increasing satellite measurement capabilities over the EOS-era have been used to (a) improve the understanding of aerosol ICT variations on daily, seasonal, and decadal timescales (Section 2), (b) provide quantitative estimates of aerosol exports and imports (Section 3), and (c) evaluate and constrain model simulations (Section 4). Major conclusions and recommendations are summarized in Section 5.

This review focuses on the satellite perspective of aerosol cross-ocean transport and does not address the fate of those particles once they reach the receptor continent. How these imported particles affect air quality and climate over continents lies beyond the scope of this paper. The main reason for this omission is that currently satellite measurements over land are neither sufficiently sophisticated nor accurate to distinguish imported foreign aerosols from domestic aerosols.

Although it is tempting to try to apply satellite-derived aerosol ICT to air quality applications, there are two issues. First, whereas satellite-observed AOD can be well correlated to surface $\mathrm{PM}_{2.5}$ concentration and hence used for air quality assessment in some cases (e.g., Wang and Christopher, 2003; Engel-Cox et al., 2004; Al-Saadi et al., 2005), the success of its application depends on such factors as aerosol composition, 
Table 1

Summary of major operational and research products from satellite remote sensing that can be applied for characterizing aerosol intercontinental transport.

\begin{tabular}{|c|c|c|c|c|c|c|c|c|c|c|c|}
\hline \multirow[t]{2}{*}{ Sensor/platform } & \multirow[t]{2}{*}{ Swath } & \multirow[t]{2}{*}{$\begin{array}{l}\text { Measurement } \\
\text { period }\end{array}$} & \multirow{2}{*}{$\begin{array}{l}\text { Column } \\
\text { load } \\
\text { AOD }\end{array}$} & \multicolumn{5}{|c|}{$\begin{array}{l}\text { Particle properties (for aerosol } \\
\text { type characterization) }\end{array}$} & \multicolumn{3}{|c|}{$\begin{array}{l}\text { Transport } \\
\text { heights }\end{array}$} \\
\hline & & & & $\mathrm{AE}$ & $\begin{array}{l}\text { FMF/ } \\
\text { size }\end{array}$ & SSA & AAI & NSF & LH & VP & ACA \\
\hline TOMS/Nimbus, ADEOS, EP & $\sim 2700 \mathrm{~km}$ & 1979-2001 & $\swarrow$ & & & & 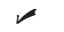 & & & & $\boldsymbol{\swarrow}$ \\
\hline AVHRR series & $\sim 2400 \mathrm{~km}$ & 1981-present & $\nu(0)$ & $(0)$ & & & & & & & \\
\hline A(A)TSR/Envisat & $\sim 500 \mathrm{~km}$ & 1995-present & $\swarrow$ & $\swarrow$ & & & & & & & \\
\hline GOME/ERS-2 & $\sim 2000 \mathrm{~km}$ & $1995-2003$ & 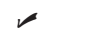 & & & & $\prec$ & & & & \\
\hline GOME-2/METOP & & 2007-present & & & & & & & & & \\
\hline $\begin{array}{l}\text { POLDER/ADEOS } 1 \\
\text { 2/PARASOL }\end{array}$ & $\sim 2400 \mathrm{~km}$ & $\begin{array}{l}\text { 1996, } 2003 \\
\text { 2004-present }\end{array}$ & $r$ & $\swarrow$ & 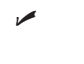 & $\prec$ & & $\prec$ & & & $r$ \\
\hline SeaWiFS/SeaStar & $\sim 2800 \mathrm{~km}$ & $1997-2010$ & 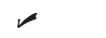 & $\boldsymbol{\swarrow}$ & & & & & & & \\
\hline MISR/Terra & $\sim 360 \mathrm{~km}$ & 2000-present & 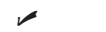 & 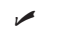 & $\swarrow$ & $\swarrow$ & & 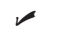 & $\boldsymbol{\nu}$ & & \\
\hline MODIS/Terra & $\sim 2300 \mathrm{~km}$ & 2000-present & $r$ & $\swarrow$ & $\mathscr{\nu}(0)$ & $\mathscr{\nu}(\mathrm{L})$ & & & & & \\
\hline MODIS/Aqua & & 2002-present & & & & & & & & & \\
\hline MERIS/Envisat & $\sim 1150 \mathrm{~km}$ & 2003-present & $\boldsymbol{r}$ & $\boldsymbol{r}$ & & & & & & & \\
\hline SCIAMACHY/Envisat & $\sim 960 \mathrm{~km}$ & 2003-present & $\check{\nu}$ & & & & $\swarrow$ & & & & \\
\hline AIRS/Aqua & $\sim 1600 \mathrm{~km}$ (night) & 2004-present & (dust) & & & & & & (dust) & & \\
\hline OMI/Aura & $\sim 2600 \mathrm{~km}$ & 2004-present & 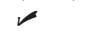 & & & $\boldsymbol{\nu}$ & $\swarrow$ & & & & $\swarrow$ \\
\hline GLAS/ICESat & $\sim 70 \mathrm{~m}$, day and night & 2003-present & 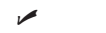 & & & & & & & $\swarrow$ & \\
\hline CALIOP/CALIPSO & $\sim 70 \mathrm{~m}$, day and night & 2006-present & $\mathscr{r}$ & $\boldsymbol{r}$ & & & & $\boldsymbol{\swarrow}$ & & $\boldsymbol{\nu}$ & $\boldsymbol{r}$ \\
\hline IASI/MetOp & $\sim 2050 \mathrm{~km}$ & 2006-present & (dust) & & & & & & (dust) & & \\
\hline VIIRS/NPP Soumi & $\sim 3000 \mathrm{~km}$ & 2012-present & 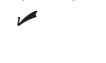 & $(0)$ & $\downarrow(0)$ & & & & & & \\
\hline VISSR/GOES series & $\sim$ Half-hourly, North and Central America & 2003-present & 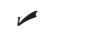 & & & & & & & & \\
\hline SEVIRI/MSG & $\begin{array}{l}\text { Hourly, West Europe, Africa, and the } \\
\text { Atlantic }\end{array}$ & 2004-present & $r$ & & & & & & & & \\
\hline
\end{tabular}

Acronyms: L - Land only; O - Ocean only; AOD - aerosol optical depth; AE - Angstrom exponent; FMF - fine-mode fraction (with respect to AOD); SSA - single-scattering albedo; AAI - absorbing aerosol index; NSF - non-spherical fraction of AOD; LH - layer height; VP - vertical profile; and ACA - above-cloud aerosol.

size, vertical distribution, and meteorological variables (e.g., Gupta et al., 2006; Y. Liu et al., 2005; Liu et al., 2007; Pelletier et al., 2007). Progress and issues in using satellites for air quality applications are reviewed in Hoff and Christopher (2009). Second, an even greater challenge is to infer aerosol ICT influences on surface PM concentration, because of the difficulty in distinguishing between domestic and imported aerosol from satellite once the particles are over land. Another difficulty in linking aerosol ICT to local air quality is that transported particles often arrive elevated above the boundary layer and therefore do not affect surface air quality. Assessing aerosol ICT impacts on air quality should largely rely on speciated PM surface concentration measurements (VanCuren and Cahill, 2002) and model simulations (Chin et al., 2007). Satellite measurements of cross-ocean transport could put the detection of aerosol ICT from surface concentration measurements in context, and provide boundary condition constraints for models and hence reduce the model spread seen in Fig. 1, or the strengths of satellite and model-derived constraints can be combined to assess surface air quality conditions (e.g., Liu et al., 2007; van Donkelaar et al., 2010).

\section{Satellite characterization of aerosol intercontinental transport}

The accumulation of satellite observations over the past decades has significantly advanced the understanding of aerosol intercontinental transport. In this section we review how these observations have been employed to characterize the details of aerosol ICT episodes (Section 2.1), and study variations of aerosol ICT on intra-seasonal, seasonal, and inter-annual time scales (Section 2.2). Major studies are listed in Tables 2a, 2b and 2c.

\subsection{Aerosol ICT episodes}

The daily or hourly observing frequency of satellites allows for tracking the evolution of significant aerosol ICT episodes, such as dust storm outbreaks, severe wildfire smoke, and abrupt volcanic eruption plumes. The extensive spatial coverage of satellite observations also helps establish linkages between in situ measurements in different locations that might be thousands of kilometers apart (Ansmann et al., 2009; Ben-Ami et al., 2010).

\subsubsection{Tracking plumes}

One of the first uses of satellites to characterize aerosol ICT episodes was simply to provide imagery of major aerosol events as those plumes crossed oceans. For example, Husar et al. (2001) used a combination of SeaWiFS, GOES 9, GOES 10 and TOMS UV absorbing aerosol index (AAI) to analyze by hand the approximate location of a dust plume that developed over the Asian Gobi desert and then was transported across the Pacific Ocean over the course of 9 days. The arrival of the dust at the western shore of North America, as determined by satellite analysis, was consistent with elevated concentrations of dust particulate matter measured at in situ stations in California and Oregon. Hsu et al. (2006) used TOMS AAI to determine the 
Table 2a

List of major satellite-based characterizations of episodic aerosol intercontinental transport.

\begin{tabular}{|c|c|c|}
\hline Study & Major characteristics revealed & Satellite aerosol data used \\
\hline \multicolumn{3}{|c|}{ Trans-Atlantic transport of Saharan dust } \\
\hline $\begin{array}{l}\text { Kalashnikova } \\
\text { and Kahn } \\
\text { (2008) }\end{array}$ & $\begin{array}{l}\text { Evolution of horizontal extent, AOD, particle size, particle shape } \\
\text { within four trans-Atlantic dust plumes (June and July 2000) }\end{array}$ & $\begin{array}{l}\text { MISR AOD, Angstrom exponent, non-spherical fraction, stereo height; } \\
\text { MODIS AOD }\end{array}$ \\
\hline Z. Liu (2008) & $\begin{array}{l}\text { Evolution of the vertical extent of dust plumes across North } \\
\text { Atlantic; no discernable changes of particle size and shape } \\
\text { (August 2006) }\end{array}$ & $\begin{array}{l}\text { CALIOP profile of attenuated backscatter, depolarization ratio, and color } \\
\text { ratio }\end{array}$ \\
\hline $\begin{array}{l}\text { Ben-Ami et } \\
\text { al. }(2010)\end{array}$ & $\begin{array}{l}\text { Transport of dust from the Bodele depression to the Amazon } \\
\text { basin (February 2008) }\end{array}$ & $\begin{array}{l}\text { MODIS AOD and FMF, CALIOP attenuated backscatter and volume } \\
\text { depolarization ratio }\end{array}$ \\
\hline $\begin{array}{l}\text { Su and Toon } \\
\text { (2011) }\end{array}$ & $\begin{array}{l}\text { Single and descending Saharan dust layer during the } \\
\text { trans-Atlantic transport }\end{array}$ & CALIOP extinction profile \\
\hline $\begin{array}{l}\text { Nowottnick } \\
\text { et al. } \\
\text { (2011) }\end{array}$ & $\begin{array}{l}\text { Persistent barrier to dust transport along the Central American } \\
\text { coastline (July 2007) }\end{array}$ & MODIS AOD, CALIOP feature mask and attenuated backscatter \\
\hline \multicolumn{3}{|c|}{ Trans-Pacific transport of dust and pollution } \\
\hline $\begin{array}{l}\text { Husar et al. } \\
\quad(2001)\end{array}$ & $\begin{array}{l}\text { Timing and location of Asian dust plume transported across } \\
\text { North Pacific (April 1998) }\end{array}$ & SeaWiFS image, GOES image, TOMS AAI \\
\hline $\begin{array}{l}\text { Chin et al. } \\
\text { (2004) }\end{array}$ & Evaluating model simulations of aerosol distribution (April 2001) & MODIS AOD and fine-mode AOD \\
\hline $\begin{array}{l}\text { Hsu et al. } \\
\qquad(2006)\end{array}$ & $\begin{array}{l}\text { Timing and location of Asian dust plume transported across } \\
\text { North Pacific (April 4-16, 2001) }\end{array}$ & OMI AAI \\
\hline $\begin{array}{l}\text { Huang et al. } \\
\qquad(2008)\end{array}$ & $\begin{array}{l}\text { Multilayered dust structure over China and the western Pacific } \\
\text { Ocean }\end{array}$ & CALIOP extinction/depolarization profiles \\
\hline $\begin{array}{l}\text { Eguchi et al. } \\
\text { (2009) }\end{array}$ & $\begin{array}{l}\text { Two-layered }(4-6 \mathrm{~km}, 8-11 \mathrm{~km}) \text { trans-Pacific Asian dust } \\
\text { transport (May 5-15, 2007) }\end{array}$ & CALIOP extinction profile \\
\hline $\begin{array}{l}\text { Hara et al. } \\
\text { (2009) }\end{array}$ & Trans-pacific Asian dust transport (May 21-31, 2007) & CALIOP extinction profile \\
\hline $\begin{array}{l}\text { Uno et al. } \\
\text { (2009) }\end{array}$ & $\begin{array}{l}\text { Fast transport of Asian dust plume lofted to } 8-10 \mathrm{~km} \text { around } \\
\text { the globe within } 2 \text { weeks (May } 8-22,2007 \text { ) }\end{array}$ & CALIOP extinction and depolarization profile \\
\hline $\begin{array}{l}\text { Yumimoto et } \\
\text { al. (2009) }\end{array}$ & $\begin{array}{l}\text { Three-dimensional structure of Trans-pacific dust transport } \\
\text { (May 21-31, 2007) }\end{array}$ & CALIOP extinction profile, OMI AAI \\
\hline $\begin{array}{l}\text { Yumimoto et } \\
\text { al. (2010) }\end{array}$ & $\begin{array}{l}\text { Summertime Asian dust transported across North Pacific in } \\
13 \text { days (August 2009) }\end{array}$ & CALIOP attenuated backscatter and depolarization \\
\hline $\begin{array}{l}\text { Su and Toon } \\
\text { (2011) }\end{array}$ & Multilayered Asian dust trans-Pacific transport & CALIOP extinction profile \\
\hline $\begin{array}{l}\text { Uno et al. } \\
\text { (2011) }\end{array}$ & $\begin{array}{l}\text { Multiple large Asian dust layers reaching North America (April, } \\
\text { 2010) }\end{array}$ & CALIOP attenuated backscatter, depolarization ratio \\
\hline $\begin{array}{l}\text { Hsu et al. } \\
\text { (2012) }\end{array}$ & $\begin{array}{l}\text { Fast trans-Pacific pollution transport in autumn (reaching } \\
\text { North America in 5-6 days) }\end{array}$ & CALIOP vertical feature mask, OMI SO${ }_{2}$, AIRS CO \\
\hline \multicolumn{3}{|c|}{ Biomass burning and volcanic eruption events } \\
\hline $\begin{array}{l}\text { Damoah et } \\
\text { al. (2004) }\end{array}$ & $\begin{array}{l}\text { Hemispheric transport of forest fire smoke from Russia in } \\
17 \text { days (May 2003) }\end{array}$ & MODIS image and hot spot, SeaWiFS image, TOMS AAI, GOME NO2 \\
\hline $\begin{array}{l}\text { Dirksen et al. } \\
\text { (2009) }\end{array}$ & $\begin{array}{l}\text { Global transport of smoke from the Australian intense forest } \\
\text { fires in } 12 \text { days (December 2006) }\end{array}$ & OMI AAI and plume altitude, CALIOP extinction profile \\
\hline $\begin{array}{l}\text { Winker et al. } \\
\text { (2012) }\end{array}$ & $\begin{array}{l}\text { Characterization of vertical extent and particle shape of the } \\
\text { Eyjafjallajokull volcanic ash (April 2010) }\end{array}$ & CALIOP profile of extinction and depolarization ratio \\
\hline \multicolumn{3}{|c|}{ Transport of mid-latitude aerosols to the polar regions } \\
\hline $\begin{array}{l}\text { Di Pierro et } \\
\text { al. (2011) }\end{array}$ & $\begin{array}{l}\text { Identifying transport of eastern Asian aerosols to the Arctic } \\
\text { (March, April, October, 2007) }\end{array}$ & CALIOP extinction profile \\
\hline $\begin{array}{l}\text { Gasso and } \\
\text { Stein (2007) }\end{array}$ & $\begin{array}{l}\text { Tracking the transport of Patagonian dust to the sub-Antarctic } \\
\text { (April 2006) }\end{array}$ & MODIS AOD, OMI AAI \\
\hline $\begin{array}{l}\text { Li et al. } \\
\text { (2010) }\end{array}$ & $\begin{array}{l}\text { Tracking the transport of Patagonian dust to Antarctic (June } \\
\text { 2006) }\end{array}$ & CALIOP attenuated backscatter \\
\hline
\end{tabular}

approximate location of dust plumes. A series of images from successive days depicts the evolution of Asian dust plumes during the trans-Pacific transport, as illustrated in Fig. 2. Damoah et al. (2004) used a variety of satellite images including MODIS, SeaWiFS, TOMS, and GOME to track the 17-day hemispheric transport of severe forest fires that originated in southeast Russia in May 2003. These satellite images were used to validate the transport routes of the fires simulated by a Lagrangian particle dispersion model. Although these satellite studies offered convincing illustration of aerosol transport across ocean basins, they provided little more than qualitative pictures and did not begin to answer the series of questions posed in Section 1.2.

\subsubsection{Quantifying aerosol loading}

The first step towards a more quantitative characterization of aerosol ICT is to retrieve AOD from the satellite imagery. AOD is an optical measure of the amount of aerosols. It is a 
Table 2b

List of major satellite-based characterizations of seasonal variations of aerosol intercontinental transport.

\begin{tabular}{|c|c|c|}
\hline Study & Major characteristics revealed & Satellite aerosol data used \\
\hline $\begin{array}{l}\text { Kaufman } \\
\text { et al. } \\
\text { (2005c) }\end{array}$ & Dust AOD and mass flux of Saharan dust across the Atlantic Ocean & MODIS AOD and FMF \\
\hline $\begin{array}{l}\text { Heald et } \\
\text { al. } \\
(2006)\end{array}$ & Seasonal variations of trans-pacific AOD for model evaluation & MODIS AOD \\
\hline $\begin{array}{l}\text { Koren et } \\
\text { al. } \\
\text { (2006) }\end{array}$ & Half of the annual dust supply to the Amazon basin coming from the Bodele depression & MODIS AOD and FMF \\
\hline $\begin{array}{l}\text { Generoso } \\
\text { et al. } \\
\text { (2008) }\end{array}$ & Vertical distribution of trans-Atlantic dust transport and deposition & CALIOP attenuated backscatter \\
\hline $\begin{array}{l}\text { D. Liu } \\
\text { (2008) }\end{array}$ & Altitude-resolved frequency of dust transport in Northern Hemisphere & $\begin{array}{l}\text { CALIOP profiles of attenuated backscatter and volume } \\
\text { depolarization ratio }\end{array}$ \\
\hline $\begin{array}{l}\text { Tian et al. } \\
\text { (2008) }\end{array}$ & Relationships between aerosol variability and MJO & TOMS AI, AVHRR AOD, MODIS AOD \\
\hline $\begin{array}{l}\text { Yu et al. } \\
\text { (2008) }\end{array}$ & AOD and mass flux of pollution/smoke aerosols during the trans-Pacific transport & MODIS AOD and FMF, GLAS extinction profile \\
\hline $\begin{array}{l}\text { Ben-Ami } \\
\text { et al. } \\
\text { (2009) }\end{array}$ & Bi-modal distributions of the average dust plume height in both winter and summer & CALIOP attenuated backscatter \\
\hline $\begin{array}{l}\text { Huang et } \\
\text { al. } \\
\text { (2010) }\end{array}$ & $\begin{array}{l}\text { Comprehensive compilation of observational statistics of trans-Atlantic dust transport } \\
\text { from extreme African dust outbreaks }\end{array}$ & MODIS AOD and FMF, CALIOP vertical feature mask \\
\hline $\begin{array}{l}\text { Peyridieu } \\
\text { et al. } \\
\text { (2010) }\end{array}$ & AOD and altitude of trans-Atlantic dust transport & $\begin{array}{l}\text { AIRS dust AOD and altitude, MODIS AOD, PARASOL } \\
\text { AOD, } \\
\text { CALIOP layer altitude }\end{array}$ \\
\hline $\begin{array}{l}\text { Tian et al. } \\
\text { (2011) }\end{array}$ & Correlation of AOD with MJO in the tropical Atlantic Ocean & MODIS AOD \\
\hline $\begin{array}{l}\text { Ben-Ami } \\
\text { et al. } \\
\text { (2012) }\end{array}$ & $\begin{array}{l}\text { Annual triplet of trans-Atlantic dust transport: southern-route, northern-route, and } \\
\text { transitional period }\end{array}$ & MODIS AOD and FMF \\
\hline $\begin{array}{l}\text { Ford and } \\
\text { Heald } \\
(2012)\end{array}$ & Aerosol removal may be too efficient in the model & MODIS AOD, CALIOP AOD and extinction profile \\
\hline $\begin{array}{l}\text { Ridley et } \\
\text { al. } \\
\text { (2012) }\end{array}$ & Assessing model representation of North African dust export and deposition & MODIS AOD, MISR AOD, CALIOP extinction profile \\
\hline $\begin{array}{l}\text { Yu et al. } \\
\text { (2012a) }\end{array}$ & $\begin{array}{l}\text { Mass fluxes of transpacific and transatlantic aerosol transport comparable to the } \\
\text { domestic emissions in North America }\end{array}$ & $\begin{array}{l}\text { MODIS AOD and FMF, CALIOP profile of extinction and } \\
\text { depolarization ratio }\end{array}$ \\
\hline
\end{tabular}

quantitative parameter because it has physical meaning (the vertical integral of the aerosol extinction coefficient) and can be validated against well-characterized ground-truth measurements (Holben et al., 1998; Ichoku et al., 2002). In contrast, the AAI used to identify the plume in Fig. 2 is a qualitative index lacking unambiguous physical meaning and impossible to validate quantitatively. AOD has been acquired from sensors that were designed for other purposes in the 1980s and 1990s, e.g., the Advanced Very High Resolution Radiometer (AVHRR), the Total Ozone Mapping Spectrometer (TOMS), and the Geostationary Operational Environmental Satellite (GOES). However AOD accuracy from these early sensors is generally

Table 2c

List of major satellite-based characterizations of interannual variations of aerosol intercontinental transport.

\begin{tabular}{|c|c|c|}
\hline Study & Major characteristics revealed & Satellite aerosol data used \\
\hline $\begin{array}{l}\text { Moulin et al. } \\
\text { (1997) }\end{array}$ & $\begin{array}{l}\text { Correlation of dust export to North Atlantic Ocean } \\
\text { and the Mediterranean Sea with NAO }\end{array}$ & Meteosat dust AOD (1984-1994) \\
\hline $\begin{array}{l}\text { Chiapello et al. } \\
\text { (2005) }\end{array}$ & $\begin{array}{l}\text { Correlation of trans-Atlantic dust transport with the } \\
\text { Sahel drought }\end{array}$ & TOMS AAI, Meteosat dust AOD (1979-2000) \\
\hline $\begin{array}{l}\text { Doherty et al. } \\
\text { (2008) }\end{array}$ & $\begin{array}{l}\text { Northern and Southern mode of African dust } \\
\text { transport to the Caribbean controlled by distinct } \\
\text { source regions and meteorology }\end{array}$ & TOMS AAI (1979-2000) \\
\hline Yu et al. (2008) & $\begin{array}{l}\text { Inter-annual variations of trans-Pacific transport } \\
\text { flux of pollution/smoke aerosols controlled by that of Siberia fires }\end{array}$ & MODIS AOD and FMF (2002-2005), GLAS aerosol profile \\
\hline $\begin{array}{l}\text { Evan and } \\
\text { Mukhopadhyay } \\
\text { (2010) }\end{array}$ & $\begin{array}{l}\text { Multi-decadal (1955-2008) variations of trans-Atlantic } \\
\text { dust transport }\end{array}$ & $\begin{array}{l}\text { MODIS AOD and FMF, AVHRR AOD (and dust proxy of crustal } \\
\text { helium- } 4 \text { flux from a coral) }\end{array}$ \\
\hline $\begin{array}{l}\text { Peyridieu et al. } \\
\text { (2010) }\end{array}$ & $\begin{array}{l}\text { 2003-2009 AOD and altitude of trans-Atlantic dust } \\
\text { transport }\end{array}$ & AIRS dust AOD and altitude, MODIS AOD \\
\hline
\end{tabular}




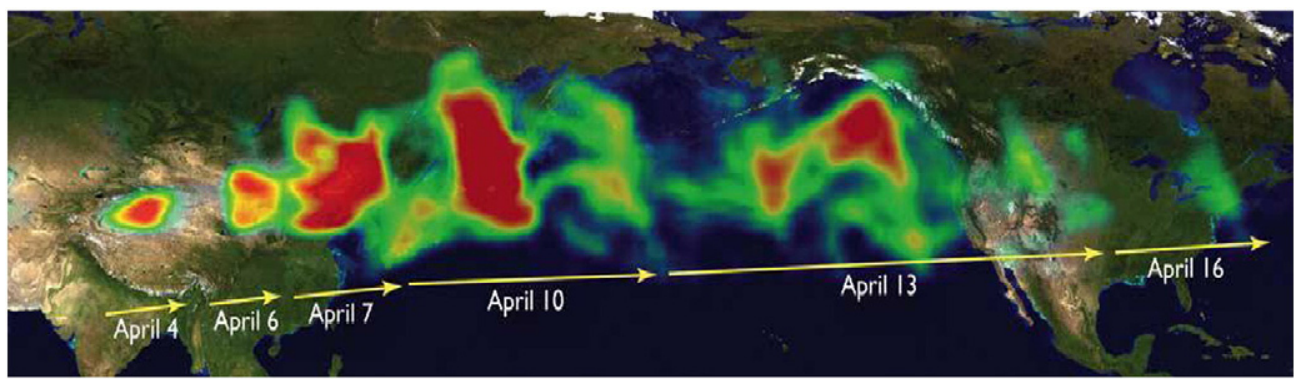

Fig. 2. Trans-Pacific transport route of Asian dust in April 2001 as illustrated by a time series of TOMS UVAI composite. Figure taken from Hsu et al. (2006).

low. Major sources of AOD uncertainty are associated with instrument calibration, band characteristics, spatial resolution, cloud contamination, surface reflectance, and assumed aerosol optical models (Zhao et al., 2008). Because of these uncertainties, the AOD from these satellites did not provide greater quantitative insight into aerosol ICT than did the plume transport studies using AAI, as described earlier.

In contrast, the EOS-era (2000-present) instruments offer a higher degree of quantitative characterization of episodic transport, because of improved AOD accuracy. During this

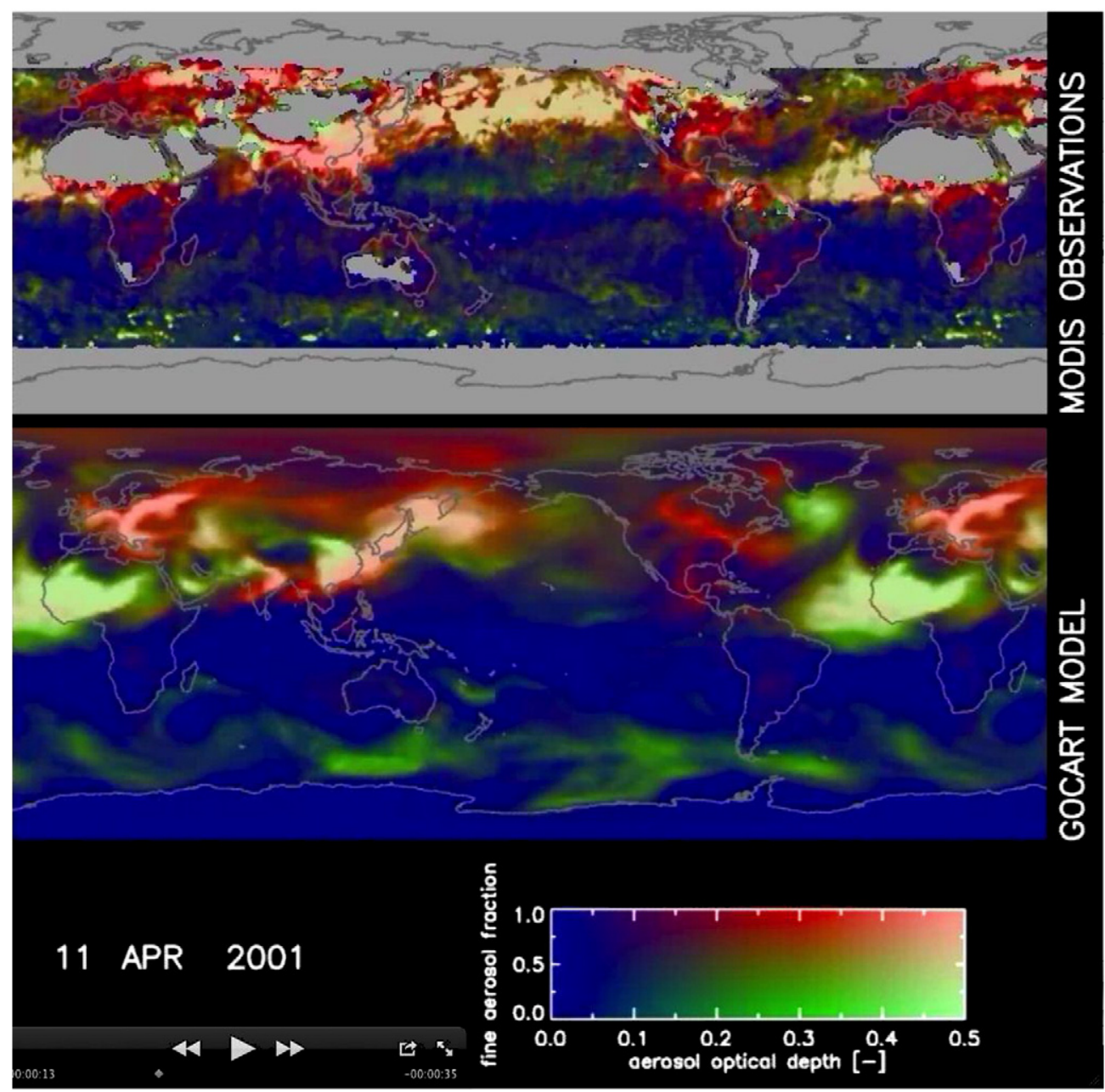

Fig. 3. Spatial variations of aerosol type on April 11, 2001 as revealed by a composite of aerosol optical depth (at $550 \mathrm{~nm}$ ) and fine-mode fraction observed by MODIS/Terra (top panel) and simulated by GOCART model (bottom panel) for April 11, 2001. Industrial pollution and biomass burning aerosols are predominated by small particles (shown as red), while mineral dust consists of a large fraction of large particles (shown as green). Bright red and bright green indicate heavy pollution and dust plumes, respectively. Image credit: Reto Stockli and Yoram Kaufman. 
period, on-orbit calibration has been implemented widely. Improvements in pixel resolution and spectral range make the cloud screening more robust than before (Martins et al., 2002), though cloud contamination remains a major issue for aerosol remote sensing (Kaufman et al., 2005a; Zhang et al., 2005; Kahn et al., 2009). Several techniques based on enhanced sensor capabilities such as new channels (Kaufman et al., 1997; Hsu et al., 2004), multi-angle views (Diner et al., 1998; Martonchik et al., 1998, 2002, 2009), and polarization (M. Herman et al., 1997; Deuzé et al., 2001), have been developed that improve the overall accuracy and coverage of AOD retrievals. Examples of sensors having these advanced capabilities include the Polarization and Directionality of the Earth's Reflectance (POLDER), MODerate resolution Imaging Spectroradiometer (MODIS), Multi-angle Imaging SpectroRadiometer (MISR), Ozone Measurement Instrument (OMI), and Cloud-Aerosol Lidar with Orthogonal Polarization (CALIOP). Major characteristics of these advanced sensors are described in Supplementary Online Material (SOM). These sensors provide global measurements of AOD over both land and ocean with accuracy on order of $20 \%$ or \pm 0.05 (e.g., Chu et al., 2002; Remer et al., 2002, 2005; Levy et al., 2010; Hsu et al., 2004; Lyapustin et al., 2011; Kahn et al., 2005, 2010; Abdou et al., 2005; Fan et al., 2008; Ahn et al., 2008).

Making use of the Terra-MODIS sensor's wide swath, validated AOD product and information that partitions AOD into fine and coarse modes, daily snap shots of the Earth's aerosol system became available (Remer et al., 2005; Chin et al., 2004). Fig. 3 shows the intercontinental transport of dust and pollution/smoke aerosol on April 11, 2001 as revealed by the composite of AOD and fine-mode fraction from MODIS observations and the Goddard Chemistry Aerosol Radiative Transport (GOCART) simulations. Industrial pollution and biomass burning aerosols are predominately small particles and shown as red, whereas mineral dust and sea salt are primarily large particles and shown as green. Applying temporal averaging to these daily global images and accumulating a year's set of images, animations were constructed that clearly showed intercontinental transport of fine and coarse particles [see Supplementary Online Material]. Saharan dust crossed the Atlantic not as a continuous stream, but in waves. Similarly, specific episodes of fine mode aerosol left the eastern U.S. for Europe and multi-modal aerosol crossed the Pacific as welldefined events.

Remote sensing of AOD from the daytime polar-orbiting sensors mentioned above is complemented by measurements from infrared sensors and geosynchronous satellites. These types of observations allow for characterization of aerosol ICT at night or at much finer temporal resolutions during the day (Pierangelo et al., 2004; DeSouza-Machado et al., 2006; Peyridieu et al., 2010; DeSouza-Machado et al., 2010; Knapp et al., 2002; Prados et al., 2007; Thieuleux et al., 2005; Laszlo et al., 2008). However, geostationary measurements have been underused for studying aerosol ICT.

\subsubsection{Quantifying aerosol particle properties}

The second step towards a more quantitative characterization of aerosol ICT and answering the series of questions posed in Section 1.2 requires better characterization of particle properties. This step is necessary to provide the information that allows calculation of mass loading from optical loading
(AOD), to differentiate different types of aerosol involved in the transport and to characterize the change in the particles as they age and are transported over great distances.

The EOS-era instruments made significant improvement over the heritage sensors of the 1980s and 1990s in the ability to characterize particle properties. The MODIS multiwavelength measurements over wide spectral range make it feasible to retrieve quantitative aerosol size parameters (e.g., effective radius, fine-mode fraction or FMF of AOD) over dark water (Remer et al., 2005; Levy et al., 2010). The MISR multi-angle data sample a wide range of scattering angles, yielding constraints on particle size, absorption (Kahn et al., 1998, 2001, 2005, 2010; Chen et al., 2008), and shape (Kalashnikova and Kahn, 2006). POLDER's unique capability of measuring spectral and angular polarization can yield additional insights into the shape of coarse-mode particles over ocean under optimal geometrical conditions (Herman et al., 2005). Ongoing development of POLDER enhanced algorithms is expected to produce measurements of aerosol absorption and altitude (Tanré et al., 2011; Dubovik et al., 2011). OMI AAI can be used to distinguish altitude-elevated UV-absorbing aerosols such as dust, smoke, and volcanic ash from scattering aerosol like sulfate (Hsu et al., 1996; J. Herman et al., 1997). Finally the measurements of aerosol microphysical and optical properties can be used in conjunction with measurements of trace gases $\left(\mathrm{SO}_{2}, \mathrm{NO}_{2}\right.$, and $\left.\mathrm{CO}\right)$ (Heald et al., 2003; Edwards et al., 2004; Bian et al., 2010; Veefkind et al., 2011) and identified source locations (Prospero et al., 2002; Ichoku et al., 2012) to improve aerosol characterization.

Because of the above advances, now satellites had opportunities for not only tracking the spatial extent of the influence of episodes, but also of characterizing particle property evolution during the cross-ocean transport. Kalashnikova and Kahn (2008) analyze the trans-Atlantic transport of four dust plumes during a peak dust season using MISR and MODIS aerosol products. They report the evolution of horizontal extent, AOD, particle size, and particle shape within the plumes. As dust is transported across the Atlantic, AOD and its non-spherical fraction systematically decrease, whereas Angstrom exponent increases. For the thick part of the plume (AOD > 0.5), Angstrom exponent and spherical fraction of AOD increase by about $30 \%$ as the plumes traveled from the coast of North Africa to the Caribbean Sea. The study also demonstrates how a combination of complementary information from the two sensors can be used to gain better characterization of cross-ocean dust transport. MODIS provides more extensive coverage, whereas MISR's multi-angle retrievals include dust properties and fill in areas where glint precludes MODIS retrievals.

\subsubsection{Characterizing aerosol vertical distributions}

The most prevalent use of EOS-era satellite sensors to characterize aerosol ICT events or episodes makes use of the CALIPSO lidar that offers vertical profiles for identifying transport height, color ratio that provides qualitative particle size and depolarization that distinguishes non-spherical particles such as dust (Winker et al., 2009, 2010). With successive CALIPSO lidar profiles, Z. Liu et al. (2008) track the crossAtlantic transport of a dust plume that originated in the Sahara desert on August 17, 2006 for a period of 10 days. They found 


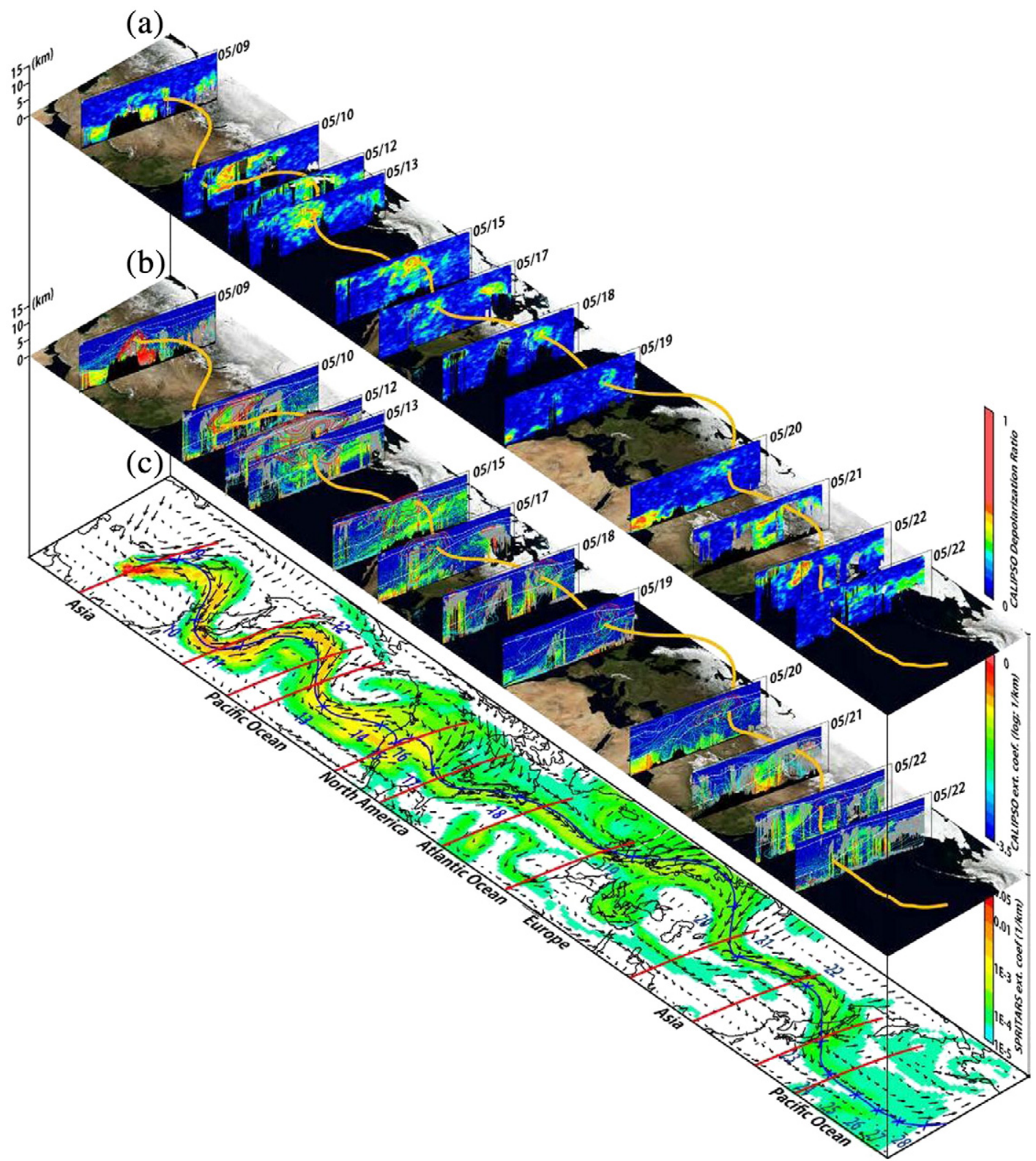

Fig. 4. A three-dimensional view of the hemispherical transport of Asian dust during May 9-22, 2007 as provided by CALIOP measurements of vertical distributions of depolarization ratio (a, dust is distinguished from other types of aerosols by exhibiting high depolarization ratio) and extinction coefficient (b), and a global model simulation of extinction coefficient in the dust layer (c). The vertical and horizontal transport paths are further illustrated by HYSPLIT trajectories.

Figure taken from Uno et al. (2009), with permission from Nature Geoscience.

that it took about a week for the dust plume to reach the Caribbean from North Africa, as the optical depth decreased significantly and the plume top descended by about $3.3 \mathrm{~km}$. However, unlike the plumes studied with MISR observations (Kalashnikova and Kahn, 2008) discussed in Section 2.1.3, the size and shape of the dust particles didn't show discernable changes during transport. After entering the Caribbean region, the transport slowed, and dust was mixed with other types of aerosol over the Gulf of Mexico, as indicated by changes in color ratio and lidar ratio.
Trans-Pacific transport of dust has also been characterized by using successive CALIOP curtains in conjunction with other satellite sensors or models, including Huang et al. (2008), Uno et al. (2008), Eguchi et al. (2009), Uno et al. (2009), Su and Toon (2011), Yumimoto et al. (2009), and Uno et al. (2011). Fig. 4 shows a three-dimensional view of the hemispherical journey of strong dust event originated, from the Taklimakan desert during May 09-22, 2007 as provided by CALIOP for vertical distributions of depolarization ratio (a) and extinction coefficient (b), and a global aerosol transport model for 
horizontal distribution of dust extinction coefficient (c) (Uno et al., 2009). The HYSPLIT trajectory also illustrates the dust transport path in both horizontal and vertical directions. For this extreme dust storm, dust was lofted to 8-10 km and was transported to the mid-Pacific in 4 days, and in about 13 days, it traveled more than one full circuit around the Northern Hemisphere. On returning to the northwestern Pacific Ocean, the dust then descended within a large-scale high-pressure system.

Strong smoke and volcanic eruption events have been characterized by CALIOP and other satellite measurements. Dirksen et al. (2009) tracked a smoke aerosol plume released by intense forest fires in Australia that circumnavigated the world in 12 days. The study also takes advantage of the $\mathrm{O}_{2}-\mathrm{O}_{2}$ absorption feature at $477 \mathrm{~nm}$ from passive sensor OMI that contains useful information on the altitude of cloud or aerosol layers (Acarreta et al., 2004), complementing the CALIOP measurements. Winker et al. (2012) used CALIOP data to characterize the transport of ash from the Eyjafjallajokull volcano in April 2010, including height and vertical extent of the layers and particle shape during both day and night. They observed that particle layers have strong lidar depolarization similar to mineral dust, suggesting the predominance of ash over sulfate in the plumes (Winker et al., 2012).

CALIOP measurements over both day and night are useful to some extent for characterizing transport events of eastern Asian aerosols to the Arctic (Di Pierro et al., 2011) and of Patagonian dust to Antarctica (Li et al., 2010). However, the usually low aerosol loading in polar regions generally requires a space-borne lidar with a detection limit lower than CALIOP. In comparison to active sensors, passive sensors have much greater difficulties in detecting the poleward transport of aerosols at high latitudes, because of low solar signal and hence more uncertain aerosol retrieval, and the presence of abundant clouds in the roaring forties (Gasso and Stein, 2007; Li et al., 2010).

\subsection{Aerosol ICT climatology}

The above section (Section 2.1) describes how increasing satellite capability enhances the ability to characterize aerosol ICT events horizontally and vertically, enabling us to characterize the type of particles transported, follow the plumes and their evolution as they transverse ocean basins and even circumnavigate the globe. The following questions remain unanswered: How common are these events? Are there seasonal signatures and inter-annual variations to aerosol ICT? What controls these variations? These questions can be readily answered with the routine, long-term duration of satellite measurements. Satellite aerosol products are easily accumulated and averaged, and when these statistics are derived over oceans, we assume that the elevated aerosol loading is due to transport from continents. However, without additional information, either from tracking specific events, analysis of ancillary meteorological data, or model trajectories, the statistics of oceanic aerosol retrievals cannot be directly attributed to transport from a specific location. It helps if satellites provide additional information about the particle properties to identify certain mean aerosol loading to be associated with an aerosol type originating from continents (e.g., dust or combustion particles).

\subsubsection{Intra-seasonal and seasonal variations}

An analysis of aerosol observations from TOMS, AVHRR, and MODIS looked for intra-seasonal variations in AOD over the tropical Pacific and Indian oceans, with inconclusive results due to difficulties in interpreting the satellite products in these regions, namely possible cloud contamination or other ambiguities contributing to the observed patterns (Tian et al., 2008). However, a follow-up study applied the same technique over the tropical Atlantic, and showed that about $25 \%$ of the total variance of MODIS AOD can be accounted for by the intra-seasonal variability related to the Madden-Julian Oscillation (MJO) (Tian et al., 2011).

Seasonal variations of trans-Atlantic dust transport have been extensively studied using measurements from passive sensors, often supplemented with ancillary data (e.g., Kaufman et al., 2005c; Schepanski et al., 2009; Huang et al., 2010; Ben-Ami et al., 2012; Ridley et al., 2012) and active sensors (Generoso et al., 2008; Ben-Ami et al., 2009; Huang et al., 2010; Yu et al., 2010; Ridley et al., 2012). The hurdle that these studies had to overcome was identifying the dust component from the other aerosol types, because dust and smoke are often mixed in winter and spring in the east Atlantic (Haywood et al., 2008). This separation can be done by using depolarization from CALIOP (D. Liu et al., 2008), by retrieving detailed aerosol particle properties from multi-angle and/or polarization measurements (Kahn et al., 2010; Herman et al., 2005) or by combining size parameters derived from satellite sensor with assumptions gleaned from climatological analysis (Kaufman et al., 2005b, 2005c; Yu et al., 2009b).

The lidar depolarization method (Winker and Osborn, 1992) makes use of the fact that spherical particles such as pollution, smoke and sea salt do not create a depolarization signal, but irregularly shaped, large dust particles do (McNeil and Carswell, 1975; Barnaba and Gobbi, 2001; Murayama et al., 2001; Liu et al., 2002; Mattis et al., 2002; Z. Liu et al., 2008). Dust can also be separated from combustion particles such as smoke and pollution when a sensor characterizes the multi-dimensional reflectance field, including multiple wavelengths across a broad spectral range, multiple angles over a wide range of scattering angles and polarization states (Dubovik and King, 2000; Mishchenko et al., 2005). MISR provides multi-wavelength, multi-angle measurements and provides retrievals of particle properties of which nonsphericity is the most important for identifying dust (Kalashnikova and Kahn, 2006). PARASOLPOLDER is also multi-wavelength, multi-angle instrument and adds polarization, making it capable of directly retrieving sufficient information on particle properties to discern dust (Herman et al., 2005; Tanré et al., 2011).

On the other hand, MODIS with its single angle view of each scene and no polarization does not measure sufficient information to directly retrieve the particle properties that unambiguously identify dust. Following Kaufman et al. (2005b, 2005c), the MODIS studies assume:

$$
\begin{aligned}
& \tau=\tau_{\mathrm{du}}+\tau_{\mathrm{co}}+\tau_{\mathrm{ma}} \\
& \tau_{\text {fine }}=\mathrm{f} \tau=\mathrm{f}_{\mathrm{du}} \tau_{\mathrm{du}}+\mathrm{f}_{\mathrm{co}} \tau_{\mathrm{co}}+\mathrm{f}_{\mathrm{ma}} \tau_{\mathrm{ma}}
\end{aligned}
$$

where Eq. (1) assumes that the total AOD $(\tau)$ retrieved by MODIS is composed of a dust component $\left(\tau_{\mathrm{du}}\right)$, a combustion aerosol component $\left(\tau_{\mathrm{co}}\right)$ and a marine aerosol component 


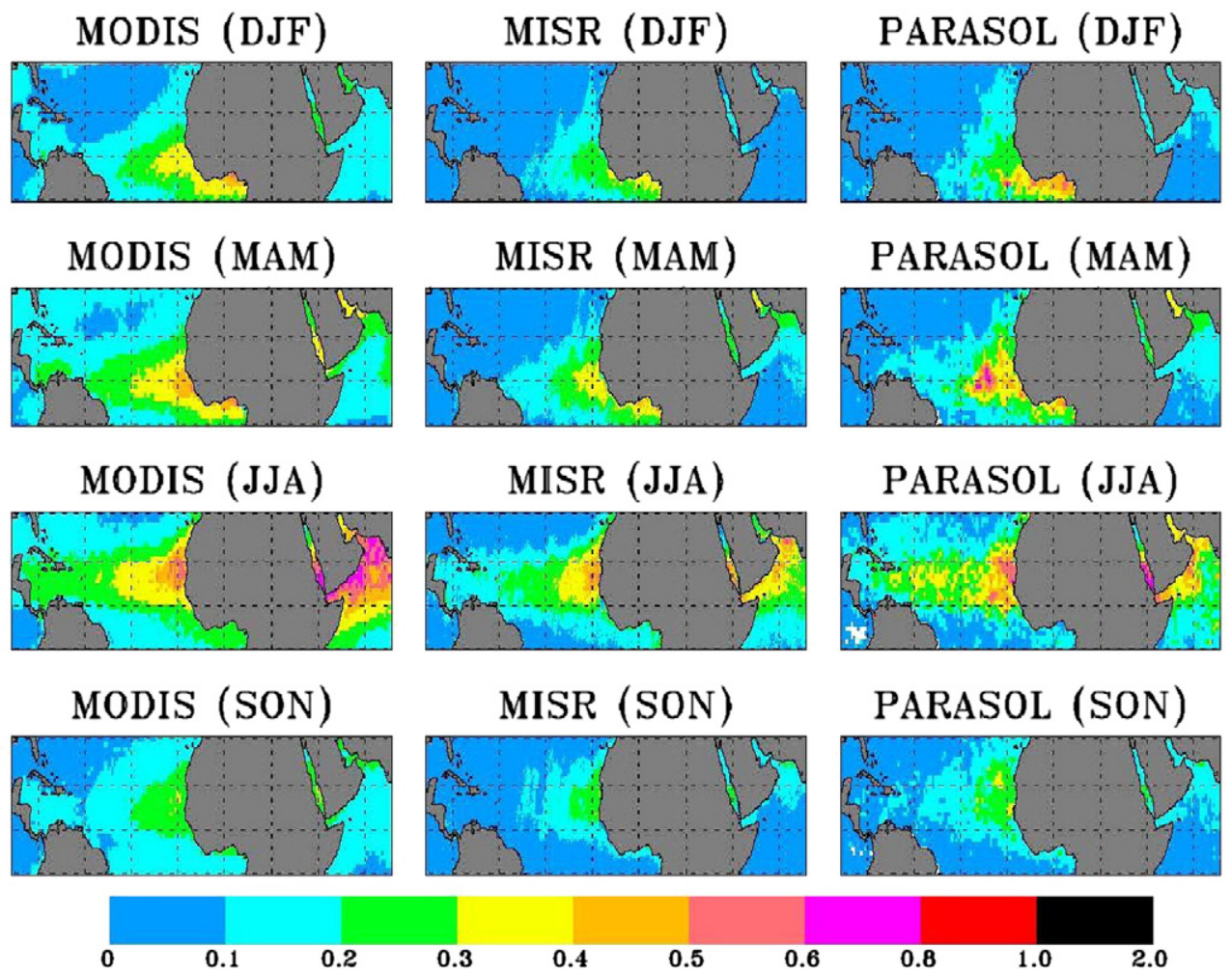

Fig. 5. Seasonal variations of trans-Atlantic transport of dust AOD observed by MODIS, MISR, and PARASOL.

$\left(\tau_{\text {ma }}\right)$. Eq. (2) assumes that the fine mode AOD $\left(\tau_{\text {fine }}=f \tau\right.$ the fraction of the total AOD contributed by fine particles) is composed of a sum of the fine mode AODs of each component in Eq. (1). Note that the fine mode fraction (f) is the ratio of fine mode AOD and the total AOD,

$\mathrm{f}=\frac{\tau_{\text {fine }}}{\tau}$.

MODIS derives two pieces of information, the total AOD $(\tau)$ and the total fine-mode fraction (f). This means that all but two of the parameters on the right hand side of Eqs. (1) and (2) must be assumed. The assumed quantities are $f_{d u}, f_{c o}$, $f_{\text {ma }}$ and $\tau_{\text {ma. }}$. The values for these assumptions are taken from MODIS retrievals of $f$ and $\tau$ in regions that are expected to be pure dust, pure combustion aerosol etc., and are assumed roughly the same for other regions. $f_{m a}$ was found to vary spatially and seasonally (Yu et al., 2009b) and is therefore a function of location and time. Given these assumptions and the MODIS direct retrievals of $\mathrm{f}$ and $\tau, \tau_{\mathrm{du}}$ and $\tau_{\text {co }}$ can be inferred. Note that at no point in this method is it assumed that dust is pure coarse mode $\left(f_{d u} \neq 0\right)$ or combustion aerosol is pure fine mode $\left(\mathrm{f}_{\mathrm{co}} \neq 1\right)$, but the actual values are fixed for a given season and region, and are obtained as described above.

Because each sensor, to differing degrees of quantification accuracy, can discern dust from the total aerosol signal observed, all have been used to characterize seasonal and inter-annual variations of dust transport. As an illustration, Fig. 5 shows a multi-sensor (including MODIS, MISR, and PARASOL) view of seasonal variations of trans-Atlantic dust transport. In general, these satellite observations show consistent seasonal variations of trans-Atlantic dust transport, i.e., stronger in summer and spring than in winter and fall. On the other hand, notable differences exist in the magnitude of dust AOD. For example, although PARASOL only senses the coarse-mode non-spherical particles in this plot (Tanré et al., 2011), its AOD value is comparable to the sum of fine-mode and coarse-mode dust AOD as seen by MODIS and MISR. Note that fine-mode dust makes significant (e.g., 37\%) contributions to the total dust AOD for MODIS observations (Yu et al., 2009b). In the Gulf of Guinea, MODIS and PARASOL show much higher dust AOD than MISR does in winter. The complexity of dust and smoke mixture in the region creates a challenging environment for distinguishing dust from smoke using satellites (Kahn et al., 2009; Yu et al., 2009b). In such a situation, MISR would be the sensor of choice, though the known issues with that product (e.g., Kahn et al., 2010) should also be taken into account. As PARASOL algorithms are further developed to make better use of the full complement of its measurements and information content (Dubovik et al., 2011), we anticipate that its retrievals will draw closer to MISR's.

The seasonal variations of columnar AOD observed by passive sensors are complemented by lidar measurements of aerosol vertical distributions. Recently available CALIPSO data confirm the previously observed seasonal differences of trans-Atlantic dust transport heights, namely higher in summer than in winter (Generoso et al., 2008; Ben-Ami et al., 2009; Huang et al., 2010; Yu et al., 2010; Ridley et al., 2012). These same analyses also show that a significant part of the dust is transported near and within the marine boundary layer, suggesting significant dust deposition to the ocean and 
hence important implications for ocean biogeochemistry. Vertical structures of dust and pollution transport on global and hemispherical scales have also been analyzed using CALIOP measurements (D. Liu et al., 2008; Yu et al., 2010; Ford and Heald, 2012; Koffi et al., 2012; Yu et al., 2012a).

\subsubsection{Inter-annual variations}

Decadal-scale satellite measurements of aerosols, many relying on pre-EOS-era satellites to obtain longer time series, have been used to study inter-annual variations of aerosol ICT and their controlling factors (Table 2c). Such studies are not necessarily trend studies, which are particularly sensitive to calibration drift in the sensors (Levy et al., 2010; Zhang and Reid, 2010). If focused on a particular region with high aerosol loading and strong inter-annual amplitudes, the aerosol variability can be distinguished above sensor artifacts (Zhang and Reid, 2010). Several studies have investigated interannual variation in the export of Saharan dust using satellite data. Moulin et al. (1997) used daily Meteosat observations of dust from 1984-1994 and found that inter-annual variability of dust export to the North Atlantic Ocean and the Mediterranean Sea are well correlated with the North Atlantic Oscillation (NAO). By using multi-decadal TOMS AAI and ground-based dust measurements, Chiapello et al. (2005) found that the Sahel drought has a large-scale impact on dust emissions and trans-Atlantic transport in both the subsequent winter and summer, and that the NAO controls the northern branch of wintertime transport. Doherty et al. (2008), also using the multi-decadal TOMS AAI data, found that African dust is transported into the Caribbean via two routes associated with distinct source regions and controlled by different meteorology. In the northern mode, dust mobilized from the Sahara is transported westward, controlled primarily by the longitudinal displacement of the Azores High. In contrast, in the southern mode, dust originating from the Sahel region is transported to the Caribbean via the Gulf of Guinea, controlled primarily by longitudinal displacement and surface pressure fluctuations of the Hawaiian High. Note that the pre-EOS era sensors of Meteosat and TOMS sensors alone cannot distinguish dust from smoke in the above studies, whereas it is necessary to assess how inter-annual variations of smoke aerosol may have contributed to the analyzed inter-annual variations of dust.

Climatology of aerosol parameters has been constructed from the EOS-era satellites (Remer et al., 2008; Dey and Di Girolamo, 2010; Tanré et al., 2011). These do show inter-annual variability of the aerosol system, including inter-annual variability of aerosol distribution across ocean basins. Nevertheless the question of the variability of ICT specifically is not adequately addressed in these relatively short time series. Undoubtedly, an aerosol data record longer than the 10 years of EOS-era satellite observations is essential for a better understanding of the climate impacts of aerosol ICT and controlling processes. There have been a few attempts at extending the relatively short EOS era datasets by using pre-EOS sensors as proxies. Evan and Mukhopadhyay (2010) attempted to extend the MODIS-estimated dust AOD (Kaufman et al., 2005c) over the northern tropical Atlantic back to 1955 by simply scaling AVHRR total AOD (1982-2008) with the MODIS dust AOD fraction (2002-2008) and using a proxy record of atmospheric dust (namely crustal helium-4 flux from a coral $5 \mathrm{~m}$ under the water near Sal Island). However, such an extension would be more credible if built upon understanding and reconciliation of AOD differences between the EOS-era and historic sensors (Jeong et al., 2005). For this a closer examination of relevant issues associated with individual sensors is urgently needed, including instrument calibration, algorithm assumptions, cloud screening, data sampling and aggregation, among others (Zhao et al., 2008). Substantial efforts have been dedicated toward addressing these issues across the EOS-era sensors (Zhang et al., 2005; Kahn et al., 2009; Levy et al., 2009; Zhang and Reid, 2010). However, the cross examination of EOS-era sensors and historical sensors remains basically unexplored. A reliable long-term data record will only be accessible after these issues have been adequately addressed.

\section{Satellite estimates of aerosol export and import mass flux}

The vast majority of studies that address aerosol ICT using satellite data alone have fallen under the subject of the previous two sections: characterizing specific events and episodes, or providing insight into seasonal and inter-annual variation. These studies progressed from qualitatively following an aerosol plume across ocean basins, to gradually adding quantitative information about the evolution of particle properties and height. The aerosol climatology across ocean basins could be interpreted as aerosol transport, with the relative changes from season-to-season or year-to-year identified, even if the quantitative total transport was not addressed. Can satellites take the next step to translate their measurements of optical loading (AOD) and particle properties to mass units? What is the mass flux of the particles that depart at one continent and arrive at another continent? In recent years, a few studies have taken advantage of the advances in aerosol remote sensing to begin to answer these questions.

\subsection{Recent progress}

Although similar efforts have attempted using early satellite measurements more than two decades ago to estimate columnar atmospheric density and transport of desert dust, pollution, and fire smoke (Fraser, 1976; Mekler et al., 1977; Fraser et al., 1984; Sirocko and Sarnthein, 1989; Ferrare et al., 1990; Dulac et al., 1992), such estimates were subject to large uncertainties because of poor data accuracy and the lack of constraints on aerosol microphysical properties and vertical distributions. Most recently, EOS-era measurements have been used to estimate the trans-Atlantic transport of dust mass (Kaufman et al., 2005c; Koren et al., 2006), trans-Pacific transport of combustion aerosol mass (including industrial pollution and biomass burning smoke) (Yu et al., 2008) and dust mass (Yu et al., 2012a), and cross-Mediterranean Sea transport of European pollution mass (Rudich et al., 2008).

The estimates of material fluxes in continental outflows and inflows generally follow a three-step approach. First, satellite measurements of AOD and aerosol microphysical properties (e.g., size, shape) are used to distinguish mineral dust from combustion-related aerosol (Kaufman et al., 2005a; Yu et al., 2009b; and Section 2.2). Second, AOD for dust or combustion aerosol is converted to aerosol (dry) mass concentration profile using in-situ measurements of aerosol hygroscopic property (depending on relative humidity and aerosol type) and lidar 
measurements of aerosol vertical distributions (Yu et al., 2008, 2012a). Third, the aerosol mass concentration in combination with zonal wind speed is used to estimate the zonal export and import of aerosol.

There has been a progression in these recent studies as new information became available. The first study of this type (Kaufman et al., 2005c) determined aerosol height from a few field experiments, confirmed by applying a technique that used paired Terra and Aqua MODIS images to determine transport displacement over a few hours and correlated this with wind speed at various heights using reanalysis data (Koren and Kaufman, 2004). They also assumed single value for $\mathrm{f}_{\mathrm{ma}}, \mathrm{f}_{\mathrm{du}}$, and $\mathrm{f}_{\mathrm{co}}$. In contrast, the most recent study of this type (Yu et al., 2012a) uses CALIPSO lidar-derived climatology to determine transport height, and accepts that $\mathrm{f}_{\mathrm{ma}}$ varies as a function of latitude and season (Yu et al., 2009b). Furthermore, the backbone of these studies is the MODIS AOD, which has undergone considerable refinement over the 7 -year span of these studies, including the option of selecting a severely cloud-cleared and uncontaminated product (Shi et al., 2011) that was used by Yu et al. (2012a) to correct cloud contamination in AOD.

The satellite-based estimates of aerosol import and export in the zonal direction have offered important insights into aerosol intercontinental transport and its impacts on regional air quality, climate change, and biogeochemical cycle. Kaufman et al. (2005c) estimated that out of the $240 \pm 80 \mathrm{Tg}$ of dust transported annually from Africa to the west, $140 \pm 40 \mathrm{Tg}$ is deposited in the Atlantic Ocean and $50 \pm 15 \mathrm{Tg}$ reaches and fertilizes the Amazon basin. This estimated dust input to the Amazon basin is four times the previous estimate by Swap et al. (1992), which might explain a paradox regarding the source of nutrients for the Amazon forest. Koren et al. (2006) further estimated that about half the annual dust supply to the Amazon basin is emitted from a single, small-area spot, namely the Bodèlè depression, located northeast of Lake Chad. Recently, model sensitivity studies have argued that these estimates may represent the upper bound (Schepanski et al., 2009; Ridley et al., 2012), because of uncertainties associated with the assumed aerosol vertical distributions (Schepanski et al., 2009). On the other hand, model simulations tend to give a lower bound, due to excessive wet removal in models (Ridley et al., 2012; Huneeus et al., 2012).

Trans-Pacific aerosol transport and its contribution to North America have been assessed based on satellite measurements by Yu et al. (2008) and Yu et al. (2012a). Yu et al. (2012a) estimated from MODIS and CALIOP measurements that the annual dust export from East Asia and import to North America is 140 and $56 \mathrm{Tg} \mathrm{yr}^{-1}$, respectively. The trans-Pacific dust transport exhibits large seasonal and meridional variations, as shown in Fig. 6. Also shown in the figure are significant differences between satellite estimate and model simulations. The satellite-based estimate is generally higher than model simulations in regions south of $50^{\circ} \mathrm{N}$, but are lower north of $50^{\circ} \mathrm{N}$. By taking into account the trans-Atlantic dust import (north of $20^{\circ} \mathrm{N}$ ) of $4 \mathrm{Tg} \mathrm{yr}^{-1}$ (Kaufman et al., 2005c) and trans-Pacific pollution import of $4.4 \mathrm{Tg} \mathrm{yr}^{-1}$ (Yu et al., 2008) the total aerosol import to North America is estimated at $64 \mathrm{Tg} \mathrm{yr}^{-1}$. This is comparable to the estimated total (69 $\mathrm{Tg} \mathrm{yr}^{-1}$ ) of domestic emissions and production of aerosols (Yu et al., 2012a).

The air quality impact of imported aerosols in North America is unknown, but may be minor, because the transport occurs predominantly above the boundary layer, as indicated by CALIPSO lidar measurements (Yu et al., 2012a). However, the imported dust and combustion aerosol can have significant impacts on weather and climate. Yu et al. (2012a) used models constrained by their observational results to estimate that dust and combustion aerosols from intercontinental transport collectively introduce a reduction of cloud-free net solar radiation of -1.7 and $-3.0 \mathrm{~W} \mathrm{~m}^{-2}$ at top-of-atmosphere (TOA) and surface, respectively, which represents $31 \%$ and $37 \%$ of the total direct aerosol radiative effect over North America. For comparison, a recent model simulation estimates that the decrease of US anthropogenic aerosols over 1990-2010 yields a decrease of $0.8 \mathrm{~W} \mathrm{~m}^{-2}$ for all-sky direct radiative forcing at TOA (Leibensperger et al., 2012). Besides the aerosol direct radiative effects, the imported aerosols could have other significant impacts, such as changing atmospheric stability by absorbing solar radiation (Yu et al., 2002; Ramanathan and Carmichael, 2008), altering cloud and precipitation processes through acting as ice nuclei (Sassen, 2002; Ault et al., 2011), (a)

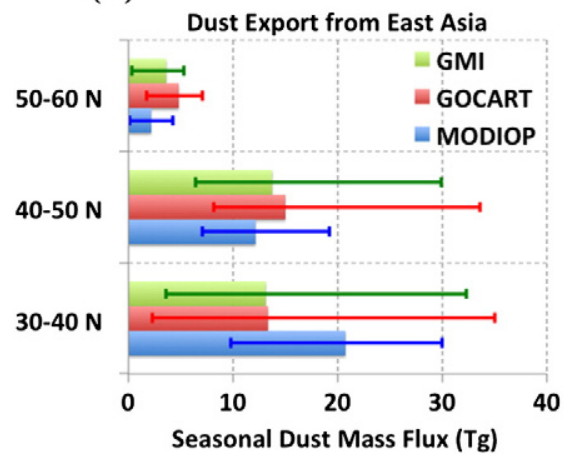

(b)

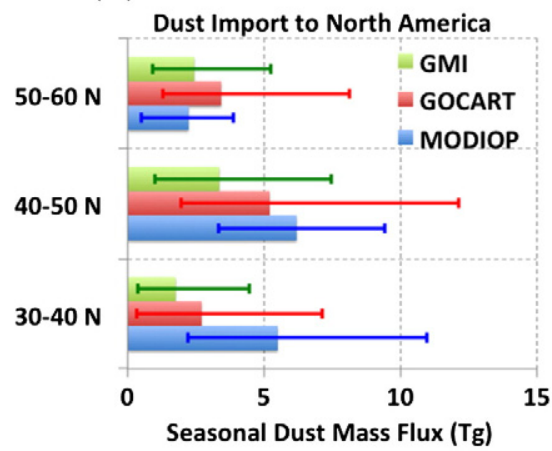

Fig. 6. Meridional variations of seasonal dust mass fluxes exported from East Asia (a) and imported to North America (b) as estimated from MODIS and CALIOP measurements (denoted as MODIOP) and simulated by GOCART and Global Modeling Initiative (GMI) model. The box and bar represents the mean and range of seasonal dust mass fluxes, respectively.

Figure adapted from Yu et al. (2012a). 
Table 3

Comparisons of trans-Pacific dust transport efficiency (a ratio of dust mass flux in North America inflow to that in East Asia outflow) and dust deposition to the North Pacific.

\begin{tabular}{|c|c|c|c|c|}
\hline $\begin{array}{l}\text { Transport } \\
\text { efficiency }\end{array}$ & $\begin{array}{l}\text { Dust deposition } \\
\left(\operatorname{Tg} \mathrm{a}^{-1}\right)\end{array}$ & Region & Notes & Source \\
\hline \multicolumn{5}{|c|}{ Satellite-based estimate } \\
\hline $40 \%$ & 84 & $30^{\circ}-60^{\circ} \mathrm{N}, 140^{\circ} \mathrm{E}-130^{\circ} \mathrm{W}$ & $\begin{array}{l}\text { Deposition estimate should bias high because of the existence of } \\
\text { northward transport to Arctic }\end{array}$ & Yu et al. (2012a) \\
\hline \multicolumn{5}{|c|}{ Estimate based on in-situ measurements } \\
\hline- & 10 & East China Sea only & $\begin{array}{l}\text { Using } 20 \mathrm{~g} \mathrm{~m}^{-2} \mathrm{a}^{-1} \text { deposition rate over the } 0.5 \times 10^{12} \mathrm{~m}^{2} \\
\text { area }\end{array}$ & Hsu et al. (2009) \\
\hline- & $67(18-260)$ & East China Sea only & Estimated based on surface concentration measurements and & Gao et al. (1997) \\
\hline- & 96 & North Pacific & model-based deposition rates & Prospero (1996) \\
\hline- & 480 & North Pacific & & Duce et al. (1991) \\
\hline- & 20 & $0^{\circ}-50^{\circ} \mathrm{N}, 150^{\circ} \mathrm{E}-130^{\circ} \mathrm{W}$ & & Uematsu et al. (1985) \\
\hline \multicolumn{5}{|c|}{ Model simulations } \\
\hline $34 \%$ & 88 & $30^{\circ}-60^{\circ} \mathrm{N}, 140^{\circ} \mathrm{E}-130^{\circ} \mathrm{W}$ & GOCART model; including northward transport to Arctic & Yu et al. (2012a) \\
\hline $25 \%$ & 92 & $30^{\circ}-60^{\circ} \mathrm{N}, 140^{\circ} \mathrm{E}-130^{\circ} \mathrm{W}$ & GMI model; including northward transport to Arctic & Yu et al. (2012a) \\
\hline $40 \%$ & - & $25^{\circ}-55^{\circ} \mathrm{N}, 150^{\circ} \mathrm{E}-130^{\circ} \mathrm{W}$ & 2007 & Su and Toon (2011) \\
\hline $15 \%$ & - & $120^{\circ} \mathrm{E}-120^{\circ} \mathrm{W}$ & For events in mid-August of 2009 & Yumimoto et al. (2010) \\
\hline $30 \%$ & - & $0^{\circ}-70^{\circ} \mathrm{N}, 140^{\circ} \mathrm{E}-120^{\circ} \mathrm{W}$ & For events during May 5-15, 2007 & Eguchi et al. (2009) \\
\hline $43 \%$ & - & $0^{\circ}-90^{\circ} \mathrm{N}, 120^{\circ} \mathrm{E}-120^{\circ} \mathrm{W}$ & Highly lofted (8-10 km) dust event in May 2007 & Uno et al. (2009) \\
\hline $35 \%$ & - & $140^{\circ} \mathrm{E}-130^{\circ} \mathrm{W}$ & Taklimakan dust storm in May 2007 & Yumimoto et al. (2009) \\
\hline- & 68 & North Pacific & 3-model composite; constrained by observations & Jickells et al. (2005) \\
\hline- & 56 & North Pacific & & Tegen et al. (2004) \\
\hline - & 35 & North Pacific & & Luo et al. (2003) \\
\hline- & 64 & $\begin{array}{l}\text { Western North Pacific } \\
(\sim 25 \% \text { of the basin })\end{array}$ & March 1994-May 1995 & Uematsu et al. (2003) \\
\hline - & 31 & North Pacific & & Zender et al. (2003) \\
\hline - & 92 & North Pacific & & Ginoux et al. (2001) \\
\hline
\end{tabular}

and accelerating the melting of snow in the Sierra Nevada by deposition on snow (Hadley et al., 2010). It is possible that a change in meteorological conditions resulting from these processes could further influence surface PM concentrations and air quality. These potential impacts need to be investigated with the state-of-the-science modeling. In addition, it has been observed that increasing level of microorganisms corresponds well to the arrival of dust plumes in the west coast (Smith et al., 2012), which suggests important implication for human health.

The dust deposition into oceans has important implications for ocean biogeochemistry and climate (Jickells et al., 2005; Mahowald et al., 2005). Considering that aerosol meridional transport is generally much weaker than zonal transport, a difference between zonal export and import could be considered as a proxy for aerosol depositional flux into the ocean during the cross-ocean transport. The ratio of import to export flux is generally referred to as "transport efficiency". For the same export in continental outflow, higher transport efficiency generally corresponds to lower aerosol deposition over ocean. Table 3 compares satellite-based estimates of the trans-Pacific dust transport efficiency and dust deposition to the North Pacific (Yu et al., 2012a), with results based on model simulations and in situ observations in the literature. The annual trans-Pacific dust transport efficiency is estimated at about 40\% from MODIS and CALIOP measurements (Yu et al., 2012a), which is at the upper bound of the model simulations listed in Table 3 (15-43\%). Note that the highest model value of $43 \%$ is estimated for an extreme event, where dust was transported rapidly at 8-10 km elevation (Uno et al., 2009), whereas the lowest model value of $15 \%$ was estimated for dust transport in summer, when dust removal from atmosphere is faster and dust transport is slower than in other seasons. The trans-Pacific dust transport efficiency is also reasonably higher than the $26 \%$ for trans-Pacific pollution aerosol estimated from satellite (Yu et al., 2008), because dust is transported at generally higher altitudes than the pollution aerosol (Yu et al., 2012a). Satellite-estimated dust deposition to the North Pacific of $84 \mathrm{Tg} \mathrm{a}^{-1}$ is compared to the estimated range of 31-96 $\mathrm{Tg} \mathrm{a}^{-1}$ in the modeling literature. (These values exclude the highest and lowest estimates from two early studies, as well as two estimates made only over the East China Sea.)

\subsection{Limitations and outlook}

The satellite-estimated mass fluxes are subject to large uncertainties, on an order of 55-100\% (Yu et al., 2008, 2012c). To accurately assess the potentially large impacts of aerosol ICT, the uncertainties represented by the above studies must be significantly reduced. Major sources of uncertainty include satellite-derived component AOD, mass extinction efficiency, hygroscopic properties, transport height, and satellite sampling (Kaufman et al., 2005c; Yu et al., 2008).

The component AOD derived from MODIS measurements entails significantly larger uncertainties than the total AOD. The uncertainties can be reduced through a synergy of multi-sensor measurements from the A-Train (Stephens et al., 2002; Anderson et al., 2005). Aerosol type characterization based on particle size and shape can be cross-examined with trace gas measurements and traced to source locations through the backward trajectory analysis. Such synergy would be particularly 
helpful in regions having complex mixtures of aerosol components. Substantial effort is needed to conduct such synergistic analyses in the future. Radiance measurements from multiple A-Train sensors may be combined to retrieve new information of particle properties and/or improve retrieval accuracy (e.g., Jeong and Hsu, 2008; Satheesh et al., 2009). The process is challenging, and a great deal of effort is needed to explore the possibilities.

Determining seasonally and geographically dependent aerosol vertical profiles or transport heights is another major source of uncertainty in estimating the aerosol mass fluxes (Yu et al., 2008; Schepanski et al., 2009). To calculate mass fluxes, vertical profiles are needed for selecting representative wind speed, and representative $\mathrm{RH}$ to account for particle growth by humidification. The sensitivity of aerosol mass flux to transport height varies with region and season, depending on wind shear patterns and atmospheric humidity profiles. The CALIPSO lidar measurements have recently been used to determine the climatology of aerosol vertical distributions over broad areas with seasonal distinctions (e.g., D. Liu et al., 2008; Huang et al., 2010; Yu et al., 2010,2012a), which provide tighter constraints on the estimated material fluxes. Because of the near-zero swath of CALIPSO lidar, however, it is difficult to examine daily variations of aerosol fluxes. In this regard, aerosol layer heights from passive sensors like AIRS (Peyridieu et al., 2010; DeSouza-Machado et al., 2010) and OMI (Dirksen et al., 2009) can help. Because of CALIPSO's relatively low sensitivity to vertically resolved extinction, some aerosol plumes having moderate AOD but large vertical extent may be missed by the lidar. This drawback can be mediated by suborbital measurements at key locations to calibrate the satellite data sets.

Several satellite-sampling issues also contribute to the uncertainties in the flux estimates. The above studies have only used polar-orbiting satellite measurements, having sampling frequency of no greater than twice per day and being inadequate to characterize the wide range of aerosol diurnal variability (Zhang et al., 2012). An integration of polar orbiting and geostationary satellites could be pursued to characterize the diurnal variations of aerosol export and import.

Current studies have also assumed that dry aerosol mass derived from satellite retrievals in cloud-free conditions is representative of all-sky conditions, even over frontal cloud systems. Unlike in broken cloud fields where satellite retrievals of aerosols are sometimes possible in the gaps between clouds, frontal cloud systems usually extend over wide areas and completely eliminate aerosol retrievals in those areas using current approaches. For example, because the trans-Pacific transport is associated with the warm conveyor belt (WCB), and the WCB is associated with rising air in warm fronts that also produce widespread cloudiness, passive sensors such as MODIS can miss important transport events. If dry aerosol mass in these events is significantly different from that observed under cloud-free conditions, the estimated aerosol flux could have large uncertainties or biases. It has been suggested that a variety of compensating processes in and nearby clouds control the formation and removal of aerosols and hence determine their loading. Although clouds can effectively remove aerosols through scavenging and rainout, they can also generate aerosol (e.g., in-cloud aqueous production of sulfate). Some studies suggest that significant biases may exist in some regions, when satellite measurements only for cloud-free conditions are assimilated into a model (Reid et al., 2004; Zhang and Reid,
2009). Partial constraints on the aerosol load above clouds could be obtained using the emerging satellite observations of AOD above clouds from CALIOP lidar (Winker et al., 2010; Hu et al., 2007; Chand et al., 2008) and even passive sensors like POLDER, OMI, and MODIS (Waquet et al., 2009; Torres et al., 2012; Jethva et al., submitted for publication; Yu et al., 2012b). This new capability needs to be explored.

\section{Satellite evaluation and constraints on model simulations}

The previous sections addressed the contribution that satellites make towards characterizing aerosol ICT when satellite data is used exclusively. Satellites also make a contribution when they work in support of model simulations through three broad paths: (1) characterization of the aerosol sources including location, timing, injection height, and magnitude of emissions, (2) evaluation of aerosol transport simulations, and (3) assimilation of aerosol products into the model for improving model forecasts.

\subsection{Source characterization}

For a model to properly simulate aerosol distribution and transport, it must first incorporate accurate location, timing, and magnitude of particles and gaseous precursor emissions. In comparison to industrial emissions, episodic emissions such as biomass burning smoke from fires and mineral dust from dust storms are more difficult to accurately represent in a model. Correct transport modeling of smoke aerosol is almost entirely dependent on satellite-derived products that either identify and count fire hotspots or more quantitatively measure fire radiative power and relate that to aerosol emissions (Ichoku et al., 2008; Pereira et al., 2009; Reid et al., 2009; Giglio et al., 2010; van der Werf et al., 2010; Ichoku et al., 2012 and references therein; Petrenko et al., 2012). The diurnal pattern of smoke emissions has been determined by applying overpasses at multiple times per day by the twin MODIS sensors on the polar orbiting Terra and Aqua satellites (Vermote et al., 2009; Ichoku et al., 2008), or using geostationary satellite observations (Reid et al., 2004; Zhang and Kondragunta, 2008). For mineral dust, most models rely on satellite data of land surface classification to identify the location of deserts, and a few models use satellite vegetation index data to impose the seasonal variation of the surface bareness for better temporal variation of dust emission (e.g., Zender et al., 2003; Kim et al., 2013). More direct use of satellite AOD for dust emission has also emerged (Koven and Fung, 2008; Schepanski, et al., 2007; Ginoux et al., 2013). Satellite observations have also been used to cap the total emissions of carbonaceous aerosol (Heald et al., 2010).

Satellites also contribute directly to aerosol source characterization through inverse modeling techniques. In these techniques an observed satellite field such as satellite-derived AOD or measured radiances is used in conjunction with a transport model to identify the sources and estimate the emissions that produced the observed field. Examples of this technique include Dubovik et al. (2008), who combined MODIS AOD observations with the GOCART transport model to characterize global aerosol sources of fine particles, Yumimoto et al. (2010) who combined lidar data and model, and Wang et al. (2012) who combined 
MODIS-observed radiances with the GEOS-Chem model, focusing on Asian dust sources.

Because heat from fires can propel particles quickly out of the boundary layer to higher layers of the atmosphere, these particles are sometimes injected into faster-flowing air streams. The resulting transport will be different from a model simulation that fails to consider such fast convective processes and instead leaves the particles in the slower moving boundary layer, where more efficient removal occurs. The importance of injection height has been discussed in context of boreal fire smoke in Canada being transported over the U.S. eastern seaboard (Colarco et al., 2004) and Amazon biomass burning smoke (Freitas et al., 2006). Satellites have made a major contribution here, especially the multi-angle MISR that uses stereo views and parallax to determine the heights of well defined smoke plumes (Kahn et al., 2007, 2008; Scollo et al., 2010; Val Martin et al., 2010), and CALIOP that provides vertical aerosol profiles (Amiridis et al., 2010). These products offer models information on injection heights for specific cases. The two products are complementary, as MISR provides greater coverage than the curtain-wide CALIOP, whereas CALIOP offers greater details in the vertical and provides the height of smoke after it becomes diffuse (Kahn et al., 2008). Val Martin et al. (2010) pushed one step beyond the individual case studies by establishing a climatology of injection heights using five years of MISR data over North America, as shown in Fig. 7. This climatology linked the $4-12 \%$ of the plumes that permeated the boundary layer, based on MISR data, with specific meteorological conditions and with higher fire radiative power measured by the MODIS sensor. Guan et al. (2010) found a linear relationship between coincident OMI AAI and CALIOP plume height for young biomass burning plumes, allowing the identification of high-altitude plumes in the multi-decadal TOMS and OMI AAI data, and hence making it possible to construct a data set for validating global fire plume heights in chemistry transport models. These associations from satellite products, begin to give the modeling community the information they need to develop and refine plume rises models, so smoke from fires can be placed at the correct altitude within the model, thus improving aerosol transport modeling (Sessions et al., 2011; Val Martin et al., in press). Injection heights have been characterized by satellite also for dust plumes (Kahn et al., 2007; Yumimoto et al., 2009) and volcanic plumes (Haywood et al., 2010; Scollo et al., 2010).

\subsection{Model evaluation}

Satellite observations of AOD and vertical distributions have been used extensively to evaluate model simulations, which in many cases is the best way to bound model estimates of aerosol transport. One of the earliest uses of satellites to evaluate model simulations of aerosol transport was Tegen et al. (1997) who showed both the advantages and challenges of matching model results with satellite products, in their case AOD from AVHRR. Their comparisons revealed both model inaccuracies and retrieval problems. Other studies followed, to the point that model comparison against satellite AOD has become an almost standard requirement. In the 1990s and early 2000s, the comparisons relied on the TOMS and AVHRR products (e.g., Chin et al., 2002) or simple imagery (Colarco et al., 2003). When EOS-era aerosol satellite products became available, studies made use of the new, more quantitative products, mostly MODIS AOD, but also MISR AOD over land and ocean (Chin et al., 2004; Heald et al., 2006; Colarco et al., 2010; Ford and Heald, 2012; Ridley et al., 2012). Evaluation can also include comparison of Angstrom Exponent or size parameter (Colarco et al., 2010) and anthropogenic component of AOD (Yu et al., 2009b, 2013). A composite of multiple satellite products, pre- and post-EOS era, became the standard to which the AEROCOM ensemble of models was held (Kinne et al., 2006). Then with the addition of CALIOP, the ability to evaluate the vertical distribution of aerosol became possible (Generoso et al., 2008; Yu et al., 2010; Koffi et al., 2012; Ridley et al., 2012).

Comparisons of model simulations against satellite observations can provide valuable hints for improving model representations of crucial processes such as aerosol scavenging removal (Bourgeois and Bey, 2011; Nowottnick et al., 2011; Ridley et al., 2012) and the rise of smoke plumes (Sessions et al., 2011; Dirksen et al., 2009). Ridley et al. (2012) demonstrate the extent to which a suite of satellite products can be used to evaluate a model's ability to simulate aerosol transport, in this case multiyear Saharan dust transport over the Atlantic. The model is shown to capture the variability of these dust plumes by correlation with MODIS and MISR and to match the vertical distribution of the plumes as they exit the African continent by quantitative comparison with CALIOP. They also find that the lifetime of the simulated dust is a few days shorter than that observed from satellite. Comparison of model rain rates with TRMM satellite-derived rain rates shows that wet deposition in

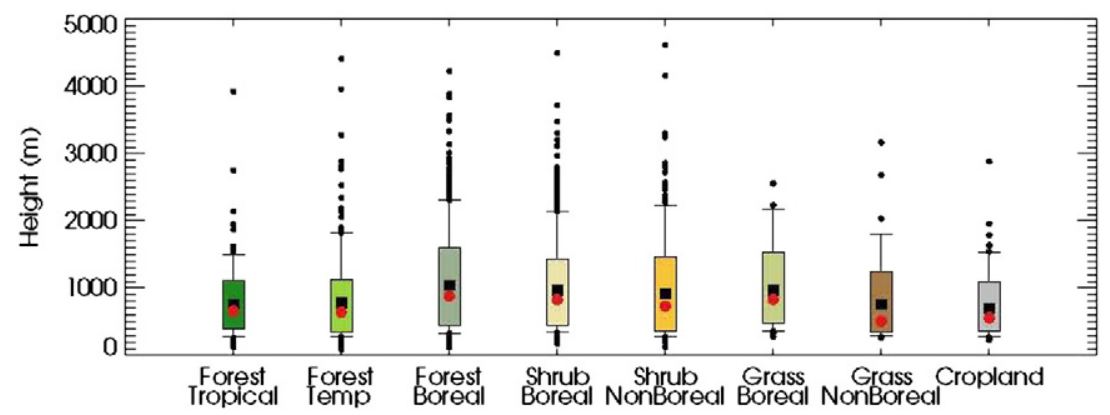

Fig. 7. MISR observed smoke plume heights (above the ground level) in each biome over North America in 2002, and 2004-2007. Bar plots indicate the distribution of the data. The medians (red circles) and the means (black squares) are shown along with the central 67\% (color coded box) and the central 95\% (thin black lines). Data that fall outside the bar plots are plotted with black circles.

Figure taken from Val Martin et al. (2010), with permission from Atmospheric Chemistry and Physics. 


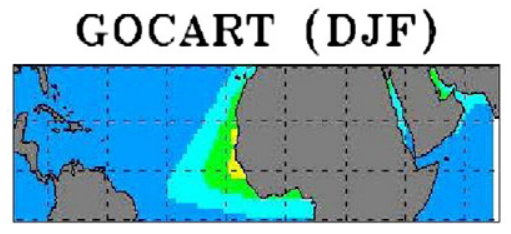

\section{GOCART (MAM)}

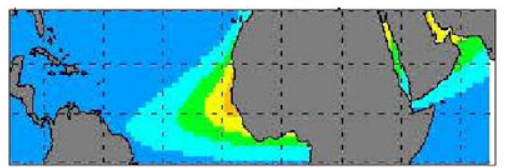

GOCART (JJA)

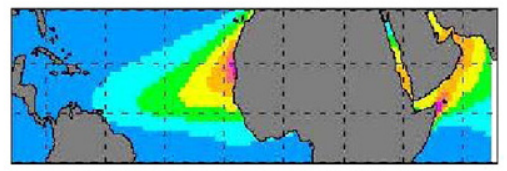

\section{GOCART (SON)}
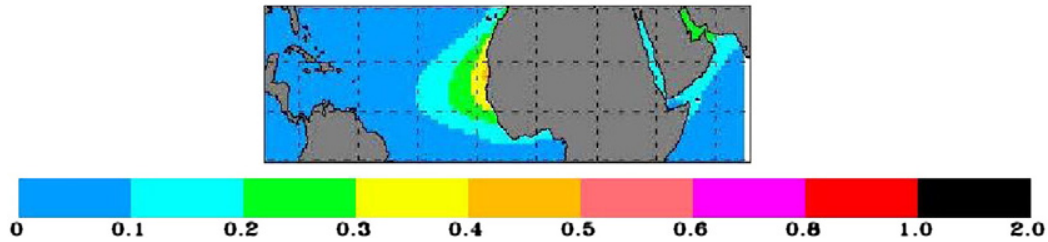

Fig. 8. GOCART simulations of seasonal-mean dust AOD in the tropical Atlantic.

the model is too strong. On the other hand, Nowottnick et al. (2011) show that more aggressive wet removal of dust over the Caribbean in their model is needed to reproduce the barrier to dust transport across Central America into the eastern Pacific observed by MODIS. Dirksen et al. (2009) compare model simulations with satellite measurements of a smoke plume released by intense forest fires in Australia that circumnavigated the world in 12 days, which suggests the need to include the effect of pyro-convective lofting and the effect of smoke absorption on the atmospheric thermodynamics in global models.

Fig. 8 shows GOCART simulations of seasonal cross-ocean transport of African dust. In comparison to satellite measurements shown in Fig. 5, the modeled dust transport generally drifts southward in summer and decays more rapidly (i.e., weak transport efficiency). Such differences are apparently not limited to the GOCART model, as several other models show similar deviations from satellite observations (e.g., Generoso et al., 2008; Huneeus et al., 2012; Ridley et al., 2012). Reasons for such observation-model discrepancies are not yet fully understood. It has been argued that model treatment of aerosol removal processes needs to be improved (Generoso et al., 2008; Prospero et al., 2010; Huneeus et al., 2012; Ridley et al., 2012). Dust can influence the cross-ocean transport, through its feedbacks on atmospheric circulations and the water cycle, that are not accounted for in most CTMs. For example, Lau et al. (2009) found that dust absorption can enhance rainfall and cloudiness over the West Africa and Eastern Atlantic Intercontinental Convergence Zone (ITCZ), but suppresses rainfall and cloudiness and rainfall over the West Atlantic and Caribbean region. Wilcox et al. (2010) found that Saharan dust outbreaks coincide with a northward shift of the North Atlantic Ocean ITCZ in summer. If these feedbacks and coincidences are supported by independent observations and can be reproduced by aerosol models, the modeled summertime cross-ocean transport would have shifted northward and the transport efficiency or the gradient of dust AOD between the East and West Atlantic would increase.

\subsection{Integrated approach}

Integrating satellite measurements and aerosol transport models is necessary for a comprehensive characterization of aerosol intercontinental transport. On one hand, satellite measurements provide observational evidence of aerosol intercontinental transport that can be quantitative (Sections 2 and 3 ). However, these observations are restricted by limited satellite capabilities such as observing only once or twice daily, and for most sensors, only under cloud-free conditions. Space-borne lidars add an essential third dimension to the characterization, but lidars are limited by extremely narrow swaths and poor spatial sampling. On the other hand, model simulations offer a much more comprehensive picture of aerosol intercontinental transport by providing multi-dimensional characteristics of 
aerosol in a continuous manner, including clearly distinguishing by aerosol species. But they are limited by imperfect knowledge of source attributes and the models' imperfect ability to simulate

(a)

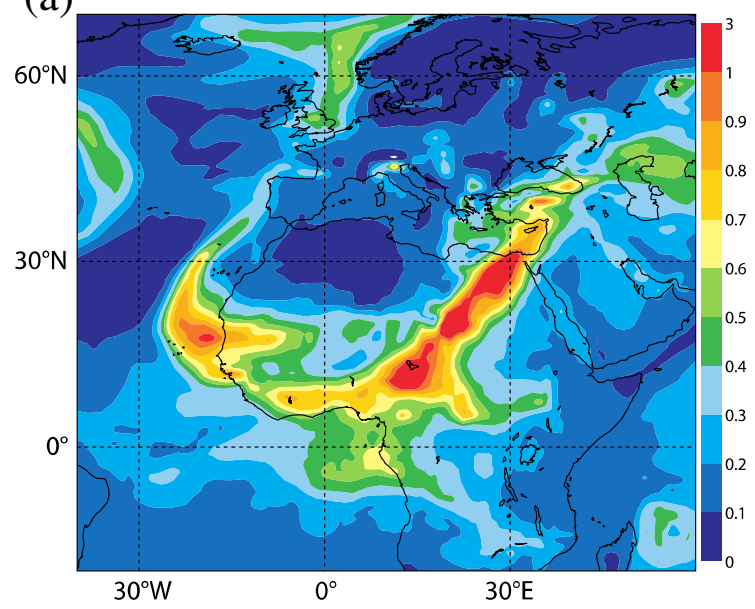

(b)

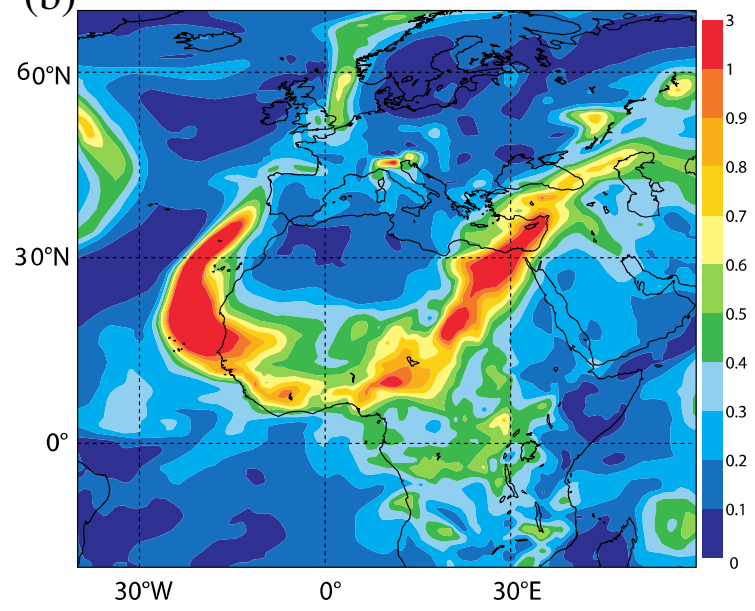

(c)

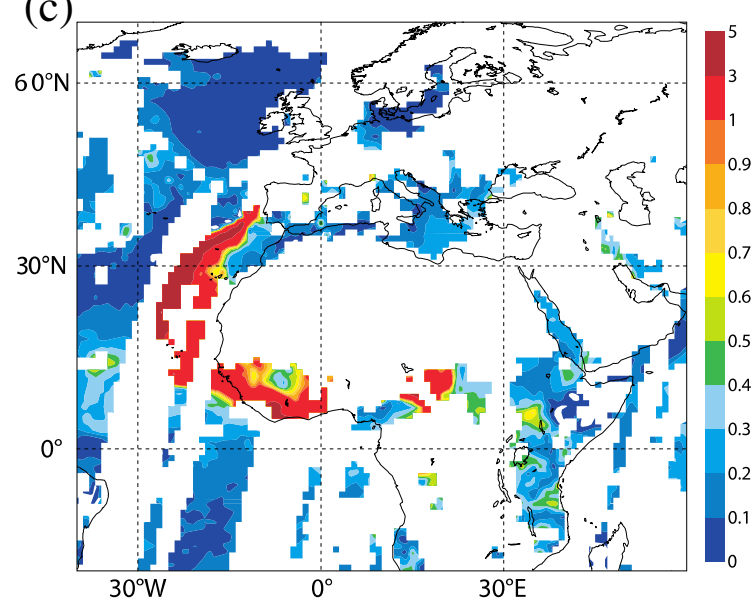

physical and chemical processes in the atmosphere. A number of studies have used this satellite-model integrated analysis approach to characterize the intercontinental transport of dust
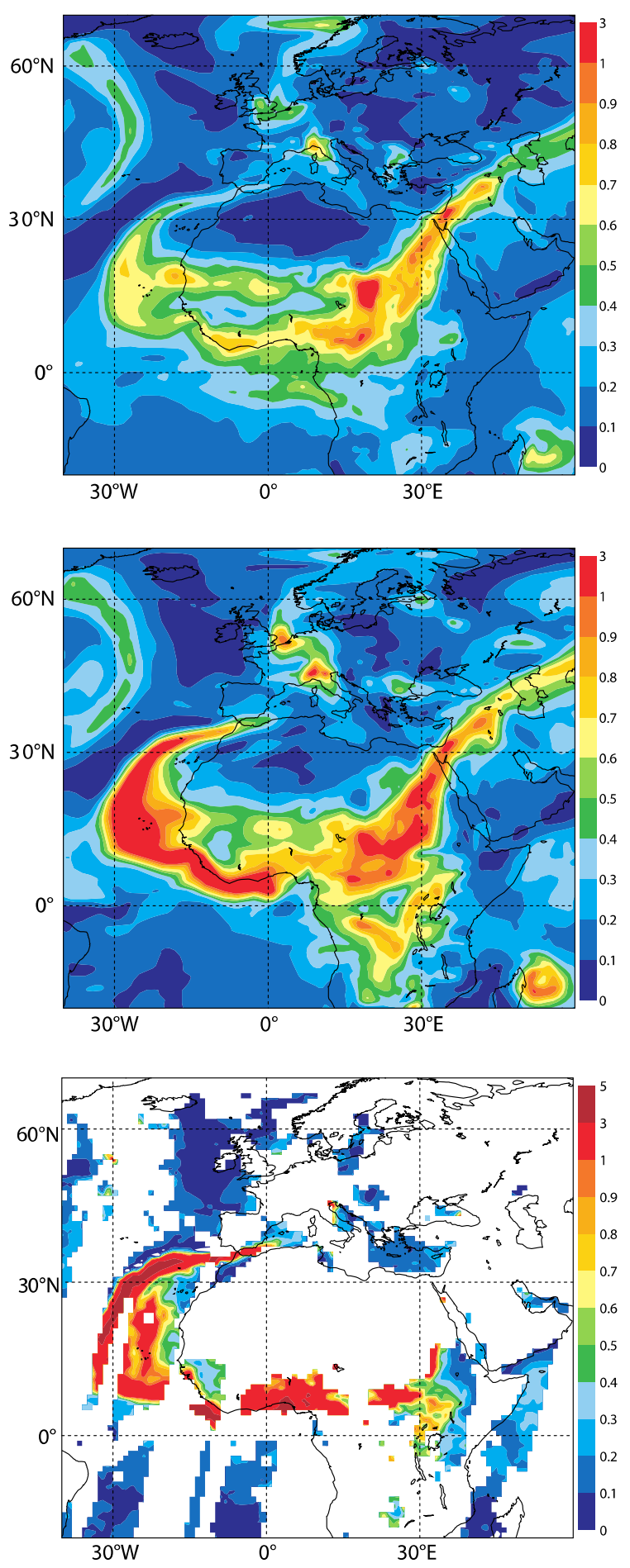

Fig. 9. AOD (at $550 \mathrm{~nm}$ ) distributions of March 2004 Saharan dust outbreak as simulated by the ECMWF model: (a) free-running model, (b) assimilation with MODIS observations, and (c) MODIS observations for (left) 5 March 2004 at 1200 UTC and (right) 6 March 2004 at 1200 UTC. Figure taken from Benedetti et al. (2009), with permission from American Geophysical Union. 
and pollution aerosol (Eguchi et al., 2009; Hara et al., 2009; Itahashi et al., 2010; Uno et al., 2008, 2009, 2011; Yumimoto et al., 2009, 2010).

Satellite aerosol products can be assimilated into run-time models to actively nudge models towards real-world conditions, often producing better representation of the aerosol field and aerosol transport. This is especially useful for real-time aerosol forecasting. One of the earliest examples of aerosol assimilation involved the Model of Atmospheric Transport and Chemistry (MATCH) and how it was applied to the INDOEX experiment in 1999 (Collins et al., 2001). The model was run to produce an aerosol field, then that field was adjusted to better resemble the AOD as derived from AVHRR satellite observations. The assimilated results show much closer agreement to the sunphotometer measurements. The assimilation provided aerosol information when satellite retrievals were impossible: at night and in cloudy situations (Rasch et al., 2001). In recent years, other modeling groups have assimilated EOS-era satellite aerosol information for real-time aerosol forecasting. MODIS aerosol optical depth, over land and ocean, is automatically ingested and assimilated into the European Centre for Medium Range Forecasting (ECMWF) for aerosol predictions (Benedetti et al., 2009). Fig. 9 shows comparisons between AODs from the free-running ECMWF model and the ECMWFMODIS analysis compared to MODIS observations for 5-6 March 2004 Saharan dust outbreak. Although the satellite observed shape of the dust outflow is well represented in the free-running model, the magnitude of the AODs is much lower than both MODIS and AERONET measurements (not shown here). The assimilation yields much better agreement with AERONET measurements.

MODIS aerosol optical depth is also assimilated into the Naval Research Laboratory (NRL) Atmospheric Variational Data Assimilation System (NAVDAS) over ocean (Zhang et al., 2008) and is being prepared for assimilation over land (Hyer et al., 2011). Likewise, CALIOP vertical profiles (Campbell et al., 2010) and MISR-derived aerosol properties have also been assimilated into the same system. By adding these satellite data products, model forecasts and aerosol transport results were quantitatively improved (Zhang et al., 2011). Other assimilation studies include Yumimoto and Takemura (2011) who assimilated one month of Terra and Aqua MODIS AOD. Studies have also used satellite products to constrain model simulations through diagnostic analysis (Yu et al., 2003; Matsui et al., 2004; H. Liu et al., 2005). However, data assimilation and analysis currently provide more total AOD than component AOD constraints, due to the lack of accurate, global aerosol type products from satellites.

Satellite measurements can also be integrated with model systems to assess the influences of aerosol intercontinental transport on atmospheric composition, air quality, weather, and climate. Over ocean, the intercontinental transport of continental aerosols can often be distinguished from relatively clean marine aerosols and the interactions of aerosols with cloud and precipitation may be inferred from a correlative analysis of satellite measured aerosols, clouds, and precipitation (e.g., Kaufman et al., 2005d; Koren et al., 2005; Zhang et al., 2007), though significant uncertainty still applies. Over land, however, distinguishing ICT aerosols from local sources remains a great challenge for satellite remote sensing. Aerosols from different continents usually have similar characteristics; and current satellites are not capable of discerning the usually marginal differences between continents. Thus assessing the impacts of aerosol ICT on air quality, weather, and climate in downwind continents has to rely on model systems that link important atmospheric processes at local, regional, and hemispheric scales. Global models are needed to provide regional models with appropriate boundary and initial conditions, whereas regional models having higher resolution are needed to adequately represent major chemical and meteorological processes important for air quality, weather, and climate. Considering large uncertainties associated with global aerosol models, measurements from satellites should be used to provide chemical boundary conditions of aerosol ICT for regional models and hence reduce the model spread shown in Fig. 1.

\section{Conclusions and outlook}

Satellites provide ideal platforms for studying aerosol intercontinental transport, because of the frequent sampling over global and multi-year scales. In the last decade or two, major advances have been achieved in both passive and active aerosol remote sensing from space, providing better coverage, higher spatial resolution, improved AOD accuracy, emerging climatology of vertical distributions, and enhanced capabilities to characterize aerosol type, as provided by observational constraints on particle properties. Satellites also provide correlative measurements of trace gases, as well as the strengths and properties of aerosol sources. These advances offer unprecedented opportunities to develop a measurement-based assessment of aerosol intercontinental transport.

The accumulation of advanced satellite observations over the past decade has significantly improved the understanding of aerosol intercontinental transport, from largely qualitative characterization to increasingly quantitative assessment. The observations have been used to characterize the threedimensional evolution of aerosol loading and particle properties (size, and shape) during intercontinental transport on an episodic basis. Long-term measurements with daily frequency have been used to characterize seasonal and inter-annual variations of aerosol ICT and associated controlling factors. Most recently, estimates of aerosol export and import have been performed using the satellite measurements of aerosol optical depth, vertical distribution, and microphysical properties over ocean. The findings have important implications for air pollution control and climate mitigation.

Measurement-based quantitative assessment of aerosol ICT requires a synthesis of multiple data sets. No sensor, known or expected in the foreseeable future, has sufficient capability to fully characterize aerosol ICT in the level-of-detail of greatest interest without additional information. For example, MODIS offers among the most complete coverage, which is essential to capturing specific transport events and good longer-term statistics, but cannot directly identify transport height or aerosol type. MISR provides much better characterization of aerosol particle properties and how those evolve along the transport path, but has a more limited sampling. CALIOP is the ideal instrument to identify transport height and can distinguish dust from combustion aerosol, but is extremely limited in its sampling. The other satellite sensors also each make their own specific contributions. Combining information from different sensors is shown to provide quantitative estimates of the 
material flux imported and exported at continental boundaries, albeit still with large error bars. Narrowing these error bars requires continued characterization of the aerosol using additional data sets and new validated products from the current suite of satellite sensors (i.e., more accurate particle properties, AOD above clouds). In turn, validation of the satellite data sets, as well as obtaining detailed information about particle microphysical properties, requires a concerted effort from suborbital observations.

In addition to the satellite-alone observation-based applications, satellite measurements have also provided several critical inputs for constraining chemical transport models, and valuable datasets for evaluating and improving model simulations of aerosol intercontinental transport. The ultimate means to quantify aerosol ICT will necessarily involve a combination of multiple satellite observations and models. This may take the form of directly assimilating satellite aerosol products into models, or constraining models with observational results. These constraints amount to more than just requiring the model to match the satellite-derived AOD, or even the satellitederived particle properties. The models also need to simulate the satellite-derived material fluxes into and out of continents at the continental boundaries. It is recommended that AeroCom and HTAP model experiments consider including the export/ import flux requirement into their data protocols, so that models can be evaluated with satellite observations.

Despite this significant progress, substantial effort is needed in the future to fully explore the potential offered by existing satellites, and to develop new and enhanced satellite missions:

(a) Geostationary satellite measurements have been underused. Aerosols can have a wide range of diurnal variations, depending on location and season (Zhang et al., 2012). Although geostationary measurements usually do not have adequate spatial coverage to track the evolution of aerosol plumes along the entire intercontinental transport path, in combination with polar orbiting satellite measurements they can provide the hour-to-hour evolution of the plumes in many regions of interest.

(b) Satellite-based studies should extend to all major ICT paths. The trans-Atlantic transport of Saharan dust has been well studied, and there are studies addressing the trans-Pacific transport of dust and pollution. However, except for a few efforts, the Indian Ocean, the Southern Hemisphere, pollution transport from North America and Europe have not received much attention in observationally based work.

(c) More information can be extracted from existing sensors. The integrated use of multiple satellite measurements can potentially improve the characterization of aerosol temporal and spatial distribution, distinguish aerosol types and overcome uncertainties introduced by sampling issues. In particular, integration of non-aerosol products such as carbon monoxide and $\mathrm{SO}_{2}$ gas can add valuable information, but is mostly missing from current studies. Novel analysis techniques that include combining absorption Angstrom exponent and extinction Angstrom exponent for better aerosol type characterization (Russell et al., 2010) or retrieving AOD from above clouds using passive sensors (Waquet et al., 2009;
Torres et al., 2012; Yu et al., 2012b) could also aid in improving assessment of aerosol ICT from satellite measurements alone.

(d) Satellite products require suborbital validation. As more information is extracted from existing sensors, these new products require validation that only suborbital measurements can supply. Validation has to go beyond comparing AOD with AERONET, to collect more coincident, detailed particle property measurements from airborne and ground-based instruments, and use them to test satellite retrieval results.

(e) Continuity and enhancement of satellite capabilities. Now that we are fully exploiting the information content and synergy of the EOS-era satellites, we note that these sensors are aging and are operating almost a decade beyond their initial mission lifetimes. New and future satellites (i.e., Suomi-NPP VIIRS, GOES-R ABI, the Earthcare suite of sensors) can continue some, but far from all EOS-era capability. Key to future abilities is the Earthcare ATLID, a lidar to succeed CALIOP, although its different spectral configuration raises questions of continuity. We are missing a next-generation multi-angle, polarimeter imager that can provide the detailed particle properties we have come to expect from MISR and POLDER.

(f) Consequences of aerosol ICT should be explored. What is the radiative effect of this transport over oceans and over continents? What is the effect on air quality? How are these consequences partitioned between dust and combustion aerosols? How much is anthropogenic and how much is natural? The answers to these questions will require a synthesized combination of multiple observation systems and multi-scale models. However, satellite-based observations can take a leading role, and make significant quantitative contribution to finding the answer to these important questions.

(g) Satellite-based assessments alone are insufficient to answer all the questions. Modeling studies will be necessary, but models must use the information gained by satellite studies to constrain emissions, evaluate AOD distributions and compare with import/export assessments at continental boundaries. Assimilation provides one way forward, but sacrifices the ability of the model studies to understand aerosol processes in the atmosphere through the exercise of modeling/evaluation/ model improvement. A global-regional modeling system is needed, with global model providing regional model with appropriate boundary conditions and regional model with higher resolution for adequately representing major chemical and dynamical processes important for air quality, weather, and climate.

Acronyms

AAI Absorbing Aerosol Index (sometimes as AI)

AATSR Advanced Along-Track Scanning Radiometer

ABL Atmospheric Boundary Layer

ACA Above Cloud Aerosol

ADEOS Advanced Earth Observing Satellite

AE Angstrom Exponent

AEROCOM Aerosol Comparisons between Observations and Models 
AERONET AErosol RObotic NETwork

AIRS Atmospheric Infrared Sounder

AOD Aerosol Optical Depth

ATLID Atmospheric Lidar

ATSR Along Track Scanning Radiometer

AVHRR Advanced Very High Resolution Radiometer

CALIOP Cloud-Aerosol Lidar with Orthogonal Polarization

CALIPSO Cloud-Aerosol Lidar and Infrared Pathfinder Satellite Observations

CTM Chemical Transport Model

ECMWF European Centre for Medium Range Forecasting

EOS Earth Observing System

EP Earth Probe

ERS European Remote Sensing

FMF Fine Mode Fraction (aerosol)

GEOS-Chem Goddard Earth Observing System (GEOS) Chemistry model

GLAS Geoscience Laser Altimeter System

GMI Global Modeling Initiative

GOCART Goddard Chemistry Aerosol Radiation and Transport model

GOES Geostationary Operational Environmental Satellites

GOME Global Ozone Monitoring Experiment

HTAP Hemispheric Transport of Air Pollutants

HYSPLIT Hybrid Single Particle Lagrangian Integrated Trajectory Model

IASI Infrared Atmospheric Sounding Interferometer

ICT InterContinental Transport

INDOEX Indian Ocean Experiment

ITCZ Inter-Tropical Convergence Zone

LH Layer Height (aerosol)

MAN Marine Aerosol Network

MATCH Model of Atmospheric Transport and Chemistry

MERIS MEdium Resolution Imaging Spectrometer

MISR Multi-angle Imaging SpectroRadiometer

MJO Madden-Julian Oscillation

MODIS Moderate Resolution Imaging Spectroradiometer

MSG Meteosat Second Generation

NAO North Atlantic Oscillation

NAVDAS NRL Atmospheric Variational Data Assimilation System

NPP NPOESS Preparatory Project

NRC National Research Council

NRL Naval Research Laboratory

NSF Non-Spherical Fraction (aerosol)

OMI Ozone Monitoring Instrument

PARASOL Polarization and Anisotropy of Reflectances for Atmospheric Sciences Coupled with Observations from a Lidar

PM Particulate Matter

POLDER Polarization and Directionality of the Earth's Reflectance

RAIR Relative Annual Intercontinental Response

RH Relative Humidity

SCIAMACHY Scanning Imaging Absorption Spectrometer for Atmospheric Chartography/Chemistry

SeaWiFS Sea-viewing Wide Field-of-view Sensor

SEVIRI Spinning Enhanced Visible Infra-Red Imager

SSA Single-Scattering Albedo (aerosol)

TOA Top-Of-Atmosphere

TOMS Total Ozone Mapping Spectrometer
TRMM Tropical Rainfall Measuring Mission

UV Ultra-violet (radiation)

VIIRS Visible Infrared Imaging Radiometer Suite

VISSR Visible/Infrared Spin Scan-Radiometer

VP Vertical Profile (aerosol)

WCB Warm Convey Belt

\section{Acknowledgments}

HY, LAR, MC, and YZ acknowledge the NASA support of this work via NNXAH66G (The Science of Terra and Aqua program) and NNX11AJ91G (Atmospheric Composition Modeling and Analysis - ACMAP program), both managed by Richard Eckman. MC was also supported in part by NASA Modeling, Analysis, and Projection program managed by David Considine. The work of RK was supported in part by NASA's Climate and Radiation Research and Analysis Program under Hal Maring, ACMAP program under Richard Eckman, and the EOS-MISR instrument project. We thank anonymous reviewers for insightful comments that have helped improve the quality of the paper.

\section{Appendix A. Supplementary material}

Supplementary data to this article can be found online at http://dx.doi.org/10.1016/j.atmosres.2012.12.013.

\section{References}

Abdou, W.A., Diner, D.J., Martonchik, J.V., Bruegge, C.J., Kahn, R.A., Gaitley, B.J., Crean, K.A., 2005. Comparison of coincident MISR and MODIS aerosol optical depths over land and ocean scenes containing AERONET sites. J. Geophys. Res. 110, D10S07. http://dx.doi.org/10.1029/2004JD004693.

Acarreta, J.R., De Haan, J.F., Stammes, P., 2004. Cloud pressure retrieval using the $\mathrm{O}_{2}-\mathrm{O}_{2}$ absorption band at $477 \mathrm{~nm}$. J. Geophys. Res. 109, D05204. http://dx.doi.org/10.1029/2003JD003915.

Ahn, C., Torres, O., Bhartia, P.K., 2008. Comparison of ozone monitoring instrument UV aerosol products with aqua/moderate resolution imaging spectroradiometer and multiangle imaging spectroradiometer observations in 2006. J. Geophys. Res. 113, D16S27. http://dx.doi.org/10.1029/ 2007JD008832.

Albrecht, B., 1989. Aerosols, cloud microphysics, and fractional cloudiness. Science 245, 1227-1230.

Al-Saadi, J., et al., 2005. Improving national air quality forecasts with satellite aerosol observations. Bull. Am. Meteorol. Soc. 86, 1249-1261.

Amiridis, V., Giannakaki, E., Balis, D.S., Gerasopoulos, E., Pytharoulis, I., Zanis, P., Kazadzis, S., Melas, D., Zerefos, C., 2010. Smoke injection heights from agricultural burning in Eastern Europe as seen by CALIPSO. Atmos. Chem. Phys. 10, 11567-11576. http://dx.doi.org/10.5194/acp-10-115672010.

Anderson, T.L., Charlson, R.J., Bellouin, N., Boucher, O., Chin, M., Christopher, S.A., Haywood, J., Kaufman, Y.J., Kinne, S., Ogren, J.A., Remer, L.A., Takemura, T., Tanré, D., Torres, O., Trepte, C.R., Wielicki, B.A., Winker, D.M., Yu, H., 2005. An "A-Train" strategy for quantifying direct aerosol forcing of climate. Bull. Am. Meteorol. Soc. 86 (12), 1795-1809.

Ansmann, A., Baars, H., Tesche, M., Müller, D., Althausen, D., Engelmann, R., Pauliquevis, T., Artaxo, P., 2009. Dust and smoke transport from Africa to South America: lidar profiling over Cape Verde and the Amazon rainforest. Geophys. Res. Lett. 36, L11802. http://dx.doi.org/10.1029/ 2009GL037923.

Ault, A.P., Williams, C.R., White, A.B., Neiman, P.J., Creamean, J.M., Gaston, C.J., Ralph, F.M., Prather, K.A., 2011. Detection of Asian dust in California orographic precipitation. J. Geophys. Res. 116, D16205. http://dx.doi.org/ 10.1029/2010JD015351.

Barnaba, F., Gobbi, G.P., 2001. Lidar estimation of tropospheric aerosol extinction, surface area and volume: maritime and desert-dust cases. J. Geophys. Res. 106 (D3), 3005-3018. http://dx.doi.org/10.1029/2000JD900492.

Ben-Ami, Y., Koren, I., Altaratz, O., 2009. Patterns of North African dust transport over the Atlantic: winter vs. summer, based on CALIPSO first 
year data. Atmos. Chem. Phys. 9, 7867-7875. http://dx.doi.org/10.5194/ acp-9-7867-2009.

Ben-Ami, Y., Koren, I., Rudich, Y., Artaxo, P., Martin, S.T., Andreae, M.O., 2010. Transport of North African dust from the Bodele depression to the Amazon Basin: a case study. Atmos. Chem. Phys. 10, 7533-7544. http:// dx.doi.org/10.5194/acp-10-7533-2010.

Ben-Ami, Y., Koren, I., Altaratz, O., Kostinski, A., Lehahn, Y., 2012. Discernible rhythm in the spatio/temporal distributions of transatlantic dust. Atmos. Chem. Phys. 12, 2253-2262.

Benedetti, A., Morcrette, J.-J., Boucher, O., Dethof, A., Engelen, R.J., Fisher, M., Flentje, H., Huneeus, N., Jones, L., Kaiser, J.W., 2009. Aerosol analysis and forecast in the European Centre for Medium-Range Weather Forecasts Integrated Forecast System: 2. Data assimilation. J. Geophys. Res. 114, D13205. http://dx.doi.org/10.1029/2008JD011115.

Bian, H., Chin, M., Kawa, R., Yu, H., Diehl, T., Kucsera, T., 2010. Multi-scale carbon monoxide and aerosol correlations from satellite measurements and GOCART model: implication for emissions and atmospheric evolution. J. Geophys. Res. 115, D07302. http://dx.doi.org/10.1029/2009JD012781.

Biscaye, P., Grousset, F.E., Svensson, A.M., Bory, A., 2000. Eurasian air pollution reaches eastern North America. Science 290, 2258-2259. http://dx.doi.org/ 10.1126/science.290.5500.2258.

Bourgeois, Q., Bey, I., 2011. Pollution transport efficiency toward the Arctic: sensitivity to aerosol scavenging and source regions. J. Geophys. Res. 116, D08213. http://dx.doi.org/10.1029/2010JD015096.

Campbell, J.R., Reid, J.S., Westphal, D.L., Zhang, J., Hyer, E.J., Welton, E.J., 2010. CALIOP aerosol subset processing for global aerosol transport model data assimilation. IEEE J. Sel. Topics Appl. Earth Observ. Remote Sens. 3. http://dx.doi.org/10.1109/JSTARS.2010.2044868.

Chameides, W.L., Yu, H., Liu, S.C., et al., 1999. A case study of the effects of atmospheric aerosols and regional haze on agriculture: an opportunity to enhance crop yields in China through emission controls? Proc. Natl. Acad. Sci. 96, 13626-13633.

Chand, D., Anderson, T.L., Wood, R., Charlson, R.J., Hu, Y., Liu, Z., Vaughan, M., 2008. Quantifying above-cloud aerosol using spaceborne lidar for improved understanding of cloudy-sky direct climate forcing. J. Geophys. Res. 113, D13206. http://dx.doi.org/10.1029/2007JD009433.

Chen, W.-T., Kahn, R., Nelson, D., Yau, K., Seinfeld, J., 2008. Sensitivity of multi-angle imaging to optical and microphysical properties of biomass burning aerosols. J. Geophys. Res. 113, D10203. http://dx.doi.org/10.1029/2007JD009414.

Chiapello, I., Moulin, C., Prospero, J.M., 2005. Understanding the long-term variability of African dust transport across the Atlantic as recorded in both Barbados surface concentrations and large-scale Total Ozone Mapping Spectrometer (TOMS) optical thickness. J. Geophys. Res. 110, D18S10. http://dx.doi.org/10.1029/2004JD005132.

Chin, M., Ginoux, P., Kinne, S., Torres, O., Holben, B.N., Duncan, B.N., Martin, R.V., Logan, J.A., Higurashi, A., Nakajima, T., 2002. Tropospheric aerosol optical thickness from the GOCART model and comparisons with satellite and sunphotometer measurements. J. Atmos. Sci. 59, 461-483.

Chin, M., Chu, A., Levy, R., Remer, L.A., Kaufman, Y.J., Holben, B.N., Eck, T., Ginoux, P., Gao, Q., 2004. Aerosol distribution in the Northern Hemisphere during ACE-Asia: results from global model, satellite observations, and Sun photometer measurements. J. Geophys. Res. 109, D23S90. http://dx.doi.org/10.1029/2004JD004829.

Chin, M. Diehl, T, Ginoux, P. Malm, W. 2007. Intercontinental transport of pollution and dust aerosols: implications for regional air quality. Atmos. Chem. Phys. 7, 5501-5517. http://dx.doi.org/10.5194/acp-7-5501-2007.

Chu, D.A., Kaufman, Y.J., Ichoku, C., Remer, L.A., Tanre, D., Holben, B.N., 2002. Validation of MODIS aerosol optical depth retrieval over land. Geophys. Res. Lett. 29. http://dx.doi.org/10.1029/2001GLO13205.

Chung, Y.S., 1986. Air pollution detected by satellites: the transport and deposition of air pollutants over oceans. Atmos. Environ. 20, 617-630.

Colarco, P.R., et al., 2003. Saharan dust transport to the Caribbean during PRIDE: 2. Transport, vertical profiles, and deposition in simulations of in situ and remote sensing observations. J. Geophys. Res. 108, 8590. http:// dx.doi.org/10.1029/2002JD002659.

Colarco, P.R., Schoeberl, M.R., Doddridge, B.G., Marufu, L.T., Torres, O., Welton, E.J., 2004. Transport of smoke from Canadian forest fires to the surface near Washington, D.C.: injection height, entrainment, and optical properties. J. Geophys. Res. 109, D06203. http://dx.doi.org/10.1029/2003JD004248.

Colarco, P., da Silva, A., Chin, M., Diehl, T., 2010. Online simulations of global aerosol distributions in the NASA GEOS-4 model and comparisons to satellite and ground-based aerosol optical depth. J. Geophys. Res. 115, D14207. http://dx.doi.org/10.1029/2009JD012820.

Collins, W.D., Rasch, P.J., Eaton, B.E., Khattatov, B.V., Lamarque, J.-F., Zender, C.S., 2001. Simulating aerosols using a chemical transport model with assimilation of satellite aerosol retrievals: methodology for INDOEX. J. Geophys. Res. 106 (D7), 7313-7336. http://dx.doi.org/10.1029/2000JD900507.

Damoah, R., et al., 2004. Around the world in 17 days - hemispheric-scale transport of forest fire smoke from Russia in May 2003. Atmos. Chem. Phys. 4, 1311-1321.
DeSouza-Machado, S., Strow, L.L., Motteler, H., Hannon, S., 2006. Infrared dust spectral signatures from AIRS. Geophys. Res. Lett. 33, L03801. http://dx.doi.org/10.1029/2005GL024364.

DeSouza-Machado, S.G., Strow, L.L., Imbiriba, B., McCann, K., Hoff, R.M., Hannon, S.E., Martins, J.V., et al., 2010. Infrared retrievals of dust using AIRS: comparisons of optical depths and heights derived for a North African dust storm to other collocated EOS A-Train and surface observations. J. Geophys. Res. 115, D15201. http://dx.doi.org/10.1029/2009JD012842.

Deuzé, J.L., et al., 2001. Remote sensing of aerosols over land surfaces from POLDER-ADEOS-1 polarized measurements. J. Geophys. Res. 106 (D5), 4913-4926. http://dx.doi.org/10.1029/2000JD900364.

Dey, S., Di Girolamo, L., 2010. A climatology of aerosol optical and microphysical properties over the Indian subcontinent from 9 years (2000-2008) of Multiangle Imaging Spectroradiometer (MISR) data. J. Geophys. Res. 115, D15204. http://dx.doi.org/10.1029/2009JD013395.

Di Pierro, M., Jaeglé, L., Anderson, T.L., 2011. Satellite observations of aerosol transport from East Asia to the Arctic: three case studies. Atmos. Chem. Phys. 11, 2225-2243. http://dx.doi.org/10.5194/acp-11-2225-2011.

Diner, D.J., Beckert, J.C., Reilly, T.H., Bruegge, C.J., Conel, J.E., Kahn, R., Martonchik, J.V., Ackerman, T.P., Davies, R., Gerstl, S.A.W., Gordon, H.R., Muller, J.-P., Myneni, R., Sellers, J., Pinty, B., Verstraete, M.M., 1998. Multiangle Imaging Spectroadiometer (MISR) description and experiment overview. IEEE Trans. Geosci. Remote Sens. 36, 1072-1087.

Dirksen, R.J., Boersma, K.F., de Laat, J., Stamnes, P., van der Werf, G.R., Val Martin, M., Kelder, H.M., 2009. An aerosol boomerang: rapid around-theworld transport of smoke from the December 2006 Australian forest fires observed from space. J. Geophys. Res. 114, D21201. http://dx.doi.org/ 10.1029/2009JD012360.

Doherty, O.M., Riemer, N., Hameed, S., 2008. Saharan mineral dust transport into the Caribbean: observed atmospheric controls and trends. J. Geophys. Res. 113, D07211. http://dx.doi.org/10.1029/2007JD009171.

Dubovik, O., King, M.D., 2000. A flexible inversion algorithm for retrieval of aerosol optical properties from Sun and sky radiance measurements. J. Geophys. Res. 105 (D16), 20,673-20,696. http://dx.doi.org/10.1029/ 2000JD900282.

Dubovik, O., Holben, B.N., Eck, T.F., Smirnov, A., Kaufman, Y.J., King, M.D., Tanre, D., Slutsker, I., 2002. Variability of absorption and optical properties of key aerosol types observed in worldwide locations. J. Atmos. Sci. 59, 590-608.

Dubovik, O., Lapyonok, T., Kaufman, Y.J., Chin, M., Ginoux, P., Kahn, R., Sinyuk, A., 2008. Retrieving global aerosol sources from satellites using inverse modeling. Atmos. Chem. Phys. 8 (2), 209-250. http://dx.doi.org/ 10.5194/acp-8-209-2008.

Dubovik, O., Herman, M., Holdak, A., Lapyonok, T., Tanré, D., Deuzé, J.L., Ducos, F., Sinyuk, A., Lopatin, A., 2011. Statistically optimized inversion algorithm for enhanced retrieval of aerosol properties from spectral multi-angle polarimetric satellite observations. Atmos. Meas. Tech. 4, 975-1018.

Duce, R.A., et al., 1991. The atmospheric input of trace species to the world ocean. Global Biogeochem. Cycles 5 (3), 193-259.

Dulac, F., Tanre, D., Bergametti, G., Buat-Menard, P., Desbois, M., Sutton, D. 1992. Assessment of the African airborne dust mass over the western Mediterranean Sea using Meteosat data. J. Geophys. Res. 97, 2489-2506.

Edwards, D.P., et al., 2004. Observations of carbon monoxide and aerosols from the Terra satellite: Northern Hemisphere variability. J. Geophys. Res. 109, D24202, http://dx.doi.org/10.1029/2004JD004727.

Eguchi, K., Uno, I., Yumimoto, K., Takemura, T., Shimizu, A., Sugimoto, N., Liu, Z., 2009. Trans-Pacific dust transport: integrated analysis of NASA/CALIPSO and a global aerosol transport model. Atmos. Chem. Phys. 9, 3137-3145. http://dx.doi.org/10.5194/acp-9-3137-2009.

Engel-Cox, J.A., Holloman, C.H., Coutant, B.W., Hoff, R.W., 2004. Qualitative and quantitative evaluation of MODIS satellite sensor data for regional and urban air quality. Atmos. Environ. 38, 2495-2509.

Evan, A.T., Mukhopadhyay, S., 2010. African dust over the northern tropical Atlantic: 1955-2008. J. Appl. Meteorol. Climatol. 49, 2213-2229. http:// dx.doi.org/10.1175/2010JAMC2485.1.

Fan, X., Goloub, P., Deuzé, J.L., Chen, H., Zhang, W., Tanré, D., Li, Z., 2008. Evaluation of PARASOL aerosol retrieval over North East Asia. Remote Sens. Environ. 112, 697-707.

Ferrare, R.A., Fraser, R.S., Kaufman, Y.J., 1990. Satellite measurements of large-scale air pollution: measurements of forest fire smoke. J. Geophys. Res. 95, 9911-9925.

Ford, B., Heald, C.L., 2012. An A-train and model perspective on the vertical distribution of aerosols and CO in the Northern Hemisphere. J. Geophys. Res. 117, D06211. http://dx.doi.org/10.1029/2011JD016977.

Fraser, R.S., 1976. Satellite measurement of mass of Sahara dust in the atmosphere. Appl. Opt. 15, 2471-2479.

Fraser, R.S., Kaufman, Y.J., Mahoney, R.L., 1984. Satellite measurement of aerosol mass and transport. Atmos. Environ. 18, 2577-2584.

Freitas, S.R., Longo, K.M., Andreae, M.O., 2006. Impact of including the plume rise of vegetation fires in numerical simulations of associated atmospheric pollutants. Geophys. Res. Lett. 33, L17808. http://dx.doi.org/10.1029/2006GL026608. 
Gao, Y., Arimoto, R., Duce, R.A., Zhou, M.Y., Chen, C.A., Zhang, X.Y., Zhang G.Y., An, Z.S., 1997. Temporal and spatial distribution of dust and its total deposition to the China Sea. Tellus 49B, 172-189.

Gasso, S., Stein, A.F., 2007. Does dust from Patagonia reach the sub-Antarctic Atlantic Ocean? Geophys. Res. Lett. 34, L01801. http://dx.doi.org/10.1029/ 2006GL027693.

Generoso, S., Bey, I., Labonne, M., Bréon, M., 2008. Aerosol vertical distribution in dust outflow over the Atlantic: comparisons between GEOS-Chem and Cloud-Aerosol Lidar and Infrared Pathfinder Satellite Observation (CALIPSO). J. Geophys. Res. 113, D24209. http://dx.doi.org/10.1029/2008JD010154.

Giglio, L., Randerson, J.T., van der Werf, G.R., Kasibhatla, P.S., Collatz, G.J., Morton, D.C., DeFries, R.S., 2010. Assessing variability and long-term trends in burned area by merging multiple satellite fire products. Biogeosciences 7, 1171-1186. http://dx.doi.org/10.5194/bg-7-1171-2010.

Ginoux, P., Chin, M., Tegen, I., Prospero, J.M., Holben, B., Dubovik, O., Lin, S.J., 2001. Sources and distributions of dust aerosols simulated with the GOCART model. J. Geophys. Res. 106 (D17), 20,255-20,273.

Ginoux, P., Prospero, J.M., Gill, T.E., Hsu, C., Zhao, M., 2013. Global scale attribution of anthropogenic and natural dust sources and their emission rates based on MOIDS Deep Blue aerosol products. Rev. Geophys. http:// dx.doi.org/10.1029/2012RG000388.

Griffin, D.W., 2007. Atmospheric movement of microorganisms in clouds of desert dust and implications for human health. Clinical Microbiology 20, 459-477.

Grousset, F., Ginoux, P., Bory, A., Biscaye, P.E., 2003. Case study of a Chinese dust plume reaching the French Alps. Geophys. Res. Lett. 30 (6), 1277. http://dx.doi.org/10.1029/2002GL016833.

Guan, H., Esswein, R., Lopez, J., Bergstrom, R., Warnock, A., Follette-Cook, M., Fromm, M., Iraci, L.T., 2010. A multi-decadal history of biomass burning plume heights identified using aerosol index measurements. Atmos. Chem. Phys. 10, 6461-6469. http://dx.doi.org/10.5194/acp-10-6461-2010.

Gunn, R., Philips, B.B., 1957. An experimental investigation of the effect of air pollution on the initiation of rain. J. Meteorol. 14, 272-280.

Gupta, P., Christopher, S.A., Wang, J., Gehrig, R., Lee, Y.C., Kumar, N., 2006. Satellite remote sensing of particulate matter and air quality over global cities. Atmos. Environ. 40, 5880-5892.

Hadley, O.L., Corrigan, C.E., Kirchstetter, T.W., Cliff, S., Ramanathan, V., 2010. Measured black carbon deposition on the Sierra Nevada snow pack and implication for snow pack retreat. Atmos. Chem. Phys. 10, 7505-7513.

Hara, Y., Yumimoto, K., Uno, I., Shimizu, A., Sugimoto, N., Liu, Z., Winker D.M., 2009. Asian dust outflow in the PBL and free atmosphere retrieved by NASA CALIPSO and an assimilated dust transport model. Atmos. Chem. Phys. 9, 1227-1239. http://dx.doi.org/10.5194/acp-9-1227-2009.

Haywood, J.M., et al., 2008. Overview of the dust and biomass-burning experiment and African monsoon multidisciplinary analysis special observing period-0. J. Geophys. Res. 113, D00C17. http://dx.doi.org/10.1029/ 2008JD010077.

Haywood, J.M., et al., 2010. Observations of the eruption of the Sarychev volcano and simulations using the HadGEM2 climate model. J. Geophys. Res. 115, D21212. http://dx.doi.org/10.1029/2010JD014447.

Heald, C.L., et al., 2003. Asian outflow and trans-Pacific transport of carbon monoxide and ozone pollution: an integrated satellite, aircraft, and model perspective. J. Geophys. Res. 108 (D24), 4804. http://dx.doi.org/ 10.1029/2003JD003507.

Heald, C.L., et al., 2006. Transpacific transport of Asian anthropogenic aerosols and its impact on surface air quality in the United States. J. Geophys. Res. 111, D14310. http://dx.doi.org/10.1029/2005JD006847.

Heald, C.L., Ridley, D.A., Kreidenweis, S.M., Drury, E.E., 2010. Satellite observations cap the atmospheric organic aerosol budget. Geophys. Res. Lett. 37, L24808. http://dx.doi.org/10.1029/2010GL045095.

Herman, J., Bhartia, P., Torres, O., Hsu, C., Seftor, C., Celarier, E., 1997a. Global distribution of UV-absorbing aerosols from Nimbus-7/TOMS data. J. Geophys. Res. 102, 16911-16922.

Herman, M., Deuze, J.L., Marchand, A., Roger, B., Lallart, P., 1997b. Aerosol remote sensing over land surfaces including polarization measurements: applications to POLDER measurements. J. Geophys. Res. 102, 17039-17050.

Herman, M., Deuzé, J.L., Marchand, A., Roger, B., Lallart, P., 2005. Aerosol remote sensing from POLDER/ADEOS over the ocean: Improved retrieval using a nonspherical particle model. J. Geophys. Res. 110, D10S02.

Higurashi, A., Nakajima, T., 2002. Detection of aerosol types over the East China sea near Japan from four-channel satellite data. Geophys. Res. Lett. 29, 1836. http://dx.doi.org/10.1029/2002GL015357.

Hoff, R.M., Christopher, S.A., 2009. Remote sensing of particulate pollution from space: have we reached the promised land? J. Air Waste Manage. Assoc. 59, 645-675.

Holben, B.N., et al., 1998. AERONET-a federated instrument network and data archive for aerosol characterization. Remote Sens. Environ. 66 (1), 1-16.

Holloway, T., Fiore, A., Hastings, M.G., 2003. Intercontinental transport of air pollution: will emerging science lead to a new hemispheric treaty? Environ. Sci. Technol. 37, 4535-4542.
Hsu, N.C., Herman, J.R., Bhartia, P.K., Seftor, C.J., Torres, O., Thompson, A.M., Gleason, J.F., Eck, T.F., Holben, B.N., 1996. Detection of biomass burning smoke from TOMS measurements. Geophys. Res. Lett. 23, 745-748.

Hsu, N.C., Tsay, S.-C., King, M.D., Herman, J.R., 2004. Aerosol properties over bright-reflecting source regions. IEEE Trans. Geosci. Remote Sens. 42, 557-569.

Hsu, N.C., Tsay, S.-C., King, M.D., Herman, J.R., 2006. Deep blue retrievals of Asian aerosol properties during ACE-Asia. IEEE Trans. Geosci. Remote Sens. 44, 3180-3195. http://dx.doi.org/10.1029/2005JD006549.

Hsu, N.C., Li, C., Krotkov, N.A., Liang, Q., Yang, K., Tsay, S.-C., 2012. Rapid transpacific transport in autumn observed by the A-Train satellites. J. Geophys. Res. 117, D06312. http://dx.doi.org/10.1029/2011JD016626.

Hsu, S.-C., et al., 2009. Dust deposition to the East China Sea and its biogeochemical implications. J. Geophys. Res. 114, D15304. http:// dx.doi.org/10.1029/2008JD011223.

HTAP, 2010. Hemispheric transport of air pollution 2010 - part A: ozone and particulate matter. In: Dentener, Frank, Keating, Terry, Akimoto, Hajime (Eds.), Air Pollution Studies, 17. United Nations, New York and Geneva.

Hu, Y., Vaughan, M., Liu, Z., Powell, K., Rodier, S., 2007. Retrieving optical depths and lidar ratios for transparent layers above opaque water clouds from CALIPSO lidar measurements. IEEE Geosci. Remote Sens. Lett. 4 (4), 523-526.

Huang, J., Minnis, P., Chen, B., Huang, Z., Liu, Z., Zhao, Q., Yi, Y., Ayers, J.K., 2008. Long-range transport and vertical structure of Asian dust from CALIPSO and surface measurements during PACDEX. J. Geophys. Res. 113, D23212. http://dx.doi.org/10.1029/2008JD010620.

Huang, J., Zhang, C., Prospero, J.M., 2010. African dust outbreaks: a satellite perspective of temporal and spatial variability over the tropical Atlantic Ocean. J. Geophys. Res. 115, D05202. http://dx.doi.org/10.1029/ 2009JD012516.

Huebert, B.J., Bates, T., Russell, P.B., Shi, G., Kim, Y.J., Kawamura, K., Carmichael, G., Nakajima, 2003. An overview of ACE-Asia: strategies for quantifying the relationships between Asian aerosols and their climatic impacts. J. Geophys. Res. 108, 8633. http://dx.doi.org/10.1029/2003JD003550.

Huneeus, N., Chevallier, F., Boucher, O., 2012. Estimating aerosol emissions by assimilating observed aerosol optical depth in a global aerosol model. Atmos. Chem. Phys. 12, 4585-4606.

Husar, R.B., et al., 2001. The Asian dust events of April, 1998. J. Geophys. Res. $106,18317-18330$

Hyer, E.J., Reid, J.S., Zhang, J., 2011. An over-land aerosol optical depth data set for data assimilation by filtering, correction, and aggregation of MODIS Collection 5 optical depth retrievals. Atmos. Meas. Tech. 4, 379-408. http://dx.doi.org/10.5194/amt-4-379-2011.

Ichoku, C., Chu, D.A., Mattoo, S., Kaufman, Y.J., Remer, L.A., Tanre, D., Slutsker, I., Holben, B.N., 2002. A spatio-temporal approach for global validation and analysis of MODIS aerosol products. Geophys. Res. Lett. 29. http:// dx.doi.org/10.1029/2001GL013206.

Ichoku, C., Giglio, L., Wooster, M.J., Remer, L.A., 2008. Global characterization of biomass-burning patterns using satellite measurements of fire radiative energy. Remote Sens. Environ. 112, 2950-2962. http://dx.doi.org/10.1016/ j.rse.2008.02.009.

Ichoku, C., Kahn, R.A., Chin, M., 2012. Satellite contributions to the quantitative characterization of biomass burning for climate modeling. Atmos. Res 111, 1-28. http://dx.doi.org/10.1016/j.atmosres.2012.03.007.

Itahashi, S., Yumimoto, K., Uno, I., Eguchi, K., Takemura, T., Hara, Y., Shimizu, A., Sugimoto, N., Liu, Z., 2010. Structure of dust and air pollutant outflow over East Asia in the spring. Geophys. Res. Lett. 37, L20806. http:// dx.doi.org/10.1029/2010GL044776.

Jacob, D.J., Crawford, J.H., Kleb, M.M., Connors, V.S., Bendura, R.J., Raper, J.R., Sachse, G.M., Gille, J.C., Emmons, C.L. Heald, 2003. Transport and Chemical Evolution over the Pacific (TRACE-P) aircraft mission: design, execution, and first results. J. Geophys. Res. 108, 9000. http://dx.doi.org/ 10.1029/2002JD003276.

Jacob, D.J., et al., 2010. The Arctic Research of the Composition of the Troposphere from Aircraft and Satellites (ARCTAS) mission: design, execution, and first results. Atmos. Chem. Phys. 10, 5191-5212.

Jaffe, D., et al., 1999. Transport of Asian air pollution to North America. Geophys. Res. Lett. 26, 711-714.

Jeong, M.-J., Hsu, N.C., 2008. Retrievals of aerosol single-scattering albedo and effective aerosol layer height for biomass-burning smoke: synergy derived from "A-Train" sensors. Geophys. Res. Lett. L24801, 35. http:// dx.doi.org/10.1029/2008GL036279.

Jeong, M.-J., Li, Z., Chu, D.A., Tsay, S.-C., 2005. Quality and compatibility analyses of global aerosol products derived from the advanced very high resolution radiometer and Moderate Resolution Imaging Spectroradiometer. J. Geophys. Res. 110, D10S09. http://dx.doi.org/10.1029/2004JD004648.

Jethva, H., Torres, O., Remer, L.A., Bhartia, P.K., 2013. A color ratio method for simultaneous retrieval of aerosol and cloud optical thickness of above cloud absorbing aerosols from passive sensors: Applications to MODIS measurements. IEEE Trans. Geosci. Remote Sens. in press. 
Jickells, T.D., et al., 2005. Global iron connections between desert dust, ocean biogeochemistry and climate. Science 308, 67-71.

Kahn, R.A., 2012. Reducing the uncertainties in direct aerosol radiative forcing. Surv. Geophys. http://dx.doi.org/10.1007/s10712-011-9153-z.

Kahn, R.A., Banerjee, P., McDonald, D., Diner, D., 1998. Sensitivity of multiangle imaging to aerosol optical depth, and to pure-particle size distribution and composition over ocean. J. Geophys. Res. 195-32 (213), 103, 32.

Kahn, R.A., Banerjee, P., McDonald, D., 2001. The sensitivity of multiangle imaging to natural mixtures of aerosols over ocean. J. Geophys. Res. 106, 18219-18238.

Kahn, R.A., Gaitley, B., Martonchik, J., Diner, D., Crean, K., Holben, B.N., 2005. MISR global aerosol optical depth validation based on two years of coincident AERONET observations. J. Geophys. Res. 110. http://dx.doi.org/ 10.1029/2004JD004706.

Kahn, R.A., Li, W.-H., Moroney, C., Diner, D.J., Martonchik, J.V., Fishbein, E., 2007. Aerosol source plume physical characteristics from space-based multiangle imaging. J. Geophys. Res. 112, D11205. http://dx.doi.org/ 10.1029/2006JD007647.

Kahn, R.A., Chen, Y., Nelson, D., Leung, F.-Y., Li, Q., Diner, D., Logan, J., 2008. Wildfire smoke injection heights - two perspectives from space. Geophys. Res. Lett. 35, 4. http://dx.doi.org/10.1029/2007GL032165.

Kahn, R.A., Nelson, D.L., Garay, M., Levy, R.C., Bull, M.C., Martonchik, J.V., Diner, D.J., Paradise, S.R., Wu, D., Hansen, E.G., Remer, L.A., 2009. MISR aerosol product attributes, and statistical comparisons with MODIS. IEEE Trans. Geosci. Remote Sens. 47 (12), 4095-4114. http://dx.doi.org/ 10.1109/TGRS.2009.2023115

Kahn, R.A., Gaitley, B.J., Garay, M.J., Diner, D.J., Eck, T., Smirnov, A., Holben, B.N., 2010. Multiangle Imaging SpectroRadiometer global aerosol product assessment by comparison with the Aerosol Robotic Network. J. Geophys. Res. 115, D23209. http://dx.doi.org/10.1029/2010JD014601.

Kalashnikova, O.V., Kahn, R.A., 2006. Ability of multiangle remote sensing observations to identify and distinguish mineral dust types: part 2 . Sensitivity over dark water. J. Geophys. Res. 111, D11207. http:// dx.doi.org/10.1029/2005JD006756.

Kalashnikova, O.V., Kahn, R.A., 2008. Mineral dust plume evolution over the Atlantic from combined MISR/MODIS aerosol retrievals. J. Geophys. Res. 113, D24204. http://dx.doi.org/10.1029/2008JD010083.

Kaufman, Y.J., Tanré, D., Remer, L.A., Vermote, E., Chu, A., Holben, B.N., 1997. Operational remote sensing of tropospheric aerosol over land from EOS Moderate Resolution Imaging Spectroradiometer. J. Geophys. Res. 102, 17051-17067.

Kaufman, Y.J., Remer, L.A., Tanré, D., et al., 2005a. A critical examination of the residual cloud contamination and diurnal sampling effects on MODIS estimates of aerosol over ocean. IEEE Trans. Geosci. Remote Sens. 43 (12), 2886-2897.

Kaufman, Y.J., Boucher, O., Tanré, D., Chin, M., Remer, L.A., Takemura, T., 2005b. Aerosol anthropogenic component estimated from satellite data. Geophys. Res. Lett. 32, L17804. http://dx.doi.org/10/1029/2005GL023125.

Kaufman, Y.J., Koren, I., Remer, L.A., Rosenfeld, D., Rudich, Y., 2005c. The effect of smoke, dust and pollution aerosol on shallow cloud development over the Atlantic Ocean. Proc. Natl. Acad. Sci. 102 (32), 11207-11212.

Kaufman, Y.J., Koren, I., Remer, L.A., Tanré, D., Ginoux, P., Fan, S., 2005d. Dust transport and deposition observed from the Terra-Moderate Resolution Imaging Spectroradiometer (MODIS) spacecraft over the Atlantic Ocean. J. Geophys. Res. 110, D10S12. http://dx.doi.org/10.1029/2003JD004436.

Kim, D., Chin, M., Bian, H., Tan, Q., Brown, M.E., Zheng, T., You, R., Diehl, T., Ginoux, P., Kucsera, T., 2013. The effect of the dynamic surface bareness to dust source function, emission, and distribution. J. Geophys. Res. 118. http:// dx.doi.org/10.1029/2012JD017907.

Kinne, S., et al., 2006. An AeroCom initial assessment - optical properties in aerosol component modules of global models. Atmos. Chem. Phys. 6, 1815-1834. http://dx.doi.org/10.5194/acp-6-1815-2006.

Knapp, K.R., Vonder Haar, T.H., Kaufman, Y.J., 2002. Aerosol optical depth retrieval from GOES-8: uncertainty study and retrieval validation over South America. J. Geophys. Res. 107 (D7), 4055. http://dx.doi.org/10.1029/2001JD000505.

Koch, D., Schulz, M., Kinne, S., McNaughton, C., Spackman, J.R., Bond, T.C., Balkanski, Y., et al., 2009. Evaluation of black carbon estimations in global aerosol models. Atmos. Chem. Phys. 9, 9001-9026.

Koffi, B., et al., 2012. Application of the CALIOP layer product to evaluate the vertical distribution of aerosols estimated by global models: AeroCom phase I results. J. Geophys. Res. 117, D10201. http://dx.doi.org/10.1029/ 2011JD016858.

Koren, I., Kaufman, Y.J., 2004. Direct wind measurements of Saharan dust events from Terra and Aqua satellites. Geophys. Res. Lett. 31, L06122. http://dx.doi.org/10.1029/2003GL019338.

Koren, I., Kaufman, Y.J., Rosenfeld, D., Remer, L.A., Rudich, Y., 2005. Aerosol invigoration and restructuring of Atlantic convective clouds. Geophys. Res. Lett. 32, LI4828. http://dx.doi.org/10.1029/2005GL0231872005.

Koren, I., Kaufman, Y.J., Washington, R., Todd, M.C., Rudich, Y., Martins, J.V., Rosenfeld, D., 2006. The Bodélé depression: a single spot in the Sahara that provides most of the mineral dust to the Amazon forest. Environ. Res. Lett. 1, 014005. http://dx.doi.org/10.1088/1748-9326/1/1/014005.

Koven, C.D., Fung, I., 2008. Identifying global dust source areas using highresolution land surface form. J. Geophys. Res. 113, D22204. http:// dx.doi.org/10.1029/2008JD010195.

Laszlo, I., Ciren, P., Liu, H., Kondragunta, S., Tarpley, T.D., Goldberg, M.D., 2008. Remote sensing of aerosol and radiation from geostationary satellites. Adv. Space Res. 41 (11), 1882-1893. http://dx.doi.org/ 10.1016/j.asr.2007.06.047.

Lau, K.-M., Kim, K.-M., 2006. Observational relationships between aerosol and Asian monsoon rainfall, and circulation. Geophys. Res. Lett. 33, L21810. http://dx.doi.org/10.1029/2006GL027546.

Lau, K.M., Kim, K.M., Sud, Y.C., Walker, G.K., 2009. A GCM study of the response of the atmospheric water cycle of West Africa and the Atlantic to Saharan dust radiative forcing. Ann. Geophys. 27, 4023-4037.

Leibensperger, E.M., Mickley, L.J., Jacob, D.J., Chen, W.-T., Seinfeld, J.H., Nenes, A., Adams, P.J., Streets, D.G., Kumar, N., Rind, D., 2012. Climatic effects of 1950-2050 changes in US anthropogenic aerosols - part 1: aerosol trends and radiative forcing. Atmos. Chem. Phys. 12, 3333-3348. http:// dx.doi.org/10.5194/acp-12-3333-2012.

Levy, R., Leptoukh, G., Kahn, R., Zubko, V., Gopalan, A., Remer, L., 2009. A critical look at deriving monthly aerosol optical depth from satellite data. IEEE Trans. Geosci. Remote Sens. 9 (47(8)), 2942-2956.

Levy, R., Remer, L.A., Kleidman, R.G., Mattoo, S., Ichoku, C., Kahn, R., Eck, T.F., 2010. Global evaluation of the Collection 5 MODIS dark-target aerosol products over land. Atmos. Chem. Phys. 10, 10399-10420. http://dx.doi.org/ 10.5194/acp-10-10399-2010.

Li, Z., et al., 2007. Preface to special section on East Asian Studies of Tropospheric Aerosols: An International Regional Experiment (EAST-AIRE). J. Geophys. Res. 112, D22S00. http://dx.doi.org/10.1029/2007JD008853.

Li, F., Ginoux, P., Ramaswamy, V., 2010. Transport of Patagonian dust to Antarctica. J. Geophys. Res. 115, D18217. http://dx.doi.org/10.1029/2009JD012356.

Liu, Z., Sugimoto, N., Murayama, T., 2002. Extinction-to-backscatter ratio of Asian dust observed with high-spectral-resolution lidar and Raman lidar. Appl. Opt. 41, 2760-2767. http://dx.doi.org/10.1364/A0.41.002760.

Liu, H., Pinker, R.T., Holben, B.N., 2005a. A global view of aerosols from merged transport models, satellite, and ground observations. J. Geophys. Res. 110, D10S15. http://dx.doi.org/10.1029/2004JD004695.

Liu, Y., Sarnat, J.A., Kilaru, V., Jacob, D.J., Koutrakis, P., 2005b. Estimating ground level $\mathrm{PM}_{2.5}$ in the Eastern United States using satellite remote sensing. J. Environ. Sci. Technol. 39 (9), 3269-3278.

Liu, Y., Kahn, R., Koutrakis, P., 2007. Estimating PM2.5 component concentrations and size distributions using satellite retrieved fractional aerosol optical depth: part I - method development. J. Air Waste Manage. Assoc. 57 (11), 1351-1359.

Liu, D., Wang, Z., Liu, Z., Winker, D., Trepte, C., 2008a. A height resolved global view of dust aerosols from the first year CALIPSO lidar measurements. J. Geophys. Res. 113, D16214. http://dx.doi.org/10.1029/2007JD009776.

Liu, Z., et al., 2008b. CALIPSO lidar observations of the optical properties of Saharan dust: a case study of long-range transport. J. Geophys. Res. 113, D07207. http://dx.doi.org/10.1029/2007JD008878, 2008.

Luo, C., Mahowald, N., del Corral, J., 2003. Sensitivity study of meteorological parameters on mineral aerosol mobilization, transport and distribution. J. Geophys. Res. 108 (D15), 4447. http://dx.doi.org/10.1029/2003JD003483.

Lyapustin, A., Wang, Y., Laszlo, I., Kahn, R., Korkin, S., Remer, L., Levy, R., Reid, J., 2011. Multi-angle implementation of atmospheric correction (MAIAC): part 2. Aerosol algorithm. J. Geophys. Res. 116 (D03211). http://dx.doi.org/ 10.1029/2010JD014986.

Lyons, W.A., Dooley Jr., J.C., Whitby, K.T., 1978. Satellite detection of longrange pollution transport and sulfate aerosol hazes. Atmos. Environ. 12, 621-631

Mahowald, N.M., Baker, A.R., Bergametti, G., Brooks, N., Duce, R.A., Jickells, T.D. Kubilay, N., Prospero, J.M., Tegen, I., 2005. Atmospheric global dust cycle and iron inputs to the ocean. Global Biogeochem. Cycles 19, GB4025. http://dx.doi.org/10.1029/2004GB002402

Malm, W.C., Schichtel, B.A., Pitchford, M.L., Ashbaugh, A.A., Eldred, R.A., 2004. Spatial and monthly trends in speciated fine particle concentration in the United States. J. Geophys. Res. 109, D03306. http://dx.doi.org/10.1029/ 2003JD003739.

Martin, R.V., 2008. Satellite remote sensing of surface air quality. Atmos. Environ. 42, 7823-7843.

Martins, J.V., Tanre, D., Remer, L.A., Kaufman, Y.J., Mattoo, S., Levy, R., 2002. MODIS cloud screening for remote sensing of aerosol over oceans using spatial variability. Geophys. Res. Lett. 29. http://dx.doi.org/10.1029/2001GL01352.

Martonchik, J.V., Diner, D.J., Kahn, R., Verstraete, M.M., Pinty, B., Gordon, H.R., Ackerman, T.P., 1998. Techniques for the retrieval of aerosol properties over land and ocean using multiangle data. IEEE Trans. Geosci. Remote Sens. 36, 1212-1227.

Martonchik, J.V., Diner, D.J., Crean, K., Bull, M., 2002. Regional aerosol retrieval results from MISR. IEEE Trans. Geosci. Remote Sens. 40, 1520-1531. 
Martonchik, J.V., Kahn, R.A., Diner, D.J., 2009. Retrieval of aerosol properties over land using MISR observations. In: Kokhanovsky, A.A., de Leeuw, G. (Eds.), Satellite Aerosol Remote Sensing Over Land. Springer, Berlin, pp. 267-293.

Matsui, T., Kreidenweis, S., Pielke Sr., R.A., Schichtel, B., Yu, H., Chin, M., Chu, A., Niyogi, D., 2004. Regional comparison and assimilation of GOCART and MODIS aerosol optical depth across the eastern U.S. Geophys. Res. Lett. 31, L21101. http://dx.doi.org/10.1029/2004GL021017.

Mattis, I., Ansmann, A., Muller, D., Wandinger, U., Althausen, D., 2002. Dualwavelength Raman lidar observations of the extinction-to-backscatter ratio of Saharan dust. Geophys. Res. Lett. 29, 1306. http://dx.doi.org/ 10.1029/2002GL014721.

McCormick, R.A., Ludwig, J.H., 1967. Climate modification by atmospheric aerosols. Science 156, 1358-1359.

McNeil, W., Carswell, A., 1975. Lidar polarization studies of the troposphere. Appl. Opt. 14, 2158-2168

Mekler, Y., Quenzel, H., Ohring, G., Marcus, I., 1977. Relative atmospheric aerosol content from ERTS observations. J. Geophys. Res. 82, 967-970.

Mishchenko, M.I., Cairns, B., Chowdhary, J., Geogdzhayev, I.V., Liu, L., Travis, L.D. 2005. Remote sensing of terrestrial tropospheric aerosols from aircraft and satellites. J. Phys. Conf. Ser. 6, 73-89. http://dx.doi.org/10.1088/1742-6596/ $6 / 1 / 005$.

Moulin, C., Lambert, C., Dulac, F., Dayan, U., 1997. Control of atmospheric export of dust from North Africa by the North Atlantic Oscillation. Nature 387, 691-694.

Murayama, T., et al., 2001. Ground-based network observation of Asian dust events of April 1998 in east Asia. J. Geophys. Res. 106, 18345-18360.

Nowottnick, E., Colarco, P., da Silva, A., Hlavka, D., McGill, M., 2011. The fate of Saharan dust across the Atlantic and implications for a central American dust barrier. Atmos. Chem. Phys. 11, 8415-8431.

Pelletier, B., Santer, R., Vidot, J., 2007. Retrieving of particulate matter from optical measurements: a semiparametric approach. J. Geophys. Res. 112, D06208. http://dx.doi.org/10.1029/2005JD006737.

Pereira, G., Freitas, S.R., Moraes, E.C., Ferreira, N.J., Shimabukuro, Y.E., Rao, V.B., Longo, K.M., 2009. Estimating trace gas and aerosol emissions over South America: relationship between fire radiative energy released and aerosol optical depth observations. Atmos. Environ. 43, 6388-6397.

Petrenko, M., Kahn, R.A., Chin, M., Soja, A., Kucsera, T., Harshvardhan, 2012. The use of satellite-measured aerosol optical depth to constrain biomass burning emissions source strength in a global aerosol model (GOCART) J. Geophys. Res. 117, D18212. http://dx.doi.org/10.1029/2012JD017870.

Peyridieu, S., Chedin, A., Tanre, D., Capelle, V., Pierangelo, C., Lamquin, N. Armante, R., 2010. Saharan dust infrared optical depth and altitude retrieved from AIRS: a focus over North Atlantic - comparisons to MODIS and CALIPSO. Atmos. Chem. Phys. 10, 1953-1967.

Pierangelo, C., Chédin, A., Heilliette, S., Jacquinet-Husson, N., Armante, R., 2004. Dust altitude and infrared optical depth from AIRS. Atmos. Chem. Phys. 4, 1813-1822.

Pope III, C.A., Burnett, R.T., Thun, M.J., Calle, E.E., Krewski, D., Ito, K., et al., 2002. Lung cancer, cardiopulmonary mortality, and long-term exposure to fine particulate air pollution. J. Am. Med. Assoc. 287, 1132-1141.

Prados, A.I., Kondragunta, S., Ciren, P., Knapp, K.R., 2007. GOES Aerosol/ Smoke Product (GASP) over North America: comparisons to AERONET and MODIS observations. J. Geophys. Res. 112, D15201. http:// dx.doi.org/10.1029/2006JD007968.

Propsero, J.M., Savoie, D.L., Arimoto, R., 2003. Long-term record of NSS-sulfate and nitrate in aerosols on Midway Island, 1981-2000: evidence of increased (no decreasing?) anthropogenic emissions from Asia. J. Geophys. Res. 108 4019. http://dx.doi.org/10.1029/2001JD001524.

Prospero, J.M., 1996. The atmospheric transport of particles to the ocean. In Ittekkot, V., et al. (Ed.), Particle Flux in the Ocean. John Wiley, Hoboken, N. J., pp. 19-52.

Prospero, J.M., 1999. Long-range transport of mineral dust in the global atmosphere: impact of African dust on the environment of the southeastern United States. Proc. Natl. Acad. Sci. U. S. A. 96, 3396-3403.

Prospero, J.M., Carlson, T.N., 1972. Vertical and areal distribution of Saharan dust over the western equatorial North Atlantic Ocean. J. Geophys. Res. 77 (27), 5255-5265. http://dx.doi.org/10.1029/JC077i027p05255.

Prospero, J.M., Ginoux, P., Torres, O., Nicholson, S.E., Gill, T.E., 2002. Environmental characterization of global sources of atmospheric soil dust identified with the NIMBUS 7 Total Ozone Mapping Spectrometer (TOMS) absorbing aerosol product. Rev. Geophys. 40 (1), 1002. http:// dx.doi.org/10.1029/2000RG000095.

Prospero, J.M., Blades, E., Mathison, G., Naidu, R., 2005. Interhemispheric transport of viable fungi and bacteria from Africa to the Caribbean with soil dust. Aerobiologia 21 (1), 119. http://dx.doi.org/10.1007/s10453-004-5872-7.

Prospero, J.M., Landing, W.M., Schulz, M., 2010. African dust deposition to Florida: temporal and spatial variability and comparisons to models. J. Geophys. Res. 115, D13304. http://dx.doi.org/10.1029/2009JD012773.

Rahn, K.A., Borys, R., Shaw, G.E., 1977. The Asian source of Arctic haze bands. Nature 268, 713-715
Ramanathan, V., Carmichael, G., 2008. Global and regional climate changes due to black carbon. Nat. Geosci. 1, 221-227.

Ramanathan, V., Chung, C., Kim, D., Bettge, D., Buja, L., Kiehl, J.T., Washington, W.M., Fu, Q., Sikka, D.R., Wild, M., 2005. Atmospheric brown clouds: impacts on South Asian climate and hydrological cycle. Proc. Natl. Acad. Sci. 102, 5326-5333.

Rasch, P.J., Collins, W.D., Eaton, B.E., 2001. Understanding the Indian Ocean Experiment (INDOEX) aerosol distributions with an aerosol assimilation. J. Geophys. Res. 106 (D7), 7337-7355. http://dx.doi.org/10.1029/ 2000JD900508.

Reid, J.S., et al., 2003. Analysis of measurements of Saharan dust by airborne and ground-based remote sensing methods during the Puerto Rico Dust Experiment (PRIDE). J. Geophys. Res. 108, 8586. http://dx.doi.org/10.1029/ 2002JD002493.

Reid, J.S., Prins, E.M., Westphal, D.L., Schmidt, C.C., Richardson, K.A., Christopher, S.A., Eck, T.F., Reid, E.A., Curtis, C.A., Hoffman, J.P., 2004. Real-time monitoring of South American smoke particle emissions and transport using a coupled remote sensing/box-model approach. Geophys. Res. Lett. 31, L06107. http://dx.doi.org/10.1029/2003GL018845.

Reid, J.S., Hyer, E.J., Prins, E.M., Westphal, D.L., Zhang, J., Wang, J., Christopher, S.A., Curtis, C.A., Schmidt, C.C., Eleuterio, D.P., Richardson, K.A., Hoffman, J.P., 2009. Global monitoring and forecasting of biomass-burning smoke: description of and lessons from the Fire Locating and Modeling of Burning Emissions (FLAMBE) program. IEEE J. Sel. Topics Appl. Earth Observ. Remote Sens. (JSTARS-2009-00034).

Remer, L.A., Tanré, D., Kaufman, Y.J., et al., 2002. Validation of MODIS aerosol retrieval over ocean. Geophys. Res. Lett. 29. http://dx.doi.org/10.1029/ $2001 \mathrm{GL} 013204$.

Remer, L.A., Kaufman, Y.J., Tanré, D., et al., 2005. The MODIS aerosol algorithm, products, and validation. J. Atmos. Sci. 62, 947-973.

Remer, L.A., Kleidman, R.G., Levy, R.C., Kaufman, Y.J., Tanre, D., Mattoo, S., Martins, J.V., Ichoku, C., Koren, I., Yu, H.B., Holben, B.N., 2008. Global aerosol climatology from the MODIS satellite sensors. J. Geophys. Res. 113, D14S07. http://dx.doi.org/10.1029/2007JD009661.

Ridley, D.A., Heald, C.L., Ford, B., 2012. North African dust export and deposition: a satellite and model perspective. J. Geophys. Res. 117, D02202. http:// dx.doi.org/10.1029/2011JD016794.

Rudich, Y., Kaufman, Y.J., Dayan, U., Yu, H., Kleidman, R.G., 2008. Estimation of transboundary transport of pollution aerosols by remote sensing in the eastern Mediterranean. J. Geophys. Res. 113, D14S13. http://dx.doi.org/ 10.1029/2007JD009601.

Russell, P.B., Hobbs, P.V., Stowe, L.L., 1999. Aerosol properties and radiative effects in the United States East Coast haze plume: an overview of the Tropospheric Aerosol Radiative Forcing Observational Experiment (TARFOX). J. Geophys. Res. 104 (D2), 2213-2222. http://dx.doi.org/10.1029/1998JD200028.

Russell, P.B., Bergstrom, R.W., Shinozuka, Y., Clarke, A.D., DeCarlo, P.F., Jimenez, J.L., Livingston, J.M., Redemann, J., Dubovik, O., Strawa, A., 2010. Absorption Angstrom Exponent in AERONET and related data as an indicator of aerosol composition. Atmos. Chem. Phys. 10, 1155-1169. http://dx.doi.org/10.5194/acp-10-1155-2010.

Sassen, K., 2002. Indirect climate forcing over the western US from Asian dust storms. Geophys. Res. Lett. 29, 1465.

Satheesh, S.K., Torres, O., Remer, L.A., Babu, S.S., Vinoj, V., Eck, T.F., Kleidman, R.G., Holben, B.N., 2009. Improved assessment of aerosol absorption using OMIMODIS joint retrieval. J. Geophys. Res. 114, D05209. http://dx.doi.org/ 10.1029/2008JD011024.

Schepanski, K. Tegen, I. Laurent, B., Heinold, B., Macke, A, 2007. A new Saharan dust source activation frequency map derived from MSG-SEVIRI IR-channels. Geophys. Res. Lett. 34, L18803. http://dx.doi.org/10.1029/2007GL030168.

Schepanski, K., Tegen, I., Macke, A., 2009. Saharan dust transport and deposition towards the tropical northern Atlantic. Atmos. Chem. Phys. 9, 1173-1189. http://dx.doi.org/10.5194/acp-9-1173-2009.

Schulz, M., Textor, C., Kinne, S., Balkanski, Y., Bauer, S., Berntsen, T., Berglen, T., et al., 2006. Radiative forcing by aerosols as derived from the AeroCom present-day and pre-industrial simulations. Atmos. Chem. Phys. 6, 5225-5246.

Scollo, S., Folch, A., Coltelli, M., Realmuto, V.J., 2010. Three-dimensional volcanic aerosol dispersal: a comparison between Multiangle Imaging Spectroradiometer (MISR) data and numerical simulations. J. Geophys. Res. 115, D24210. http://dx.doi.org/10.1029/2009JD013162.

Sessions, W.R., Fuelberg, H.E., Kahn, R.A., Winker, D.M., 2011. An investigation of methods for injecting emissions from boreal wildfires using WRF-Chem during ARCTAS. Atmos. Chem. Phys. 11, 5719-5744. http://dx.doi.org/ 10.5194/acp-11-5719-2011.

Shaw, G.E., 1983. Evidence for a central Eurasian source area of Arctic haze in Alaska. Nature 299, 815-818.

Shi, Y., Zhang, J., Reid, J.S., Holben, B., Hyer, E.J., Curtis, C., 2011. An analysis of the collection 5 MODIS over-ocean aerosol optical depth product for its implication in aerosol assimilation. Atmos. Chem. Phys. 11, 557-565. http://dx.doi.org/10.5194/acp-11-557-2011. 
Shindell, D., Chin, M., Dentener, F., Doherty, R.M., Faluvegi, G., Fiore, A.M., Hess, P., et al., 2008. A multi-model assessment of pollution transport to the Arctic. Atmos. Chem. Phys. 8, 5353-5372.

Singh, H.B., Brune, W.H., Crawford, J.H., Flocke, F., Jacob, D.J., 2009. Chemistry and transport of pollution over the Gulf of Mexico and the Pacific: spring 2006 INTEX-B campaign overview and first results. Atmos. Chem. Phys. 9, 2301-2318.

Sirocko, F., Sarnthein, M., 1989. Wind-borne deposits in the Northwestern Indian Ocean: record of Holocene sediments versus modern satellite data. In: Leinen, M., Sarnthein, M. (Eds.), Paleoclimatology and Paleometeorology. NATO ASI Series, C, Math. and Phys. Sciences, Vol. 282. Kluwer Academic Publishers, Dordrecht, Boston, London, pp. 401-433.

Smirnov, A., et al., 2009. Maritime Aerosol Network as a component of Aerosol Robotic Network. J. Geophys. Res. 114, D06204. http://dx.doi.org/10.1029/ 2008JD011257.

Smith, D.J., Jaffe, D.J., Birmele, M.N., Griffin, D.W., Schuerger, A.C., Hee, J., Roberts, M.S., 2012. Free tropospheric transport of microorganisms from Asia to North America. Microb. Ecol. 64, 973-985.

Stephens, G.L., Vane, D.G., Boain, R.J., Mace, G.G., Sassen, K., Wang, Z., Illingworth, A.J., 2002. The CloudSat mission and the A-Train: a new dimension o space-based observation of clouds and precipitation. Bull. Am. Meteorol. Soc. 83, 1771-1790.

Stohl, A., Forster, C., Huntrieser, H., et al., 2007. Aircraft measurements over Europe of an air pollution plume from Southeast Asia - aerosol and chemical characterization. Atmos. Chem. Phys. 7, 913-937.

Su, L., Toon, O.B., 2011. Saharan and Asian dust: similarities and differences determined by CALIPSO, AERONET, and a coupled climate-aerosol microphysical model. Atmos. Chem. Phys. 11, 3263-3280. http:// dx.doi.org/10.5194/acp-11-3263-2011.

Swap, R., Garstang, M., Greco, S., Talbot, R., Kallberg, P., 1992. Saharan dust in the Amazon Basin. Tellus 44B, 133-149.

Tanré, D., Bréon, F.M., Deuzé, J.L., Herman, M., Goloub, P., Nadal, F., Marchand, A., 2001. Global observation of anthropogenic aerosols from satellite. Geophys. Res. Lett. 28 (24), 4555-4558.

Tanré, D., Haywood, J.M., Pelon, J., Léon, J.F., Chatenet, B., Formenti, P., Francis, P., Goloub, P., Highwood, E.J., Myhre, G., 2003. Measurement and modeling of the Saharan dust radiative impact: overview of the Saharan Dust Experiment (SHADE). J. Geophys. Res. 108, 8574. http://dx.doi.org/ 10.1029/2002JD003273.

Tanré, D., Bréon, F.M., Deuzé, J.L., Dubovik, O., Ducos, F., François, P., Goloub, P., Herman, M., Lifermann, A., Waquet, F., 2011. Remote sensing of aerosols by using polarized, directional and spectral measurements within the A-Train: the PARASOL mission. Atmos. Meas. Tech. 4, 1383-1395. http://dx.doi.org/10.5194/amt-4-1383-2011.

Tegen, I., Hollrig, P., Chin, M., Fung, I., Jacob, D., Penner, J., 1997. Contribution of different aerosol species to the global aerosol extinction optical thickness: estimates from model results. J. Geophys. Res. 102 (D20), 23,895-23,915. http://dx.doi.org/10.1029/97JD01864.

Tegen, I., Werner, M., Harrison, S.P., Kohfeld, K.E., 2004. Relative importance of climate and land use in determining present and future global soil dust emission. Geophys. Res. Lett. 31, L05105. http://dx.doi.org/10.1029/ 2003GL019216.

Textor, C., Schulz, M., Guibert, S., Kinne, S., Balkanski, Y., Bauer, S., Berntsen, T., et al., 2006. Analysis and quantification of the diversities of aerosol life cycles within AeroCom. Atmos. Chem. Phys. 6, 1777-1813.

Textor, C., et al., 2007. The effect of harmonized emissions on aerosol properties in global models - an AeroCom experiment. Atmos. Chem. Phys. 7, 4489-4501. http://dx.doi.org/10.5194/acp-7-4489-2007.

Thieuleux, F., Moulin, C., Breon, F.M., Maignan, F., Poitou, J., Tanre, D., 2005. Remote sensing of aerosols over the oceans using MSG/SEVIRI imagery. Ann. Geophys. 23, 1-8.

Tian, B., Waliser, D.E., Kahn, R.A., Li, O., Yung, Y.L., Tyranowski, T., Geogdzhayev, I.V., Mishchenko, M.I., Torres, O., Smirnov, A., 2008. Does the Madden-Julian Oscillation influence aerosol variability? J. Geophys. Res. 113, D12215. http://dx.doi.org/10.1029/2007JD009372.

Tian, B., Waliser, D.E., Kahn, R.A., Wong, S., 2011. Modulation of Atlantic aerosols by the Madden-Julian Oscillation. J. Geophys. Res. 116, D15108. http://dx.doi.org/10.1029/2010JD015201.

Torres, O., Jethva, H., Bhartia, P.K., 2012. Retrieval of aerosol optical depth over clouds from OMI observations: sensitivity analysis and case studies. J. Atmos. Sci. 69, 1037-1053. http://dx.doi.org/10.1175/JAS-D-110130.1 .

Twomey, S., 1977. The influence of pollution on the shortwave albedo of clouds. J. Atmos. Sci. 34, 1149-1152.

Uematsu, M., Duce, R.A., Prospero, J.M., 1985. Deposition of atmospheric mineral particles in the North Pacific Ocean. J. Atmos. Chem. 3, 123-138.

Uematsu, M., Wang, Z.F., Uno, I., 2003. Atmospheric input of mineral dust to the western North Pacific region based on direct measurements and a regional chemical transport model. Geophys. Res. Lett. 30 (6), 1342. http://dx.doi.org/10.1029/2002GL016645.
Uno, I., Yumimoto, K., Shimizu, A., Hara, Y., Sugimoto, N., Wang, Z., Liu, Z. Winker, D.M., 2008. 3D structure of Asian dust transport revealed by CALIPSO lidar and a 4DVAR dust model. Geophys. Res. Lett. 35, L06803. http://dx.doi.org/10.1029/2007GL032329.

Uno, I., Eguchi, K., Yumimoto, K., Takemura, T., Shimizu, A., Uematsu, M., Liu, Z., Wang, Z., Hara, Y., Sugimoto, N., 2009. Asian dust transported one full circuit around the globe. Nat. Geosci. 2, 557-560. http://dx.doi.org/ 10.1038/ngeo583.

Uno, I., Eguchi, K., Yumimoto, K., Liu, Z., Hara, Y., Sugimoto, N., Shimizu, A., Takemura, T., 2011. Large Asian dust layers continuously reached North America in April 2010. Atmos. Chem. Phys. 11, 7333-7341. http:// dx.doi.org/10.5194/acp-11-7333-2011.

Val Martin, M., Logan, J.A., Kahn, R.A., Leung, F.-Y., Nelson, D., Diner, D., 2010. Fire smoke injection heights over North America constrained from the Terra Multi-angle Imaging SpectroRadiometer. Atmos. Chem. Phys. 10, 1491-1510.

Val Martin, M., Kahn, R.A., Logan, J.A., Kahn, R., Paugam, R., Wooster, M., Ichoku, C., 2012. Space-based observational constraints for 1-D fire smoke plumerise models. J. Geophys. Res. 117, D22. http://dx.doi.org/10.1029/ 2012JD018370.

van der Werf, G.R., Randerson, J.T., Giglio, L., Collatz, G.J., Mu, M., Kasibhatla, P.S., Morton, D.C., DeFries, R.S., Jin, Y., van Leeuwen, T.T., 2010. Global fire emissions and the contribution of deforestation, savanna, forest, agricultural, and peat fires (1997-2009). Atmos. Chem. Phys. 10, 11707-11735. http:// dx.doi.org/10.5194/acp-10-11707-2010.

van Donkelaar, A., Martin, R.V., Brauer, M., Kahn, R., Levy, R., Verduzco, C., Villeneuve, P.J., 2010. Global estimates of ambient fine particulate matter concentrations from satellite-based aerosol optical depth: development and application. Environ. Health Perspect. 118 (6), 847.

VanCuren, R.A., Cahill, T.A., 2002. Asian aerosols in North America: frequency and concentration of fine dust. J. Geophys. Res. 107 (D24), 4804. http:// dx.doi.org/10.1029/2002JD002204.

Veefkind, J.P., Boersma, K.F., Wang, J., Kurosu, T.P., Krotkov, N., Chance, K., Levelt, P.F., 2011. Global satellite analysis of the relation between aerosols and short-lived trace gases. Atmos. Chem. Phys. 11, 1255-1267.

Vermote, E., Ellicott, E., Dubovik, O., Lapyonok, T., Chin, M., Giglio, L., Roberts, G.J., 2009. An approach to estimate global biomass burning emissions of organic and black carbon from MODIS fire radiative power. J. Geophys. Res. 114, D18205. http://dx.doi.org/10.1029/2008JD011188.

Wang, J., Christopher, S.A., 2003. Intercomparison between satellite-derived aerosol optical thickness and $\mathrm{PM}_{2.5}$ mass: implications for air quality studies. Geophys. Res. Lett. 30 (21), 2095. http://dx.doi.org/10.1029/ 2003 GL018174.

Wang, J., Xu, X., Henze, D.K., Zeng, J., Ji, Q., Tsay, S.-C., Huang, J., 2012. Top-down estimate of dust emissions through integration of MODIS and MISR aerosol retrievals with the GEOS-Chem adjoint model. Geophys. Res. Lett. 39, L08802. http://dx.doi.org/10.1029/2012GL051136.

Waquet, F., Riedi, J., Labonnote, C., Goloub, P., Cairns, B., Deuze, J.-L., Tanre, D., 2009. Aerosol remote sensing over clouds using A-Train observations. J. Atmos. Sci. 66, 2468-2480.

White, W.H., 1976. Reduction of visibility by sulfates in photochemical smog. Nature 264, 735-736.

Wilcox, E.M., Lau, K.-M., Kim, K.-M., 2010. A northward shift of the North Atlantic Ocean Intertropical Convergence Zone in response to summertime Saharan dust outbreaks. Geophys. Res. Lett. 37, L04804. http://dx.doi.org/ 10.1029/2009GL041774.

Winker, D.M., Osborn, M.T., 1992. Preliminary analysis of observations of the Pinatubo volcanic plume with a polarization-sensitive lidar. Geophys. Res. Lett. 19 (2), 171-174. http://dx.doi.org/10.1029/91GL02866.

Winker, D.M., Vaughan, M.A., Omar, A., Hu, Y., Powell, K.A., Liu, Z., Hunt, W.H., Young, S.A., 2009. Overview of the CALIPSO mission and CALIOP data processing algorithms. J. Atmos. Ocean. Technol. 26, 2310-2323.

Winker, D.M., et al., 2010. The CALIPSO mission: a global 3D view of aerosols and clouds. Bull. Am. Meteorol. Soc. 91, 1211-1229.

Winker, D., Liu, Z., Omar, A., Tackett, J., Fairlie, D., 2012. CALIOP observations of the transport of ash from the Eyjafjallajokull volcano in April 2010. J. Geophys. Res. 117, D00U15. http://dx.doi.org/10.1029/2011JD016499.

Yu, H., Zhang, Z., in press. New Direction: emerging satellite observations of above-cloud aerosols and direct radiative forcing. Atmos. Environ.

Yu, H., Liu, S.C., Dickinson, R.E., 2002. Radiative effects of aerosols on the evolution of the atmospheric boundary layer. J. Geophys. Res. 107, 4142.

Yu, H., Dickinson, R.E., Chin, M., et al., 2003. Annual cycle of global distributions of aerosol optical depth from integration of MODIS retrievals and GOCART model simulations. J. Geophys. Res. 108, 4128. http://dx.doi.org/10.1029/ 2002JD02717.

Yu, H., Remer, L.A., Chin, M., Bian, H., Kleidman, R., Diehl, T., 2008. A satellitebased assessment of trans-Pacific transport of pollution aerosol. J. Geophys. Res. 113, D14S12. http://dx.doi.org/10.1029/2007JD009349.

Yu, H., Quinn, P.K., Feingold, G., Remer, L.A., Kahn, R.A., Chin, M., Schwartz, S.E., 2009a. Remote sensing and in situ measurements of aerosol properties, 
burdens, and radiative forcing in atmospheric aerosol properties and climate impacts. In: Chin, Mian, Kahn, Ralph A., Schwartz, Stephen E. (Eds.), A Report by the U.S. Climate Change Science Program and the Subcommittee on Global Change Research. National Aeronautics and Space Administration, Washington, D.C., USA.

Yu, H., Chin, M., Remer, L.A., Kleidman, R.G., Bellouin, N., Bian, H., Diehl, T. 2009b. Variability of marine aerosol fine-mode fraction and estimates of anthropogenic aerosol component over cloud-free oceans from the Moderate resolution Imaging Spectroradiometer (MODIS). J. Geophys. Res. 114, D10206. http://dx.doi.org/10.1029/2008JD010648.

Yu, H., Chin, M., Winker, D.M., Omar, A., Liu, Z., Kittaka, C., Diehl, T., 2010. Global view of aerosol vertical distributions from CALIPSO lidar measurements and GOCART simulations: regional and seasonal variations. J. Geophys. Res. 115, D00H30. http://dx.doi.org/10.1029/2009JD013364.

Yu, H., Chin, M., West, J., Atherton, C.S., Bellouin, N., Bey, I., Bergmann, D., Bian, H., Diehl, T., Forberth, G., Hess, P., Schulz, M., Shindell, D., Takemura, T., Tan, Q. 2013. An HTAP multi-model assessment of the influence of regional anthropogenic emission reductions on aerosol direct radiative forcing and the role of intercontinental transport. J. Geophys. Res. Atmos. 118. http:// dx.doi.org/10.1029/2012JD018148.

Yu, H., Zhang, Y., Chin, M., Liu, Z., Omar, A., Remer, L.A., Yang, Y., Yuan, T., Zhang, J., 2012b. An integrated analysis of aerosol above clouds from A-Train multi-sensor measurements. Remote Sens. Environ. 121, 125-131. http:// dx.doi.org/10.1016/j.rse.2012.01.011.

Yu, H., Remer, L.A., Chin, M., Bian, H., Tan, Q., Yuan, T., Zhang, Y., 2012a. Aerosols from overseas rival domestic emissions over North America. Science 337, 566-569. http://dx.doi.org/10.1126/science.1217576.

Yumimoto, K., Takemura, T., 2011. Direct radiative effect of aerosols estimated using ensemble-based data assimilation in a global aerosol climate model Geophys. Res. Lett. 38, L21802. http://dx.doi.org/10.1029/2011GL049258.

Yumimoto, K., Eguchi, K., Uno, I., Takemura, T., Liu, Z., Shimizu, A., Sugimoto, N., 2009. An elevated large-scale dust veil from the Taklimakan Desert: intercontinental transport and three-dimensional structure as captured by CALIPSO and regional and global models. Atmos. Chem. Phys. 9 , 8545-8558. http://dx.doi.org/10.5194/acp-9-8545-2009.

Yumimoto, K., Eguchi, K., Uno, I., Takemura, T., Liu, Z., Shimizu, A., Sugimoto, N., Strawbridge, K., 2010. Summertime trans-Pacific transport of Asian dust. Geophys. Res. Lett. 37, L18815. http://dx.doi.org/10.1029/2010GL043995.
Zender, C.S., Bian, H., Newman, D., 2003. Mineral Dust Entrainment and Deposition (DEAD) model: description and 1990s dust climatology. J. Geophys. Res. 108 (D14), 4416. http://dx.doi.org/10.1029/2002JD002775.

Zhang, X., Kondragunta, S., 2008. Temporal and spatial variability in biomass burned areas across the USA derived from the GOES fire product. Remote Sens. Environ. 112, 2886-2897. http://dx.doi.org/10.1016/j.rse.2008.02.006.

Zhang, J., Reid, J.S., 2009. An analysis of clear sky and contextual biases using an operational over ocean MODIS aerosol product. Geophys. Res. Lett. 36, L15824. http://dx.doi.org/10.1029/2009GL038723.

Zhang, J., Reid, J.S., 2010. A decadal regional and global trend analysis of the aerosol optical depth using a data-assimilation grade over-water MODIS and Level 2 MISR aerosol products. Atmos. Chem. Phys. 10, 10949-10963.

Zhang, J., Reid, J.S., Holben, B.N., 2005. An analysis of potential cloud artifacts in MODIS over ocean aerosol optical thickness products. Geophys. Res. Lett. 32, L15803. http://dx.doi.org/10.1029/2005GL023254.

Zhang, R., Li, G., Fan, J., Wu, D.L., Molina, M.J., 2007. Intensification of Pacific storm track linked to Asian pollution. Proc. Natl. Acad. Sci. 104 (13), 5295-5299. http://dx.doi.org/10.1073/pnas.0700618104.

Zhang, J., Reid, J.S., Westphal, D., Baker, N., Hyer, E., 2008. A system for operational aerosol optical depth data assimilation over global oceans. J. Geophys. Res. 113, D10208. http://dx.doi.org/10.1029/2007JD009065.

Zhang, Y., Fu, R., Yu, H., Qian, Y., Dickinson, R.E., Silva Dias, M.A.F., da Silva Dias, P.L., Fernandes, K., 2009. Impact of biomass burning aerosol on the monsoon circulation transition over Amazonia. Geophys. Res. Lett. 36, L10814. http://dx.doi.org/10.1029/2009GL037180.

Zhang, J., Campbell, J.R., Reid, J.S., Westphal, D.L., Baker, N.L., Campbell, W.F., Hyer, E.J., 2011. Evaluating the impact of assimilating CALIOP-derived aerosol extinction profiles on a global mass transport model. Geophys. Res. Lett. 38, L14801. http://dx.doi.org/10.1029/2011GL047737.

Zhang, Y., Yu, H., Eck, T.F., Smirnov, A., Chin, M., Remer, L.A., Bian, H., Tan, Q., Levy, R., Holben, B.N., Piazzolla, S., 2012. Aerosol daytime variations over North and South America derived from multiyear AERONET measurements. J. Geophys. Res. 117, D05211. http://dx.doi.org/10.1029/2011JD017242.

Zhao, X.-P., Laszlo, I., Guo, W., Heidinger, A., Cao, C., Jelenak, A., Tarpley, D., Sullivan, J., 2008. Study of long-term trend in aerosol optical thickness observed from operational AVHRR satellite instrument. J. Geophys. Res. 113, D07201 